\title{
Incidence and Importance of Tectonics and Natural Fluid Migration on Reservoir Evolution in Foreland Fold-and-Thrust Belts
}

\author{
F. Roure ${ }^{1}$, R. Swennen², F. Schneider' ', J.L. Faure' ', H. Ferket ${ }^{2}$, N. Guilhaumou ${ }^{3}$, \\ K. Osadetz ${ }^{4}$, P. Robion ${ }^{5}$ and V. Vandeginste ${ }^{2}$ \\ 1 Institut français du pétrole, 1 et 4, avenue de Bois-Préau, 92852 Rueil-Malmaison Cedex - France \\ 2 Afdeling Fysico-chemische Geologie, KU Leuven, Celestijnenlaan 200C, 3001 Heverlee - Belgium \\ 3 CNRS-Museum national d'Histoire naturelle, Laboratoire de Minéralogie, 61, rue Buffon, 75005 Paris - France \\ 4 Geological Survey of Canada, 3303 - 33rd Street NW, Calgary, Alberta T2L 2A7 - Canada \\ 5 Université de Cergy-Pontoise, Département des Sciences de la Terre, 5, Mail Gay-Lussac, \\ Neuville/Oise, 95031 Cergy-Pontoise Cedex - France \\ e-mail: francois.roure@ifp.fr - rudy.swennen@geo.kuleuven.ac.be - frederic.schneider@ifp.fr - j-luc.faure@ifp.fr \\ helga.ferket@geo.kuleuven.ac.be-guilhau@mnhn.fr - kosadetz@NRCan.gc.ca - robion@u-cergy.fr - veerle.vandeginste@geo.kuleuven.ac.be
}

\begin{abstract}
Résumé - Impact de la tectonique et de la migration naturelle des fluides sur l'évolution des réservoirs dans les chaînes plissées et leurs avant-pays - Nous avons utilisé ici les résultats d'études de cas réalisées dans plusieurs chaînes plissées et leurs avant-pays au moyen d'une méthodologie intégrant la géologie structurale, la pétrographie, la fabrique magnétique et les modélisations de bassin. Cette méthode permet d'identifier les paramètres critiques et les processus contrôlant l'évolution des réservoirs depuis la fin du développement de la marge passive jusqu'aux épisodes postorogéniques de collapse de l'édifice tectonique.

Les interactions fluides-roche sont exacerbées pendant les périodes de crise tectonique. La compaction tectonique est déjà active dans l'avant-pays, tandis que le développement et la réouverture de réseaux de fractures permettent de remobiliser les fluides dans les unités allochtones, d'expulser les fluides préalablement rééquilibrés des roches-réservoirs, mais aussi d'injecter de nouveaux fluides exotiques, en déséquilibre chimique, dans les drains carbonatés ou gréseux. Dans les bassins subandins, la cimentation siliceuse est ainsi dominée par les effets de la compression tectonique (raccourcissement parallèle aux couches ou LPS) dans les unités sous-charriées à proximité du front de la déformation. Le LPS est aussi suspecté de contrôler la recristallisation des mésodolomites dans l'avant-pays des montagnes Rocheuses au Canada. En revanche, la dolomitisation secondaire par processus hydrothermaux des niveaux carbonatés permet souvent une migration latérale des fluides diagénétiques le long d'horizons stratigraphiques peu pentus dans l'avant-pays, mais aussi l'échappement vertical de fluides minéralisateurs dans les réseaux de fractures ouvertes de l'allochtone. Inversement, le développement de porosité vacuolaire dans les séries carbonatées allochtones de la Cordillère nord-américaine peut s'expliquer par un refroidissement progressif du réservoir dans un système relativement clos, en liaison avec la surrection tectonique et l'érosion progressive des séries superficielles.

Les modélisations de bassin permettent d'obtenir des estimations réalistes des paléo-températures et des paléo-enfouissements atteints par un réservoir donné, valeurs qui peuvent être ensuite comparées à des paléo-thermomètres tels que les inclusions fluides ou les isotopes stables, permettant ainsi de dater de
\end{abstract}


manière indirecte les épisodes de cimentation ou de dissolution. Ces modèles de bassins fournissent aussi des vitesses d'écoulement des fluides, qui peuvent être ensuite utilisées comme conditions aux limites pour des modèles diagénétiques à l'échelle du réservoir.

Dans la nature, les interactions fluides-roche induites par l'injection tectonique de fluides exotiques sont de courte durée, ne dépassant pas le million d'années. Ces mouvements de fluides contrôlés par la tectonique constituent donc de bons analogues pour étudier les effets à long terme d'injection et de stockage de gaz acides comme le $\mathrm{CO}_{2}$ ou l' $\mathrm{H}_{2} \mathrm{~S}$ dans les réservoirs naturels. Les mêmes méthodes quantitatives, validées ici dans des études régionales, dont le but principal est l'évaluation pétrolière, constituent également des prototypes permettant déjà de fournir des valeurs de référence pour les vitesses de transfert de fluides en systèmes ouverts, qui seront de fait fort utiles pour le stockage et la surveillance de gaz acides confinés dans des réservoirs naturels.

\begin{abstract}
Incidence and Importance of Tectonics and Natural Fluid Migration on Reservoir Evolution in Foreland Fold-and-Thrust Belts - Integrated structural-petrographic-magnetic-basin modeling case studies in numerous foreland fold-and-thrust belts provided key information on the critical parameters and processes controlling reservoir evolution from the end of the passive margin phase to the post-orogenic collapse of the tectonic pile.
\end{abstract}

Fluid-rock interactions in reservoir rocks are intensified during tectonic events, as tectonic compaction in the foreland and development and re-opening of fracture systems in the allochthon help remobilizing basinal fluids, to squeeze-out host-rock buffered fluids as well as to reinject exotic fluids in reservoir sandstone or carbonate layers. For instance, quartz cementation in Sub-Andean foothills is dominantly controlled by Layer Parallel Shortening (LPS/tectonic compaction) in the footwall of frontal thrusts. LPS can also be inferred to cause in situ recrystallisation of mesodolomite in the Canadian Cordilleran Foreland Belt. In contrast, secondary hydrothermal dolomitization of limestone strata usually accounts for lateral migration in stratigraphic conduits in the foreland and for vertical migration of mineralizing fluids in open fractures in the allochthon, respectively. Alternatively, vuggy porosity observed in allochthonous carbonate strata in the North American Cordillera can also be interpreted to result from reservoir cooling operating in a dominantly closed fluid system during tectonic uplift and coeval erosion.

Basin models can provide realistic estimates of burial-temperature history that can be compared to paleo-thermometers, such as fluid inclusions or stable isotopes, and thus provide a means to determine the relative age of cementation or dissolution episodes. Basin models can also provide fluid velocities, that can be subsequently used as critical constraints on diagenetic models at reservoir scale.

Natural fluid-rock interactions induced by exotic tectonic fluids are short, no longer than one million years. As such, they constitute very good models of the long term effects of $\mathrm{CO}_{2}$ and $\mathrm{H}_{2} \mathrm{~S}$ injection and storage in natural reservoirs. The integrated quantitative appraisal approach proposed here for petroleum evaluation and reservoir prediction, also provides useful information on the overall changes in fluid flow regime and fluid velocities trough time in natural open systems, that should be used as regional boundary conditions for future reservoir storage and monitoring of acid gases in natural reservoirs.

\section{CONTENTS}

Introduction

\section{Methods Used}

1.1 Structural Analysis and Sampling of Oriented Cores and Plugs

1.2 Description of the Paragenetic Sequence and Study of Paleo-Thermometers

1.3 Reconstruction of Burial Curves and Coupled Kinematic and Thermal Modeling

1.4 Fluid Flow and Pore Fluid Pressure Reconstruction

1.5 Forward Diagenetic Modeling
2 Principal Structural Elements and Deformational Events Recorded by Sandstone and Carbonate Reservoirs in FFTB

2.1 Vertical Compaction and Bedding-Parallel Stylolites (BPS)

2.2 Early versus Late Hydraulic Fractures

2.3 Pre-Thrusting Layer-Parallel Shortening (LPS) and Development of Conjugate Vertical Joints

2.4 Syndeformational Reservoir Alteration

2.4.1 Selective Synkinematic Reactivation of Foreland Structures

2.4.2 Outer Arc Fractures

2.4.3 Synfolding Pressure-Solution 
2.4.4 Fore-Bulge versus Synkinematic Karstification

2.5 4D Evolution of the Fracture-Porosity/Permeability Characteristics from the Foreland to Frontal Anticlines

3 Major Trends of the Regional Fluid Flow and Pore Fluid Pressure Evolution in FFTB

3.1 Vertical versus Horizontal Fluid Migration in the Foreland

3.2 Hydraulic Heads and Development of Overpressures

3.3 Changes in Lateral Velocity of the Fluid Flow as a Response to Squeegee Pulse and Thrust Closure

4 LPS Controls on Reservoir Cementation

4.1 Multiphase Quartz Cementation in Sandstone Reservoirs of Sub-Andean Basins in Colombia and Eastern Venezuela

4.1.1 Origin of Silica

4.1.2 AMS and Fluid Inclusion Studies: Dating the Main Cementation Episodes

4.1.3 Stable Isotope Data and Origin of the Circulating Fluids

4.2 Mesodolomite and Syn-LPS Recrystallisation of Dolostone Reservoirs in the Foreland Belt and Basin of the Canadian Cordillera

4.2.1 Petrographic, Isotopic and Magnetic Characteristics of Mesodolomites

4.2.2 Origin of the Mesodolomite

5 Late Carbonate Dissolution and Dolomitization in an Open System

5.1 Hydrothermal Karst and Mississippi Valley Type Ore Deposits

5.2 Synkinematic Fluid Escapes and Development of the Zebra Dolomite

5.2.1 Petrographic, Isotopic and FI Data of the Zebra Dolomites

5.2.2 Origin of the Zebra Dolomites

Syn-Compressional Origin

Syn-Extensional, Post-Compressional Hypotheses

5.3 Fluid Conduits, Lateral and Vertical Mg Transfer and Development of Saddle Dolomite

6 Thrust-Related Development of Vuggy Porosity

7 Impact of Hydrocarbon Charge on Reservoir Characteristics, and How 1D and 2D-Modeling can Predict Reservoir Performance

7.1 Oil-Anhydrite Interactions and Thermo-Sulfate Reduction in FFTB

7.2 Hydrocarbon Circulation and Secondary Dissolution Along Stylolitic Planes

7.3 Successive Trapping Episodes, Deasphalting and Permeability Reduction

7.3.1 Migration Pulses and Deasphalting

7.3.2 Tectonic Uplift, Erosion and Deasphalting

7.3.3 How to Evaluate Deasphalting Risk in FFTB?
7.4 Burial Increase and the Pyrobitumen Risk in FFTB

7.5 Oil-Water Interactions and Biodegradation in FFTB

7.5.1 Foreland Tar Belts

7.5.2 Occurrence of Biodegradated Hydrocarbon Products in the Foothills

7.5.3 How to Predict the Occurrence of Biodegradated Products in FFTB Prospects?

Conclusions

\section{INTRODUCTION}

Recently, improved seismic imaging methods have led to the discovery of giant petroleum fields in deep underthrust prospects of the Sub-Andean basins and other compressional systems, renewing the corporate interest in the petroleum potential of mobile belts, where the risk of reservoir damage due to diagenesis remains the main exploration challenge. In order to identify and understand the critical parameters controlling the evolution of reservoir characteristics in foreland fold-and-thrust belts (FFTB), we have developed an integrated approach involving structural geology, petrographical description and basin modeling, thus providing a control on the burial, thermal and diagenetic evolution of individual sandstone and carbonate reservoirs, in relation to the global dynamics, tectonics and deformational history, regional fluid flow and petroleum systems.

This methodology was applied successively, and successfully, to both sandstone reservoirs in the Sub-Andean basins of Venezuela and Colombia (Figs. $1 a$ and $1 b$; BordasLeFloch, 1999; Roure et al., 2003; Toro et al., 2004), and carbonate reservoirs in the inverted Ionian Basin in Albania (Fig. 1c; Van Geet et al., 2002; Roure et al., 2004), the Sierra Madre foothills and foreland in Mexico (Fig. Id; Ferket et al., 2003 and 2004; Ortuño-Arzate et al., 2003), in the Himalayan foothills in Pakistan (Fig. le; Grelaud et al., 2002; Benchilla, 2003; Benchilla et al., in press), and the Canadian Cordilleran Foreland (Fig. If; Faure et al., 2004). However, because both the deformation and thrust fronts propagate from the hinterland toward the foreland, carbonate reservoirs initially deposited within the former passive continental margins are progressively buried in the foredeep basin, and then accreted tectonicaly into the allochthonous units of the thrust belt where they are progressively uplifted and unroofed by erosional processes (Fig. 2). Therefore, the paragenetic sequence in carbonate reservoirs currently exposed in the foothills usually record a wide range of cements, accounting for successive episodes of fluid-rock interactions in very distinct P-T conditions, but also with different types of fluids (i.e., formation and meteoric waters or hydrothermal brines). The oldest cements and deformation features such as normal faults and bedding-parallel stylolitic planes (BPS) still account for burial compaction during the former passive margin evolution in an extensional regime, 
a)
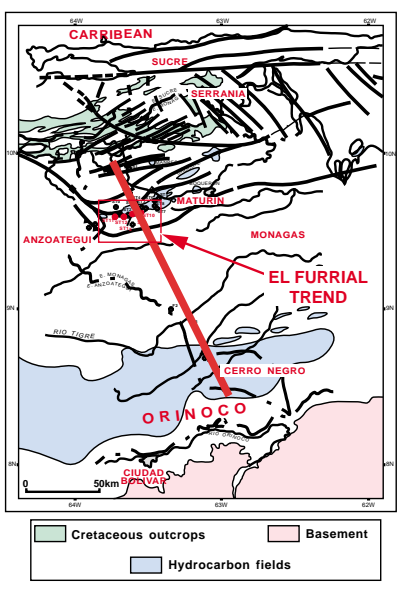

b)

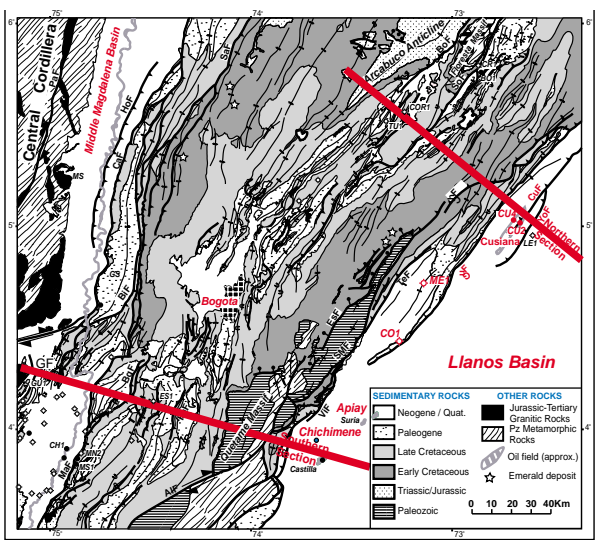

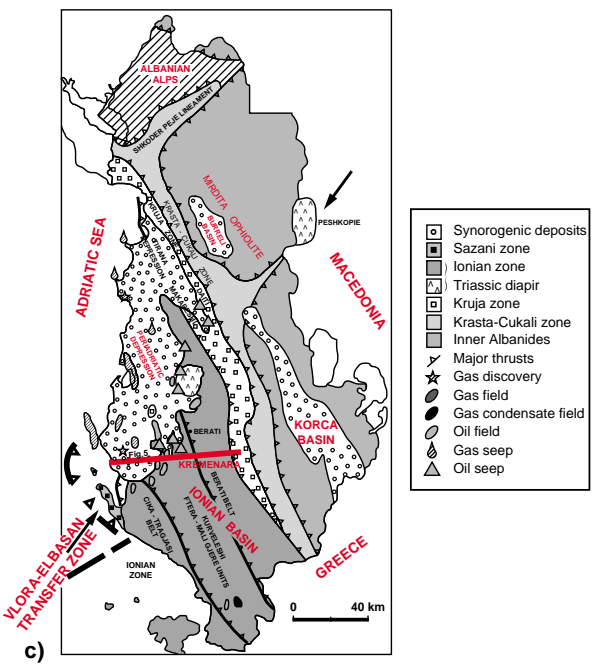

d)
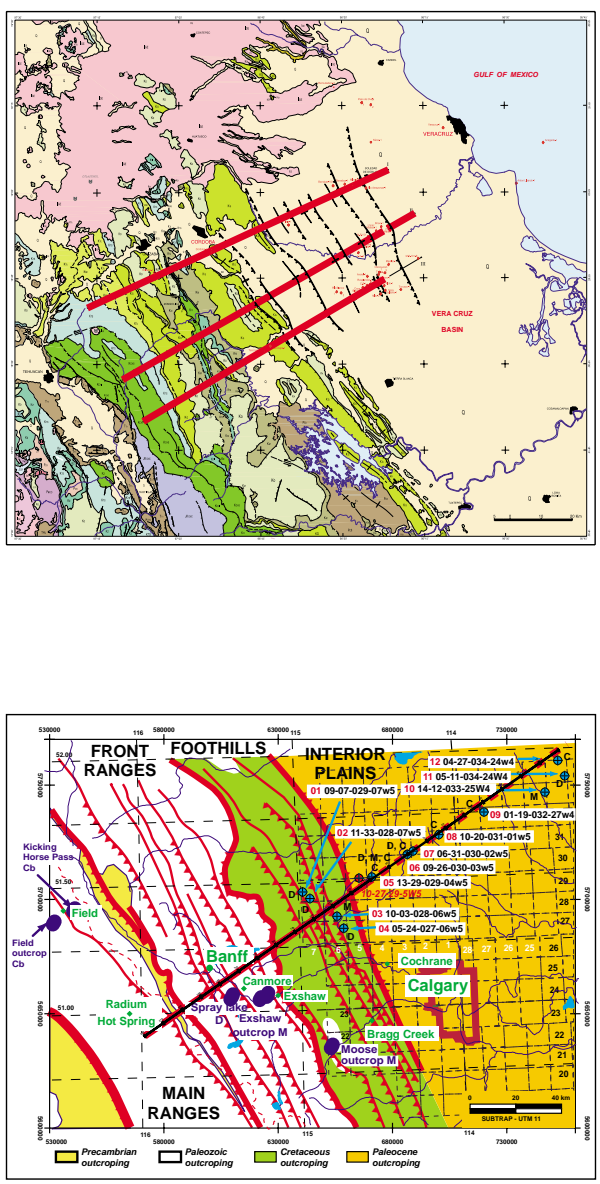

Figure 1

Location map of the main SUBTRAP regional transects: a) Eastern Venezuela SUBTRAP transect accross the foothills of the Serrania, the Maturin Basin and adjacent Orinoco foreland, aimed at the study of the Oligocene Merecure sandstone reservoir. b) Northern and southern SUBTRAP transects across the Eastern Cordillera of Colombia, aimed at the study of the Eocene Mirador sandstone reservoir in the Llanos and eastern foothills of the Cordillera (e.g., in the Caño Limon, Cusiana and Chichimene fields and Medina and Coporo wells), as well as the study of Cretaceous sandstone reservoir analogues in the Magdalena Basin and Sabana de Bogota. c) Kremenara transect accross the inverted Ionian Basin in Albania, aimed at the study of Late Cretaceous carbonate turbidite reservoir analogues. d) SUBTRAP transect across the Cordoba Platform and adjacent Veracruz Basin in the Sierra Madre foothills ans adjacent Coastal Plain of the Gulf of Mexico in Mexico, aimed at the study of Late Cretaceous platform carbonate reservoir analogues and productive Late Cretaceous deep water breccias. e) SUBTRAP transects across the Salt-Range and Potwar basins in the Himalayan foothills in Pakistan, aimed at the study of Eocene Chorgali platform carbonate reservoir in the Dakhni field and surface analogues, as well as Jurassic Datta sandstone reservoir in the Toot field and surface Cambrian Khewra sandstone reservoir analogue. f) Calgary-Banff SUBTRAP transect in the foothills of the Rocky Mountains and adjacent Alberta foreland in Canada, aimed at the study of Carboniferous carbonate reservoirs. 

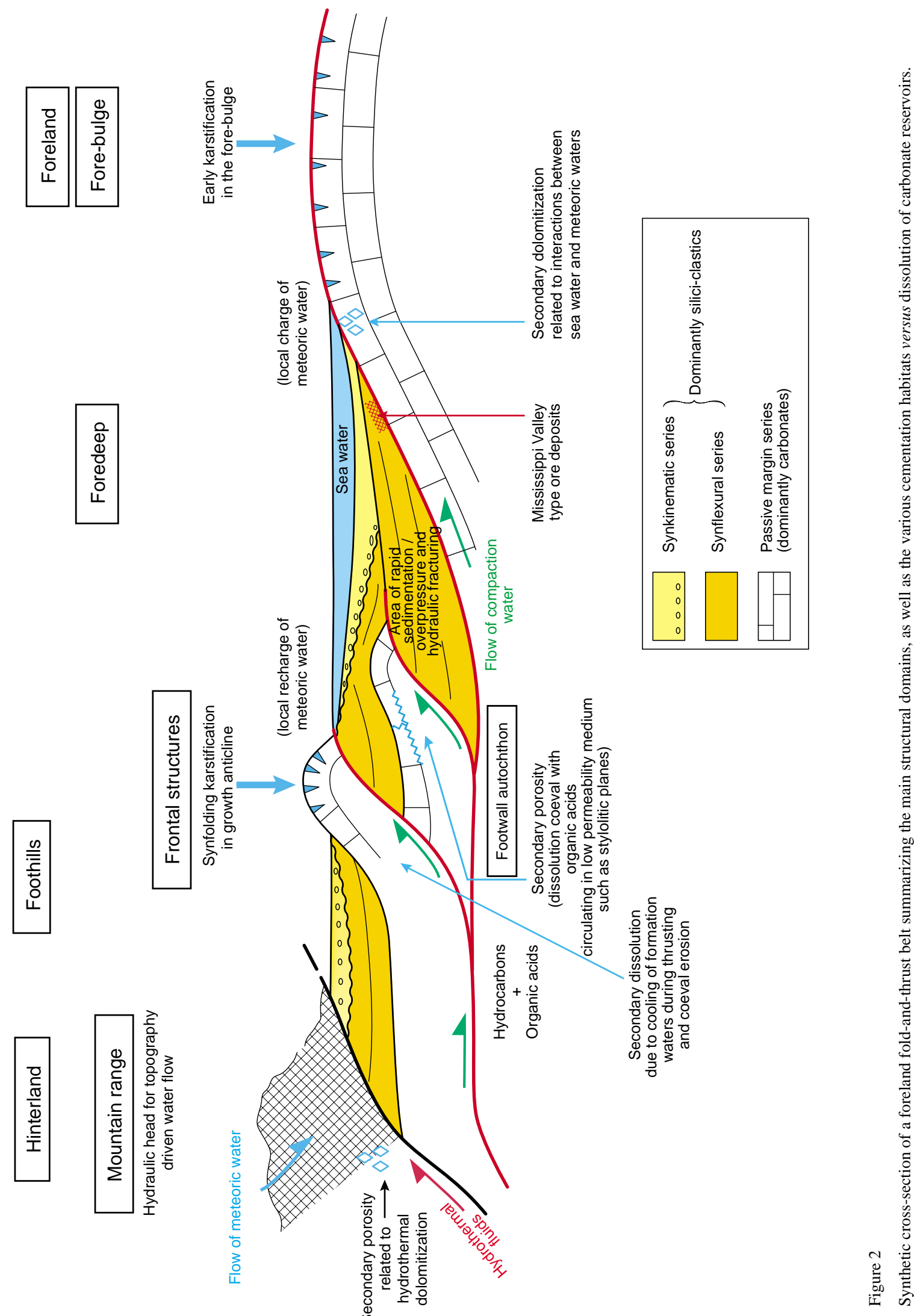
whereas only the most recent cements and deformation features such as layer-parallel stylolitic planes (LPS) are directly significant for the thrust belt evolution in a compressional regime (Figs. 2 and 3; see also Fig. 8 for complements). In contrast, most sandstone reservoirs in the Sub-Andean basins were deposited at the end of the passive margin stage, or even at the onset of the development of the foredeep basin, adjacent to the thrust front. Therefore, most diagenetic evolution of the sandstone reservoirs studied here, account mostly, apart of their early depositional history that was controlled by the paleo-environment, for synflexural and then synkinematic episodes of foreland and foothills evolution in a dominantly compressional regime.

The comparison of both carbonate and sandstone reservoirs paragenetic evolution in various thrust belts around the world was necessary to know whether or not tectonics (i.e., rock deformation and tectonically induced fluid migration) could exert a significant control on reservoir characteristics in FFTB, and whether or not these effects could be predicted and quantified. Because thermodynamics (i.e., P-T conditions) and regional fluid flow (open versus closed system, composition of the circulating fluids) have a direct impact on fluid-rock interactions, we tried also to reconstruct the complete burial and temperature history of individual reservoir units, and to characterize the main evolutionary stages of the regional fluid flow and pore fluid pressure regimes. Surprisingly, major diagenetic episodes in both carbonate and sandstone reservoirs in FFTB are usually directly linked to short-living tectonic episodes, in connection with either tectonic compaction (pressuresolution in a closed system) or fracturing (allowing rapid fluid migration and fluid-rock interactions in an open system). Results of these various case studies are summarized below, and used to illustrate the input such integrated structural-diagenetic-basin models can bring to reservoir appraisal, qualitatively (i.e. basin scale process oriented) and quantitatively (i.e. forward diagenetic simulations at the scale of individual prospects and reservoirs), for a specific time interval and a given diagenetic episode. However, because tectonically controlled episodes of fluid-rock interactions are:

- limited in time;

- localized to the vicinity of the deformation/thrust front;

- result from the rapid injection of exotic fluids into a given reservoir horizon, they are also likely to provide direct natural analogues for studying the long term effects (i.e., in the range of 100000 to $10^{6} \mathrm{y}$ ) of acid gas injection and storage in natural reservoirs.

\section{METHODS USED}

Our objective is not only to describe the present, final architecture and characteristics of a given reservoir, but also to understand its long term evolution through geological times, in relation to the global dynamics and the regional geological-tectonic evolution, as well as during successive fluid migration and fluid-rock interaction episodes. Therefore, multidisciplinary team-work is required, involving different techniques, including field observations and sampling, laboratory measurements and numerical modeling, to be applied at different scales, i.e., from the thin-section and the core, up to the prospect and even basinal scale.

\subsection{Structural Analysis and Sampling of Oriented Cores and Plugs}

Direct observation of deformation features is necessary to define the 3D architecture and relative chronology of various sets of fractures and stylolites. This is not always easy on core material, because of both recovery and orientation problems. Instead, surface reservoir analogues can usually be studied in great detail, each set of fractures or microstructures being carefully measured (both strike and dip), analysed in term of kinematic criteria (either normal, versus reverse or strike-slip motion) and a relative chronology with respect to other sets of deformation features (Fig. 3).

Oriented plugs are also sampled in individual veins and cemented fractures or stylolitic planes, thus allowing subsequent laboratory analyses such as:

- Anisotropy of magnetic fabric (AMS; Averbuch et al., 1992; Aubourg, 1999) measurements on oriented plugs helps to unravel the deformation pattern of the rock matrix, even in weakly deformed sandstones, and to provide oriented thin-sections parallel to the main principal stress axes;

- Cathodoluminescence and isotope studies on specific sets of cemented fractures and microstructures, in order to determine the nature of paleo-fluids circulating within the reservoir during a given tectonic event (Swennen et al., 2003a).

\subsection{Description of the Paragenetic Sequence and Study of Paleo-Thermometers}

Cathodoluminescence is helpful in documenting the successive episodes of cementation of a given fracture or the growth of cements within the rock matrix.

As for the description of the fracture system, it is also important to properly describe the nature of the paragenetic sequence in the rock matrix, to propose a relative chronology among its various cements, and to characterize both the composition and temperature of trapping of the paleo-fluids accounting for each episode of fluid-rock interaction. Paleothermometers such as maturity ranks of the organic matter (i.e., vitrinite reflectance measurement/Ro and Rock-Eval pyrolysis $\left(T_{\max }\right)$, fluid inclusion, stable isotopes and apatite 

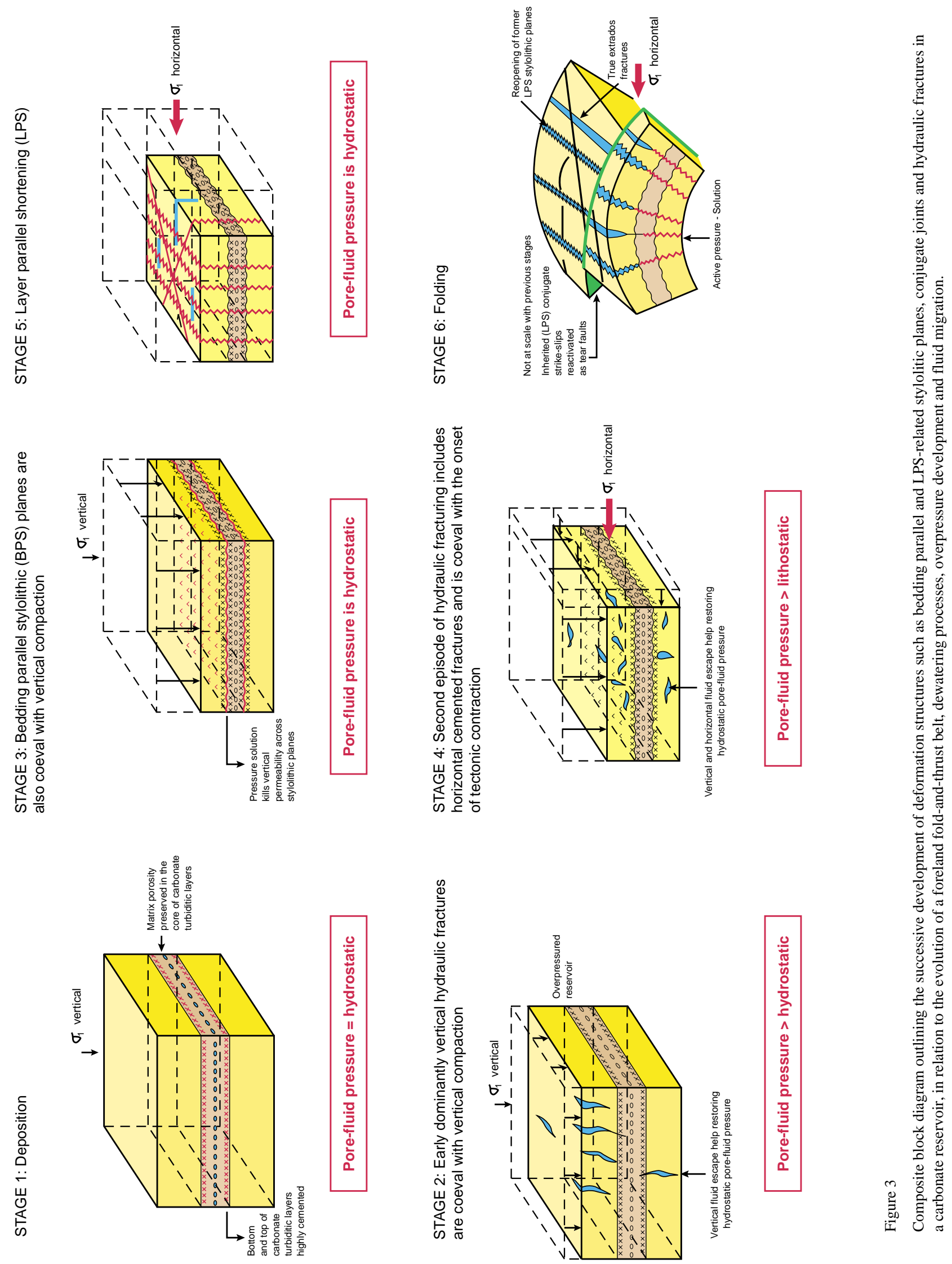
fission tracks (AFT) are combined during the same study, in addition to bottom hole temperatures (BHT), in order to get independant calibrations of the paleo-temperatures during subsequent thermal modeling (Roure and Sassi, 1995).

Fluid inclusion studies provide also direct information on the salinity of fluids circulating in the reservoir during cementation, thus providing critical information on whether a given cementation episode was coeval with the circulation of meteoric (low salinity, fresh) water, basinal/formation (marine) water, or hydrothermal brines (salinity higher than marine water) within the reservoir (Guilhaumou et al., 1994, 1996; Larroque et al., 1996).

\subsection{Reconstruction of Burial Curves and Coupled Kinematic and Thermal Modeling}

The relative chronology among cements and fractures is provided by microtectonic analysis and description of the paragenetic sequence. However, the absolute dating of a given episode of fluid-rock interaction is never obvious, due to the overall composition of the mineralogical assemblage in the sediments, which usually prevents the use of radiometric geochronology.

Therefore, we rely on the combination of paleo-thermometric measurements in the cemented reservoirs and on results of thermal modeling calibrated against the maturity ranks of organic matter. Dates are obtained directly by comparing the paleo-temperatures measured in a given mineral with the temperature versus time curves computed for the overburden (Bordas-Le Floch, 1999; Roure et al., 2003).

Classic backstripping techniques allow burial history reconstruction of the former passive margin succession, but forward kinematic modeling coupling thrust motion with synorogenic sedimentation and erosion processes is required to provide more realistic burial curves for reservoir units localized in such tectonically complex areas as foothills and fold-and-thrust belts. Thermal modeling is then performed, assuming purely conductive heat transfers with 1 or $2 \mathrm{D}$ basin modeling tools such as Genex and Thrustpack. The detailed description of such coupled Thrustpack kinematic and thermal modeling performed along these Venezuelan, Colombian, Albanian, Mexican, Pakistani and Canadian transects is published elsewhere (Grelaud et al., 2002; Ortuño-Arzate et al., 2003; Roure et al., 2003, 2004; Faure et al., 2004; Toro et al., 2004).

\subsection{Fluid Flow and Pore Fluid Pressure Reconstruction}

The kinetics of a given cementation episode due to fluid-rock interaction is dependent on temperature. Alternatively, the volume of cement generated during a given time interval (i.e., a given tectonic episode) is also dependent on the chemistry and velocity of the circulating fluids when the reservoir acts as an open system. Seemingly, values of the pore fluid pressure have a direct impact on the mode of deformation, thus allowing either the coupling or decoupling of sedimentary layers with respect to the underlying substratum when subjected to horizontal tectonic stress, overpressure ultimately accounting for a drecrease or delay of compaction.

Fortunately, computation of the velocity of circulating fluids and reconstruction of the pore fluid pressure evolution of the reservoir can now be performed in $2 \mathrm{D}$, not only across passive margins and extensional basins using commercial tools such as BasinMod or Temis, but also in tectonically complex areas such as foreland fold-and-thrust belts, using new model prototypes such as CERES. For the current project, we used the resulting sections derived from the $2 \mathrm{D}$ forward kinematic modeling (templates of the intermediate geometries of the fold-and-thrust structures and erosional surfaces taken from the Thrustpack sections) as an input for further fluid flow modeling with CERES. Detailed description of the CERES fluid flow modeling along these Venezuelan and Canadian transects has been already published elsewhere (Schneider, 2003; Faure et al., 2004; Schneider et al., 2004).

\subsection{Forward Diagenetic Modeling}

Once a given diagenetic event has been dated and its duration estimated, it becomes possible to compute the amount of cement generated in the reservoir during this episode (or the increase of porosity in case of a dissolution event), provided we know the kinetics of this specific fluid-rock transformation, the average temperature of the reservoir during this time interval, and the composition and velocity of the circulating fluids, in the case where the reservoir is an open system (Le Gallo et al., 1998).

Because 1D numerical tools such as Diaphore can work with a significant number of mineralogic phases, forward diagenetic simulations are currently used to test a number of hypotheses regarding the boundary conditions of fluid-rock interactions at reservoir scale (i.e., closed versus open system, chemical composition of the exotic fluids versus mineralogical composition of the rock matrix). The results of these simulations and further iterations are then compared with the actual petrographic observations in thin-sections.

Instantaneous temperatures and fluid flow velocities derived from basin-scale Thrustpack or CERES modeling for a given tectonic episode have been used as input data for more local reservoir-scale diagenetic modeling of quartzcementation in eastern Venezuela, and hydrothermal dolomitization in the Canadian Rockies. Note that the incremental deformation applied to basin-scale models such as Thrustpack and CERES is dependent on the duration of thrust belt development, and also on the duration of previous passive margin evolution, i.e., from the time of deposition of the reservoir up to Present (i.e., $300 \mathrm{Ma}$ for Mississippian carbonates in Rockies, $60 \mathrm{Ma}$ for the Mirador reservoir 
in Colombia, against only $30 \mathrm{Ma}$ for the Merecure reservoir in Venezuela). Most modeling effort is focused on synkinematic episodes. Typicaly, time intervals between 1 and $5 \mathrm{Ma}$ have been used between two successive steps of the kinematic simulation in both Venezuela and Canada, which is a maximum value for the duration of individual thrust controlled fluid flow and diagenetic episodes. Instead, forward diagenetic simulations were performed with much shorter incremental time intervals, starting from 1000 and 10000 years, up to 100000 years and $1 \mathrm{Ma}$, keeping both temperature and fluid flow velocities constant for these relatively short intervals compared to the ones used for the basin-scale modeling.

\section{PRINCIPAL STRUCTURAL ELEMENTS AND DEFORMATIONAL EVENTS RECORDED BY SANDSTONE AND CARBONATE RESERVOIRS IN FFTB}

Sandstone reservoirs are commonly located within, or at the base of, the foredeep basin succession, with the best reservoir lithologies being the coarse quartz dominant clastics within a foreland craton provenance, as opposed to the arc-derived clastics, which usually contain more feldspar and lithic grains. Aside from their initial detrital mineralogy, sandstone reservoir characteristics result from successive episodes of burial in the foredeep, and their subsequent deformation and diagenesis during tectonic accretion in the foothills.

In contrast, most carbonate reservoirs preserve a much longer and complex diagenetic history, as they were commonly deposited during the former passive margin interval. Consequently, early diagenetic episodes linked to changes in sedimentary setting, i.e. facies controlled as well as changes in sea-level, rift related extensional deformation, uplift and exposures, can usually still be identified in these lithologies, in addition to the overprint of secondary deformation and diagenetic episodes related to their syntectonic burial in the foredeep and subsequent tectonic accretion in the foothills (Sassi and Faure, 1996).

The study of cemented fractures is informative regarding the nature of the fluids circulating during a given tectonic episode. Alternatively, knowing when fractures were open and acted as vertical conduits to fluids is also critical for predicting when fluid-rock interactions could occur. Our discussion below focuses only on the synflexural and syncompressional deformation features of the reservoirs (Fig. 3).

\subsection{Vertical Compaction and Bedding Parallel Stylolites (BPS)}

Bedding parallel stylolites (BPS) are common structures in carbonate reservoirs, but they are also locally present in sandstones, e.g., in the Cretaceous siliciclastic succession at Moose Mountain in the Canadian Foothills. BPS planes damage the porosity-permeability of the rock matrix by causing both compaction and cementation. BPS are also potential conduits for subsequent fluid migration, which commonly is the cause of dissolution in nearby strata and of the development of secondary porosity along the stylolites. Several processes are likely to enhance the opening of BPS after their development, i.e.:

- Maturation of organic material concentrated along the seams and generating acidic fluids which may dissolve the adjacent matrix (Harrison and Thyne, 1991).

- Bedding-parallel shear during folding and thrusting and the inherent roughness of these surfaces.

- Splitting due to pressure reduction after tectonic uplift and erosion, the latter mainly affecting outcrop examples.

The development of BPS and the subsequent eventual evolution of enhanced matrix porosity along these stylolites are lithology-dependent:

- In the upper Cretaceous to Eocene pelagic formation of the Ionian basin in Albania, only the dominantly micritic carbonate facies displays well-developed stylolites and good secondary porosities related to BPS. Pressuresolution related to vertical compaction is less welldeveloped in coarser grained turbidite beds and remains more diffuse in debris flows where each individual clasts become the site of indentation and stylolitization. However, the secondary porosity developed along the stylolites may contribute to bulk matrix porosity (Van Geet et al., 2002; Swennen et al., 2004).

- In the Salt Range-Potwar basin in Pakistan, BPS can constitute important conduits to fluids in marine Permian limestones where individual stylolitic peaks up to $10 \mathrm{~cm}$ long develop around coarse lithoclasts where they are the source of good secondary porosity. In contrast to the Permian carbonates, Eocene reservoirs in Pakistan have a high shale content and shaley interbeds are common. This prevents the development of penetrative pressure-solution at the boundaries of carbonate beds in these strata.

The minimum burial depth for BPS to develop is assumed to be $800-1000$ m (Machel, 1990; Railsback, 1993). Only relatively pure carbonate formations are likely to develop secondary porosity along these deformation structures, which result in good permeabilities along bedding.

\subsection{Early versus Late Hydraulic Fractures}

Paleo-hydraulic fracturing, although difficult to recognize, can be inferred locally from the occurrence of breccia-veins, sedimentary dykes, clustered cyclic microveins and/or compound veins. Fluid inclusion pressure-calculations give a stronger indication, but unfortunately vein-cements do not always possess suitable inclusions (Ferket et al., 2004). Hydraulic fracturing and brecciation have been documented 
locally, in the vicinity of major normal faults, where they provide a conduit for the progressive vertical escape of overpressured fluids within a dominantly extensional stress regime when the maximum principal stress is vertical.

In compressional stress regimes, when the maximum stress is horizontal, it is also possible to recognize hydraulic fractures along decollement surfaces. Examples include the sole thrust of the accretionary wedges in both Sicily and the Southern Apennines (Roure et al., 1991; Larroque, 1993; Larroque et al., 1996). Breccia-veins and indications for overpressures during the compressional stage are found also in Cretaceous carbonate reservoirs in eastern Mexico (Ferket et al., 2004). Hydraulic fractures can develop parallel to the bedding planes, indicating pore fluid pressures that possibly exceeded the lithostatic load. Unfortunately, these hydraulic fractures are generally cemented and they are no longer conduits for modern fluid migration. Other features indicating episodic fluid release are "crack-seal" fractures (Fig. 3) recognized in all the foreland fold-and-thrust belt settings studied. This cyclic behavior can be caused by variations in local stresses or by oscillations in fluid pressure (Simpson and Richards, 1981).

Nonetheless, cross-cutting relationships at outcrop scale or in thin-sections demonstrate that these structures may develop prior to BPS (Ferket et al., 2004), but that they develop more generally after BPS and before the formation of the LPS structures (Van Geet et al., 2002). As such, hydraulic fractures are very informative regarding dewatering processes operating in FFTB, and they demonstrate that overpressures can reduce the effects of both vertical and horizontal compaction in sandstone and carbonate reservoirs. Due to increasing tectonic stress and lowered differential stress in the early compressional stage, increased fluid pressures are required to explain extensional fracturing (hydraulic fracturing). The veins, formed before LPSstylolite development, are interpreted to originate from a caterpillar-type of LPS-deformation. With the onset of tectonic contraction, formation waters are first driven out and, if impermeable barriers are present, overpressures build up, which may lead to hydraulic fracturing. With increasing tectonic stress, the reservoir rock is compacted and LPS structures may develop. The deformation is progressive from hinterland to foreland and may result in a cyclic process of dewatering with hydraulic fracturing and subsequent penetrative LPS deformation (Ferket et al., 2004).

\subsection{Pre-Thrusting Layer Parallel Shortening (LPS) and Development of Conjugate Vertical Joints}

Conjugate strike-slip faults with incipient pressure-solution along slickensides and stylolitic planes perpendicular to bedding are well documented in most carbonate foothills outcrops, especially where the carbonates are fine grained (Alvarez et al., 1976, 1978; Geiser and Sansone, 1981). In an example of salt-detached folds from the South Pyrenees, Sans et al. (2003) derive a LPS shortening estimated at between 16 and 23\% greater than the folding related shortening. Late-stage secondary porosity commonly develops along sub-vertical LPS features, making them efficient conducts for vertical fluid migration in most carbonate reservoirs (Van Geet et al., 2002; Ferket et al., 2004).

Joints and related LPS structures are generally interpreted to develop prior to folding, when the bedding is still subhorizontal. However, some authors (Averbuch et al., 1992) have shown that LPS occurs more frequently near fault ramps, suggesting either a peculiar concentration of the LPS where the structure will develop subsequently, or that the formation of LPS extends into the early stages of folding. Some models, like the trishear folding model (Erslev, 1991; Hardy and Ford, 1997; Allmendinger, 1998; Grelaud et al., 2002), assume that a thickening resulting from a bedding parallel pure shear occurs in the early stages of folding in the forelimb as well as above the ramp (backlimb) of fault bend folds (see Fig. 8 for schematic description).

These are eventually reactivated during subsequent folding episodes where they can contribute to the formation of secondary porosity. LPS surfaces are likely to act as localized vertical conduits to fluids, and are frequently filled with hydrocarbons (Ferket et al., 2003a and 2003b, 2004; Dewever et al., in press). Although such LPS structures remain relatively diffuse in massive platform carbonates, they are commonly associated with orthogonal tension joints that form parallel to the main horizontal stress. These joints can also contribute to vertical fluid migration, if they escape cementation, provided that their present orientation is favourably oriented with respect to the modern stress regime.

Craddock and Van der Pluijm (1989) have shown the large scale effects of the deformation in the Paleozoic AppalachianOuachita foreland, where the mechanical twinning in calcite recorded a horizontal shortening due to the development of the Alleghanian thrust system. This result was confirmed by Sun et al. (1993), Cioppa et al. (1999, 2000, 2001, 2003 and 2004), Lewchuk et al. (1998), who measured typical LPS magnetic fabric and suggested spatial and temporal relationship between the development of internal deformation, the acquisition of chemical remagnetization and the circulation of orogenic fluids.

\subsection{Syndeformational Reservoir Alteration}

\subsubsection{Selective Synkinematic Reactivation of Foreland Structures}

The current aperture and permeability of microstructures that developed during the foreland evolution are controlled by numerous parameters, including: 
- their initial cementation and secondary porosity characteristics;

- their current position in the folded structures (i.e., in the outer arc or instead in an inner arc position, in the forelimb or in the backlimb of the fold; Sassi and Faure, 1996; Mercier et al., 1997; Frizon de Lamotte et al., 1997, 1998; Saint-Bezar et al., 1998; Grelaud et al., 2000);

- their orientation and spacing relative to the modern principal stresses (Guiton, 2001; Guiton et al., 2003a and 2003b);

- the amount of tectonic uplift and coeval erosion, resulting in a cooling of formation waters and local development of secondary porosity (i.e., synkinematic development of vuggy porosity, Swennen et al., 2002; see also Section 6 of this paper).

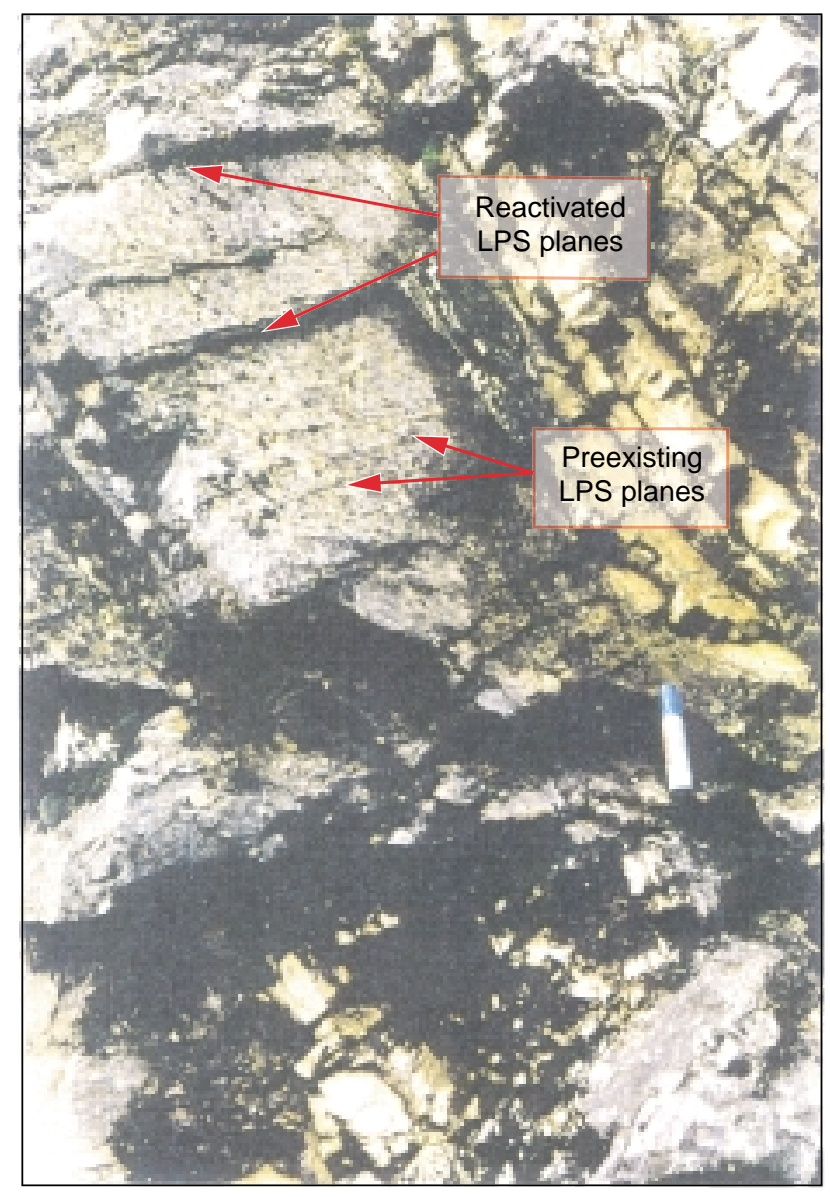

Figure 4

Late Cretaceous carbonate outcrop along the eastern flank of the Kremenara anticline (Ionian Basin, Albania, see location in Figure 1c), outlining the selective reactivation of LPS joints in the outer arc of the fold.

Among a specific family of microstructures, characterized by a given strike and dipping atitude and spacing, only a fraction of the pre-existing structures are commonly reactivated, indicating that the density and spacing of reactivated structures are more diffuse than those inherited from the foreland autochthon. This is well documented for the synfolding reactivation of LPS planes in the upper Cretaceous carbonates of the Kremenara anticline in the Ionian basin in Albania (Van Geet et al., 2002; Fig. 4):

- the initial spacing of inherited structures is approximately $5 \mathrm{~cm}$. Most of the LPS planes remain cemented and useless in terms of fluid transfer and secondary porosity;

- in contrast, the spacing of reactivated planes is approximately $20 \mathrm{~cm}$. A quarter of the currently open and reactivated LPS planes are open outer arc high-angle fissures with a vertical offset of 2 to $5 \mathrm{~cm}$.

\subsubsection{Outer Arc Fractures}

Reactivated LPS structures observed in Albania and Pakistan mimic the expected distribution of incipient outer arc structures (van Geet et al., 2002; Benchilla, 2003), which challenges the previous interpretation of similar open fracture sets in other foothills settings, especially where no nearby footwall analogue was studied to determine the pre-folding distribution of microstructures.

Therefore, a good understanding of the kinematics and modes of folding is required to specify or predict the timing and distribution of individual outer arc structures, especially when there are indications for a progressive migration of fold hinges (Mercier et al., 1997; Saint-Bezar et al., 1998).

Regardless of whether these outer arc features are initiated during folding episodes (Frizon de Lamotte et al., 1997, 1998; Grelaud et al., 2000) or progressively reactivated preexisting LPS joints (this paper; Fig. 4), they contribute to the secondary porosity and enhanced vertical permeability, thus allowing rapid vertical fluid migration near the crest of anticlines. However, this is not always a benefit in terms of the total-production characteristics of the reservoir, as it often results, as in Albania, a geometry that contributes to early water production and lower petroleum recovery factors.

\subsubsection{Synfolding Pressure-Solution}

Another point relates to the occurrence and distribution of localized pressure-solution surfaces that develop in an inner arc position, at a high-angle to the bedding, in response to the curvature of folded beds (Mercier et al., 1997; Saint-Bezar et al., 1998; Fig. 3, stage 6). Unlike the bedding-parallel and LPS stylolitic planes, which developed in the foreland, these microstructures are very localized in the inner arc portion of kinks and folds. Often, they are not interconnected at the scale of a bed, which isolates them from any further role in vertical or lateral fluid migration. In contrast, they contribute to reservoir damage due to increased compaction and cementation. 


\subsubsection{Fore-Bulge versus Synkinematic Karstification}

Karstification of carbonates commonly occurs at the end of the passive margin stage, when the foreland is uplifted and exposed in a fore-bulge position, prior to its renewed subsidence and burial in the foredeep basin (i.e. in the Potwar basin in Pakistan; Benchilla, 2003; and in the Cordoba Platform Mexico, Ferket et al., 2003, 2004; Ortuño-Arzate et al., 2003; Fig. 2). Alternatively, karstification can occur synchronously with folding and thrusting at the crest of growth folds, thus post-dating the episodes of maximum burial in the foredeep basin (i.e., in the Kremenara anticline in the inverted Ionian Basin in Albania, van Geet et al., 2002; Fig. 2). Both early and late meteoric karsts develop along former rock heterogeneities such as paleo-sols, paleo-karsts, bedding planes, stylolites and fractures. Its intensity is dependent on the relief created and the time-period during which meteoric water infiltration may occur. Many of these karsts conduits become infilled or cemented and are thus no longer important for porosity and permeability enhancement. However, since these strata are often reactivated by late stage diagenesis (e.g., hydrothermal karstification; Nielsen et al., in press), they may become important fluid conduits. In the Cordoba Platform-Veracruz Basin (Mexico), exposure during the Campanian led to erosion and karstification of the upper Cretaceous platform strata. Some of these preLaramide karst systems show oil-stains indicating that they served as conducts for oil migration (Ortuño-Arzate et al., 2003; Ferket et al., 2003, 2004).

\subsection{D Evolution of the Fracture- Porosity/Permeability Characteristics from the Foreland to Frontal Anticlines}

Major tear faults are likely to control the current compartimentalization of both sandstone and carbonate reservoirs at seismic and regional scales, i.e. at the scale of an anticline several kilometers long. Frequently, tear fault systems result from a selective reactivation of foreland structures, that originated as pre-existing normal faults, or eventually one of the sets of LPS conjugate strike slip systems. As such, tear faults provided a protracted control on fluid migration, which is likely to progressively modify the overall reservoir characteristics of nearby strata, from their initial development within the foreland autochthon, until their current remobilization within the allochthon. However, their precise influence of the hydrodynamics of a given prospect is not easily documented without access to production data.

In contrast, interconnections between the rock matrix and fracture systems are easier to document at outcrop and reservoir scales. We have summarized the main results of our field observations in the block diagrams of Figure 3. This figure displays the progressive evolution of the total porosity and permeability of fracture systems and stylolitic planes, starting from the foreland, to the footwall of the frontal thrust, and finally in the accretionary wedge carbonate reservoirs and anticlinal prospects.

These features help understanding which type of microstructure is likely to enhance horizontal or vertical fluid migration during each of the successive tectonic episodes. Clearly, only the last, current stage would be of direct interest for the modeling of production and injection behaviour, but other features, formed in earlier time intervals are also important in order to understand and predict the petrophysical properties of the reservoir rocks, as these can have influenced fluid migration and diagenesis in the vicinity of previously open microstructures. Furthermore they may become reactivated. In a number of studies, we could document the evolution of fluid migrations through the fracture system, using crosscutting relationships between these different sets of structural elements (Van Geet et al., 2002; Ortuño-Arzate et al., 2003; Ferket et al., 2003a and 2003b, 2004).

\section{MAJOR TRENDS OF REGIONAL FLUID FLOW AND PORE FLUID PRESSURE EVOLUTION IN FFTB}

Local core or outcrop observation and the distribution of cemented versus open fractures provide information on whether the reservoir acted as a closed or an open system to fluids. However, basin-scale modeling is also required to get a more regional understanding of fluid migration, and to know both at what time tectonic stress or rising topography of the foothills are likely to have reorganised previous circulation regimes inherited from the former passive margin, and the composition of the circulating fluids (marine fluids versus meteoric water or hydrothermal brines).

Numerous papers have described the fluid flow regime associated with dewatering processes in modern accretionary wedges and seismically active areas (Moore et al., 1991; Muir Wood, 1994; Henry, 2000), as well as paleo-fluid flow in Paleozoic and Alpine orogens (Oliver, 1986; Yao and Demicco, 1995, 1997; Muchez et al., 1995, 2000, 2002; Travé et al., 1998, 2000 and 2004; Roure and Swennen, 2002; Swennen et al., 2003a, 2004). Numerical simulations have been used recently to account for the topographic gravity driven regional fluid flow currently observed in foreland foldand-thrust belts (Garven, 1985; Ge and Garven, 1989, 1992 and 1994; Nesbitt and Muehlenbachs, 1994; Bachu, 1999).

For the first time however, we could use a coupled kinematic-basin modeling tool developed at IFP, namely CERES (Schneider et al., 2002, 2004; Schneider, 2003), to reconstruct both the fluid flow and pore fluid pressure regimes along two regional transects across the Eastern Venezuelan foothills and the Canadian Rockies between Banff and Calgary, taking into account not only the modern topography, but also the former thrust kinematics and competing sedimentation and erosion processes. 
When reconstructing the pressure regime and the fluid flow history in the Oligocene sandstone reservoir of the El Furrial structure in Eastern Venezuela and in the Mississippian dolomites of the Canadian Foothills, two critical periods can be identified, the first at the beginning of the flexuring deformation, and the second time when thrusting was active (Schneider, 2003).

Thrust kinematics are no longer active in the Canadian Foothills, the frontal thrusts being dated as late Cretaceous until Paleocene-Early Eocene in age, whereas folding and thrust deformation lasted from the Neogene until PlioQuaternary times along the El Furrial-Pirital thrusts in Eastern Venezuela. Noteably, current fluid flow regimes are also quite distinct in Eastern Venezuela and the Canadian Rockies, fluid flow being exclusively topographic gravity driven in the North American Cordillera, whereas it is still partly controlled by thrust motion and layer parallel shortening in the still currently tectonically active Caribbean thrust belt (Roure et al., 1994).

\subsection{Vertical versus Horizontal Fluid Migration in the Foreland}

Before the onset of thrust loading and the development of the foreland basin, fluids within reservoir rocks are usually close to chemical equilibrium with the sediments. Basinal fluids are continuously expelled toward the surface during sedimentary burial, coeval compaction and dewatering, unless a local disequilibrium occurs between the rates of sedimentation and compaction, and the resulting values of vertical permeability. As mentioned previously, overpressure and hydraulic fracturing can develop locally beneath efficient seals during these early stages of basin evolution, even before the onset of thrust belt development.

Subsequent episodes of thrust loading will induce a regional tilting and progressive development of the foreland monocline with the deposition of synflexural sediments. Fluids are then rapidly expelled laterally from the foredeep area toward the foreland during a so-called "squeegee" episode (Machel and Cavell, 1999). In the footwall of the frontal thrust and in the foredeep basin, fluid flow is channelized along the stratification of reservoir conduits where it can reach velocity of tens of kilometers per Ma. The squeegee episode of fluid expulsion stops when the given reservoir unit is detached from the foreland autochthon and becomes tectonically accreted into the frontal anticline (Fig. 5).

\subsection{Hydraulic Heads and Development of Overpressures}

From the time of deposition to the onset of reservoir tilting, overpressure is mainly controlled by the dewatering process associated to compaction, the maximum principal stress being then vertical. During subsequent episodes of compression, maximum principal stress becomes horizontal in the foredeep basin. Layer parallel shortening (LPS), increase of sedimentation rate in the foreland and tectonic loading in the hinterland may change the previous equilibrium toward an increased overpressure.

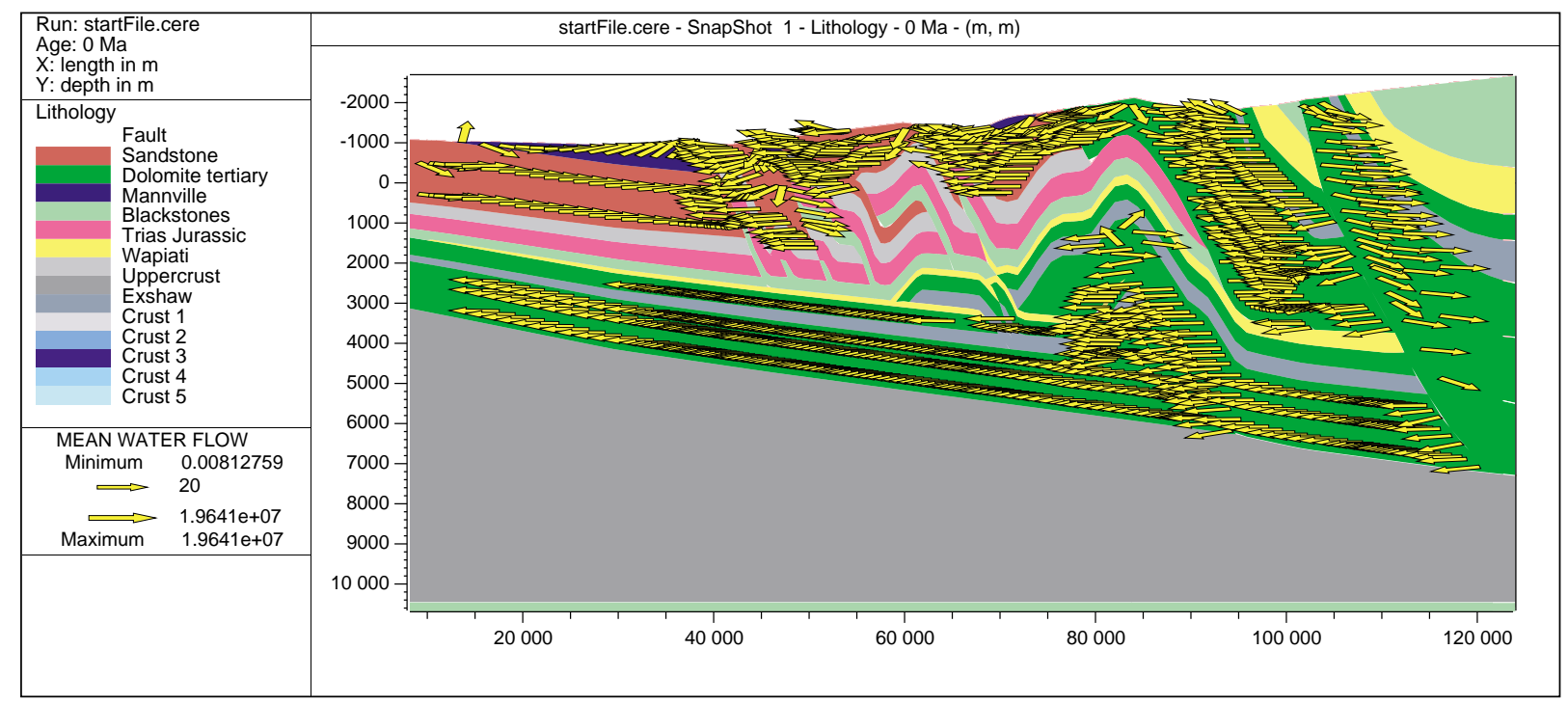

Figure 5a

CERES fluid flow simulations along the Banff-Calgary SUBTRAP transect in the Canadian Rockies and adjacent foreland. See Figure 1f for location. Present-day fluid flow pattern along the transect, as computed by CERES. Notice the forelandward fluid escape in the footwall autochthon (a); the reverse flow observed in shallow Cretaceous sandstones of the foreland (b); and convection of meteoric water in the hinterland (c). 


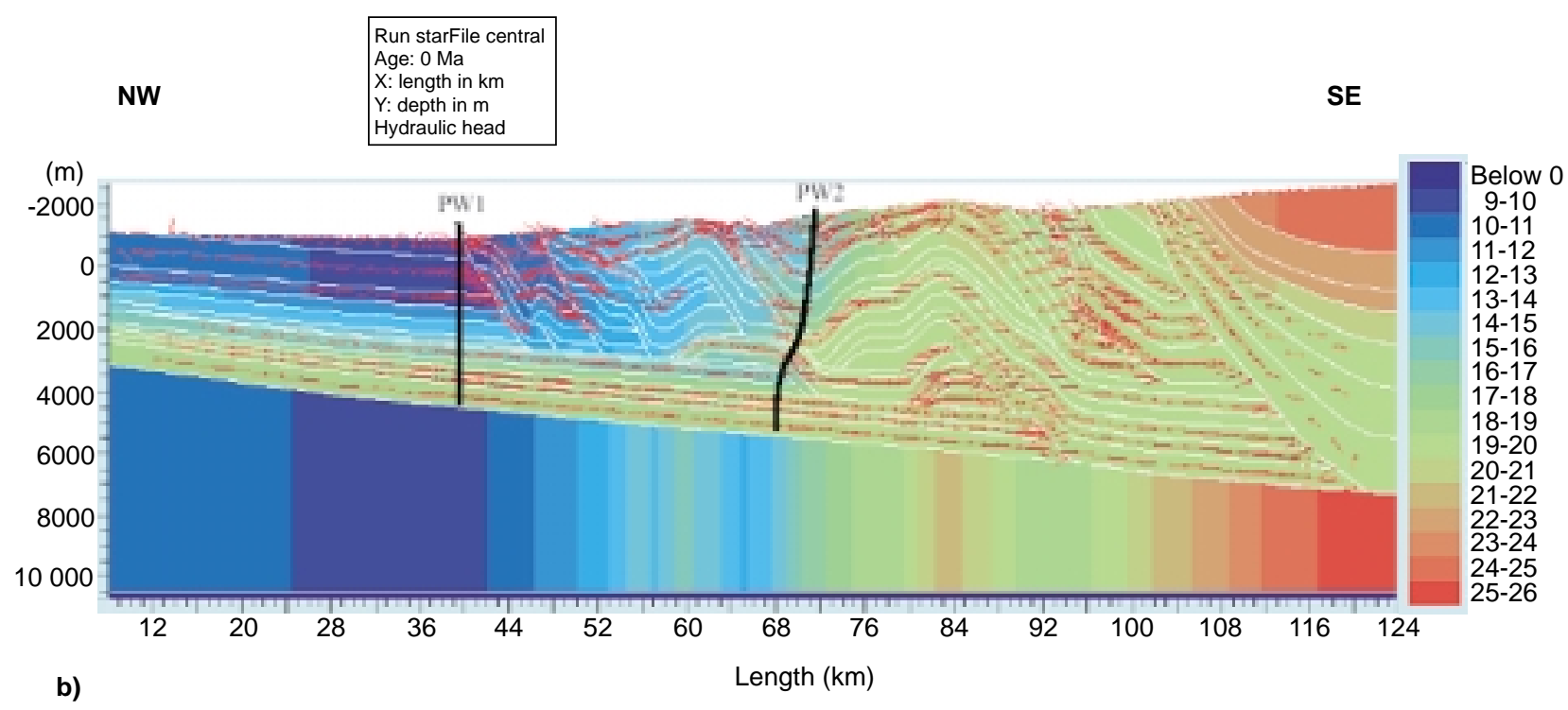

Figure $5 b$

Present distribution of overpressures across the transect.

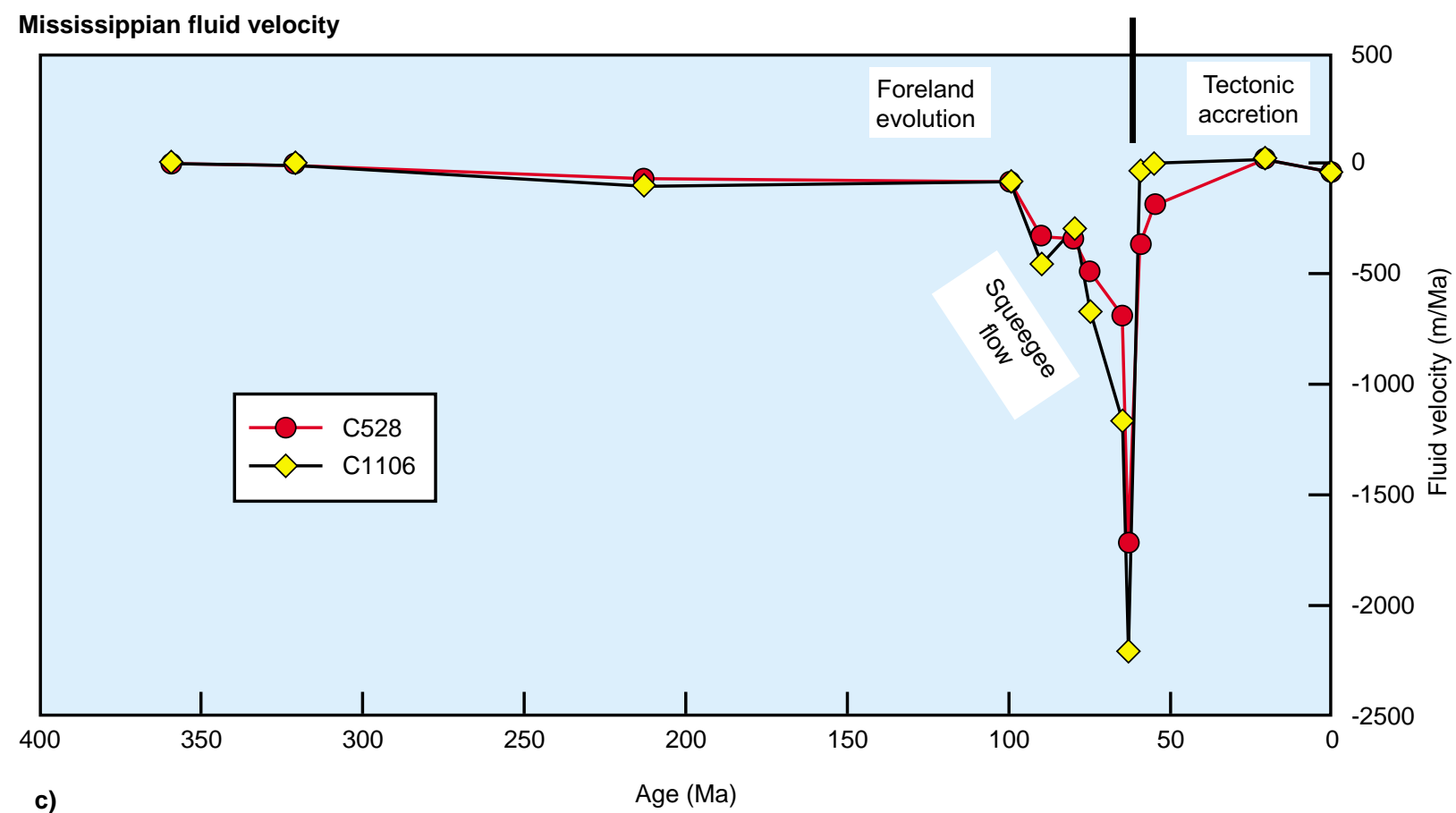

Figure 5c

Fluid flow velocity versus time diagram in Mississippian reservoirs for two model wells (PW1 and PW2) currently located in the foothills. Notice the rapid changes inferred in fluid velocity in Mississippian reservoirs when entering in the foothills area (squeegee episode), and the subsequent closure of the system after thrust displacement (for further detail, see Schneider, 2003, and Faure et al., 2004). 

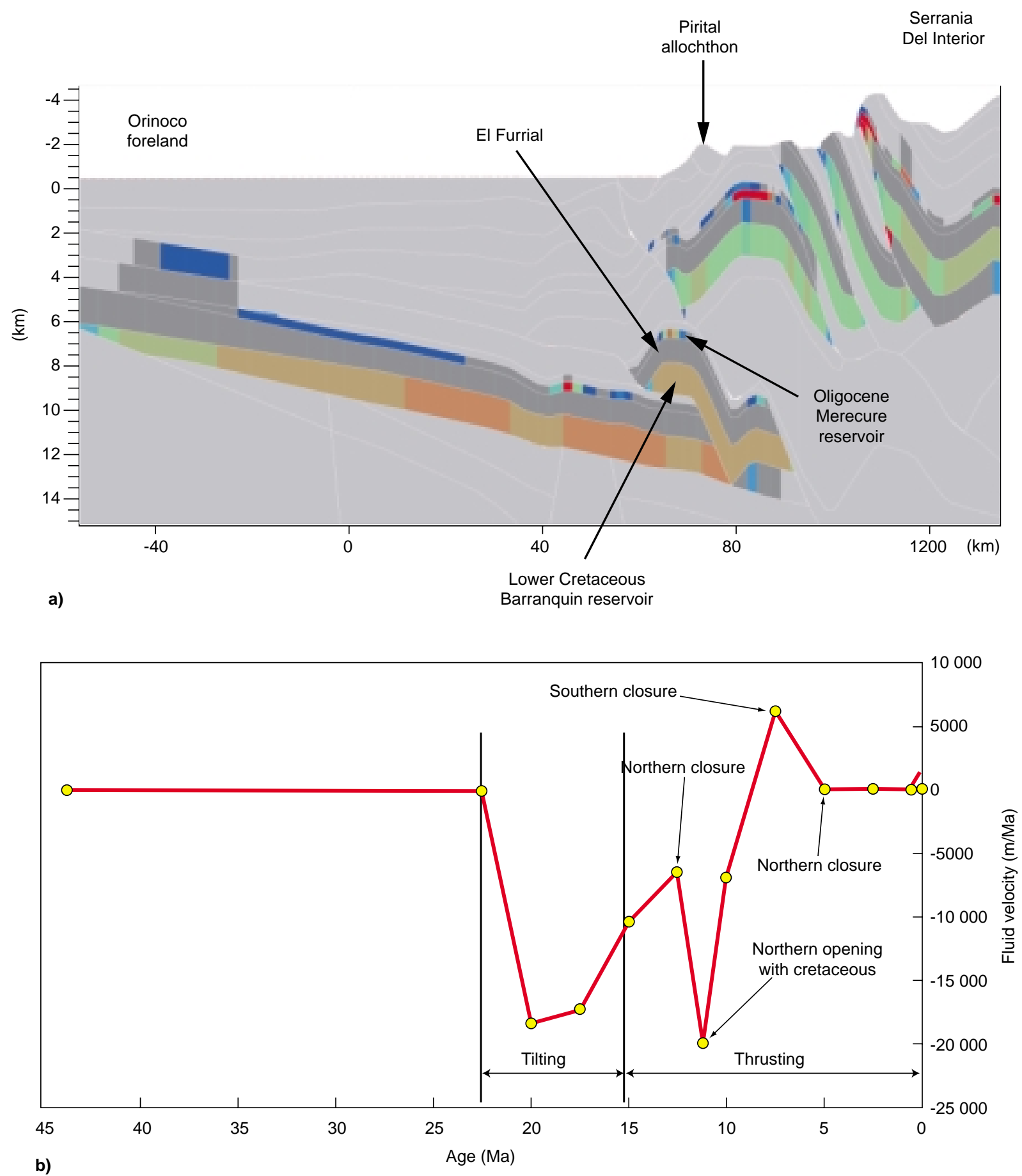

Figure 6

CERES fluid flow simulations along the Eastern Venezuela SUBTRAP transect. See Figure 1a for location. a) Present-day distribution of HC accumulations. CERES petroleum maturation and migration modeling accounts for the southward escape of HC toward the Orinoco foreland, trapping in the El Furrial field, but also for HC occurrences in the Prital allochthon as well as in shalloow prospects of the Serrania del Interior. Seemingly, results of CERES simulation outline the possibility for trapping HC in the lower Cretaceous Barranquin sandstone formation beneath the Querecual source rock horizons of the El Furrial trend. b) Fluid flow velocity versus time diagram in the Oligocene Merecure reservoir of the El Furrial field. Velocity values above zero indicate a transient circulation episode toward the north, at a time the El Furrial structural closure was already achieved in the south, but when the reservoir was still connected lateraly with the Pirital fluid conduits. Notice the main changes observed in the velocity of the fluids circulating toward the south, with a first squeegee episode followed by a recharge of the reservoir from the lower Cretaceous Barranquin aquifer of the Pirital allochthon (for further detail, see Schneider, 2003; Schneider et al., 2004). 
Such episode of syncompressional pore fluid pressure buildup can account for the development of hydraulic fracturing observed in the Neogene Carapita seal in the Eastern Venezuelan section. After structural closure, the hydraulic system can become completely closed in reservoir units of the frontal anticline and adjacent foothills. The fossilized overpressure regime is still preserved in the $\mathrm{El}$ Furrial trend in Eastern Venezuela (Fig. 6).

Alternatively, regional fluid flow can evolve again toward an open system after the end of thrust emplacement, being then controlled by the topography, as observed in the Canadian Rockies and adjacent foreland (Fig. 5).

\subsection{Changes in Lateral Velocity of the Fluid Flow as a Response to Squeegee Pulse and Thrust Closure}

Although CERES computations are only performed in 2D, we consider the resultant fluid flow velocity values are significant, assuming here that the overall structural grain in the Rockies and Eastern Venezuela is grossly cylindrical.

During the so-called squeegee episodes, fluids are expelled laterally from the footwall autochthon (subthrust units) toward the foreland with velocities ranging from a few kilometer per Ma in the Canadian foreland to up to $10 \mathrm{~km} / \mathrm{Ma}$ in Eastern Venezuela (Figs. 5 and 6; Schneider, 2003).

In Eastern Venezuela, deeper sedimentary units, namely the lower cretaceous Barranquin Formation of the Pirital allochthon came locally in contact with shallower units, e.g., Oligocene and late Cretaceous reservoirs of the adjacent foreland (the latter being currently tectonically accreted in the El-Furrial unit), giving rise to a second squeegee episode with velocities up to $20 \mathrm{~km} / \mathrm{Ma}$.

In contrast, the intensity of the lateral fluid flow remains low before and after the squeegee episodes.

\section{LPS CONTROLS ON RESERVOIR CEMENTATION}

Compaction and interaction between adjacent quartz or carbonate minerals can considerably modify reservoir properties.

Fine-grained pelagic limestone layers constitute the best lithofacies to study syn-compressional deformation structures such as Layer Parallel Shortening and coeval stylolitic joints, as the deformation is usually localized along regularly spaced surfaces oriented perpendicular to bedding. However, sandstone and dolostone reservoirs can also be affected during compression by more penetrative deformation, i.e. more diffuse pressure-solution and recrystallisation at grain scale, causing drastic changes in their total reservoir characteristics (Renard et al., 1997). Anisotropy of the magnetic fabric (AMS) proves to be a very efficient tool in both sandstone and dolostone for tracing the records of LPS deformation on core plugs collected from both wells and outcrops. The same samples can be subsequently prepared as thin-sections oriented parallel to the greatest principal stress $(\sigma 1)$, thus allowing visualization and quantification of the amount of tectonic compaction.

\subsection{Multiphase Quartz Cementation in Sandstone Reservoirs of Sub-Andean Basins in Colombia and Eastern Venezuela}

Roure et al. (2003) studied the influence of tectonic processes on total sandstone reservoir quality in Eastern Venezuela and Colombia. In the Llanos and eastern foothills of the Eastern Cordillera in Colombia, e.g., in the Cusiana field, the main reservoir is an Eocene fluvial quartz-arenite (Mirador Formation; Cazier et al., 1995; Graham et al., 1997; Warren et al., 1998; Warren and Pulham, 2001; Roure et al., 2003; Toro et al., 2004). In the Monagas fold belt in Eastern Venezuela, e.g., in the El Furrial field (Carnevali, 1988; Roure and Sassi, 1995; Gallango and Parnaud, 1995), the main reservoir is a quartz-arenite (Oligocene Merecure Formation), lacking both feldspar and lithic clasts.

\subsubsection{Origin of Silica}

Oriented thin-sections in these quartz-arenites show pressuresolution structures at the suture between adjacent detrital grains. The spatial distribution of pressure relative to the bedding and to the main horizontal stress $\sigma 1$ solution can also be described (Fig. 7). Most silica derived from pressuresolution is likely to have been redeposited immediately in adjacent pores of the reservoir, generating quartzovergrowths that progressively decrease both reservoir porosity and permeability.

However, recent studies of the aluminium content of the quartz-overgrowths within single sandstone layers of the Oligocene Merecure sandstone away from the shaley interbeds, show a significant decrease of $\mathrm{Al}$ from the outer part toward the central part of sandstone layers, thus pointing toward a possible secondary source of silica derived from the diagenesis of shaley strata (Pagel et al., in press).

\subsubsection{AMS and Fluid Inclusion studies: Dating the Main Cementation Episodes}

AMS studies were first interpreted to record layer parallel shortening (LPS) in the Oligocene Merecure reservoir at the El Furrial Carrito anticline in Eastern Venezuela (Aubourg, 1999). In most wells of the foothills in Colombia, LPS has been also observed in the Eocene Mirador reservoir, i.e., in the Coporo well, and in the Cusiana, Chichimene and Apiay fields, but not at Tame (Robion et al., 1997).

Fluid inclusion studies and thermal modeling also helped to date the main quartz-cementation episodes, which occurred mostly at the time of maximum burial (i.e. $4 \mathrm{~km}$ or 
Vertical plane

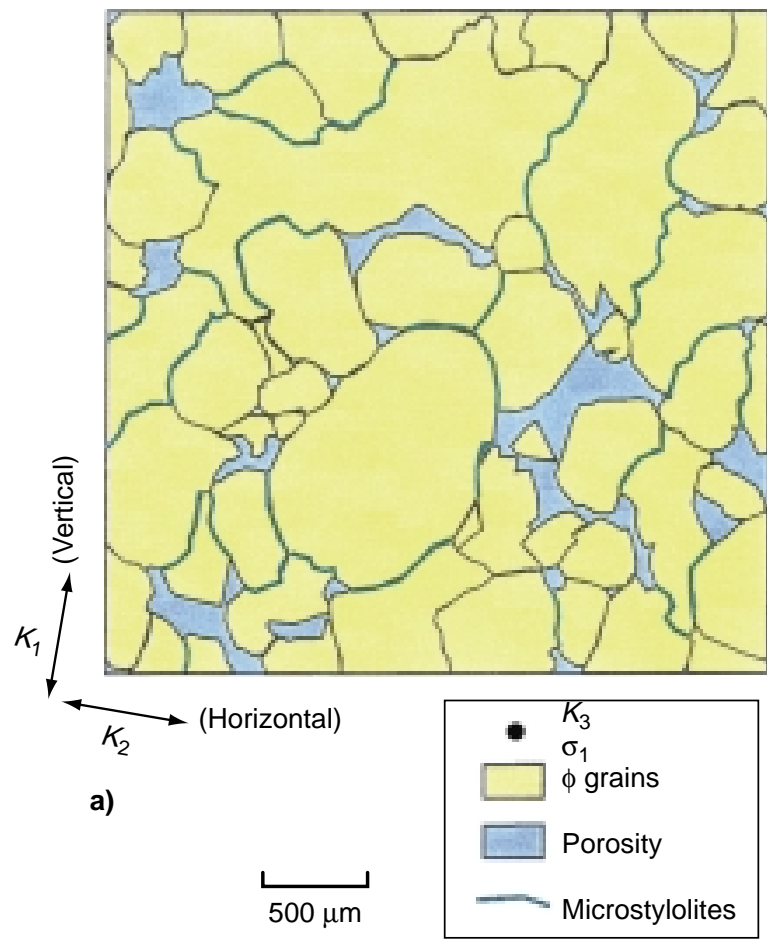

\section{Horizontal plane}

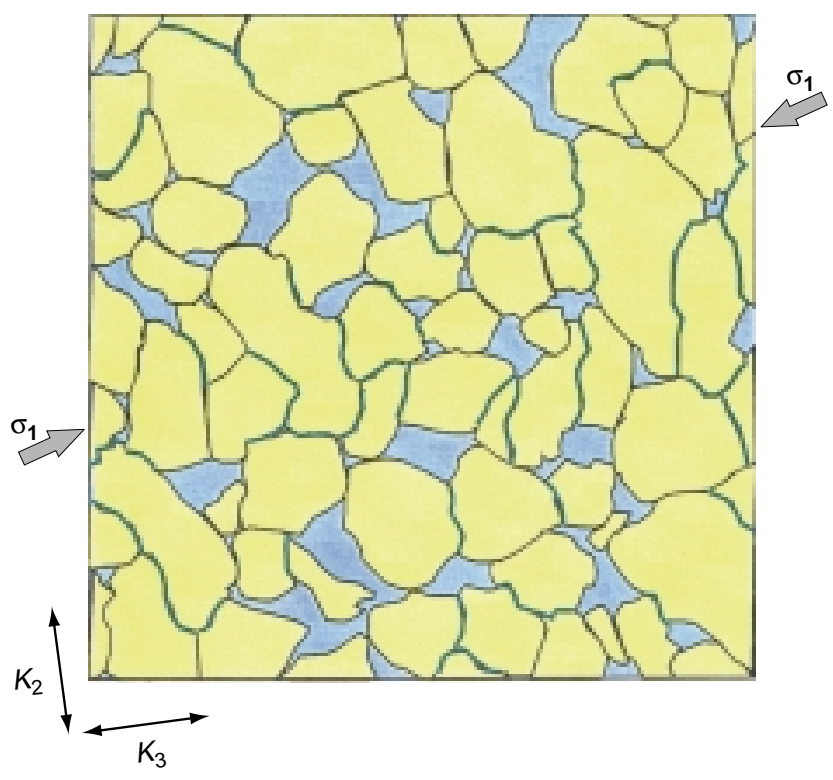

b)

Figure 7

Oriented thin-sections in the Oligocene sandstone reservoir of El Furrial, outlining the 3D distribution of deformation structures (pressuresolution, microcracks) with respect to the main principal stress direction ( $\sigma 1$, grossly parallel to $K_{3}$ axis as defined by AMS measurements): a) Vertical section orthogonal to $S_{0}$ and to $K_{3}$ axis. b) Horizontal section parallel to $S_{0}$ plane, and orthogonal to $K_{1}$ axis.

more) in the foredeep, when temperatures were between 110 and $130^{\circ} \mathrm{C}$ (Bordas-Lefloch, 1999).

These sandstone reservoirs from the Sub-Andean basins were compacted both vertically, by the load of the foreland sequence, and horizontally by tectonic stress (LPS) prior to being tectonically accreted to the allochthon. Layer-parallel shortening by pressure solution is the major source of silica in the underthrust foreland. Quartz cementation develops during a relatively limited time interval that is infered to be no more than a few million years, when the reservoir is damaged by the dual effects of LPS and deep burial (Fig. 8).

These Venezuelan and Colombian sandstones still have reasonably good reservoir characteristics, although they were buried to great depths. Overpressure that developed in these reservoirs as a result of rapid foredeep sedimentation probably delayed compaction. Early carbonate cements may have also contributed locally to prevent compaction until secondary porosity developed as a result of the dissolution of this early diagenetic phase. Finally, development of structural closures and hydrocarbon trapping has resulted progressively in the modification of the hydraulic system, and the progressive restoration of an overpressured regime, thus suppressing any local or exotic source of silica.
Most reservoirs display a dominant, single episode of quartz-cementation characterized by a single homogeneization temperature $\left(T_{h}\right)$ maximum that can be correlated with the onset of deformation (i.e., $110-130^{\circ} \mathrm{C}$ in Cusiana and El Furrial, representative of the late Andean-Neogene burial and deformation), the Mirador reservoir in the Medina field still records an earlier episode of cementation, at lower temperatures close to $80^{\circ} \mathrm{C}$, which is likely related to EoAndean-Paleogene burial and deformation (Fig. 9; BordasLefloch, 1999; Roure et al., 2003).

\subsubsection{Stable Isotopes Data and Origin of the Circulating Fluids}

No formation water has ever been collected in the El Furrial Oligocene sandstone reservoirs, due to the very large oil column and great depth of the structure. This prevents direct access to the water-oil contact. Due to the small size of fluid inclusions in quartz overgrowth (typically less than $3 \mu \mathrm{m}$ ), it was not possible to characterize directly the salinity of paleofluids in El Furrial reservoir using fluid inclusion studies, as a result of poor control on the melting temperature of ice crystals (Bordas-Lefloch, 1999). Therefore, it remains conjectural whether quartz cementation in these Venezuelan 

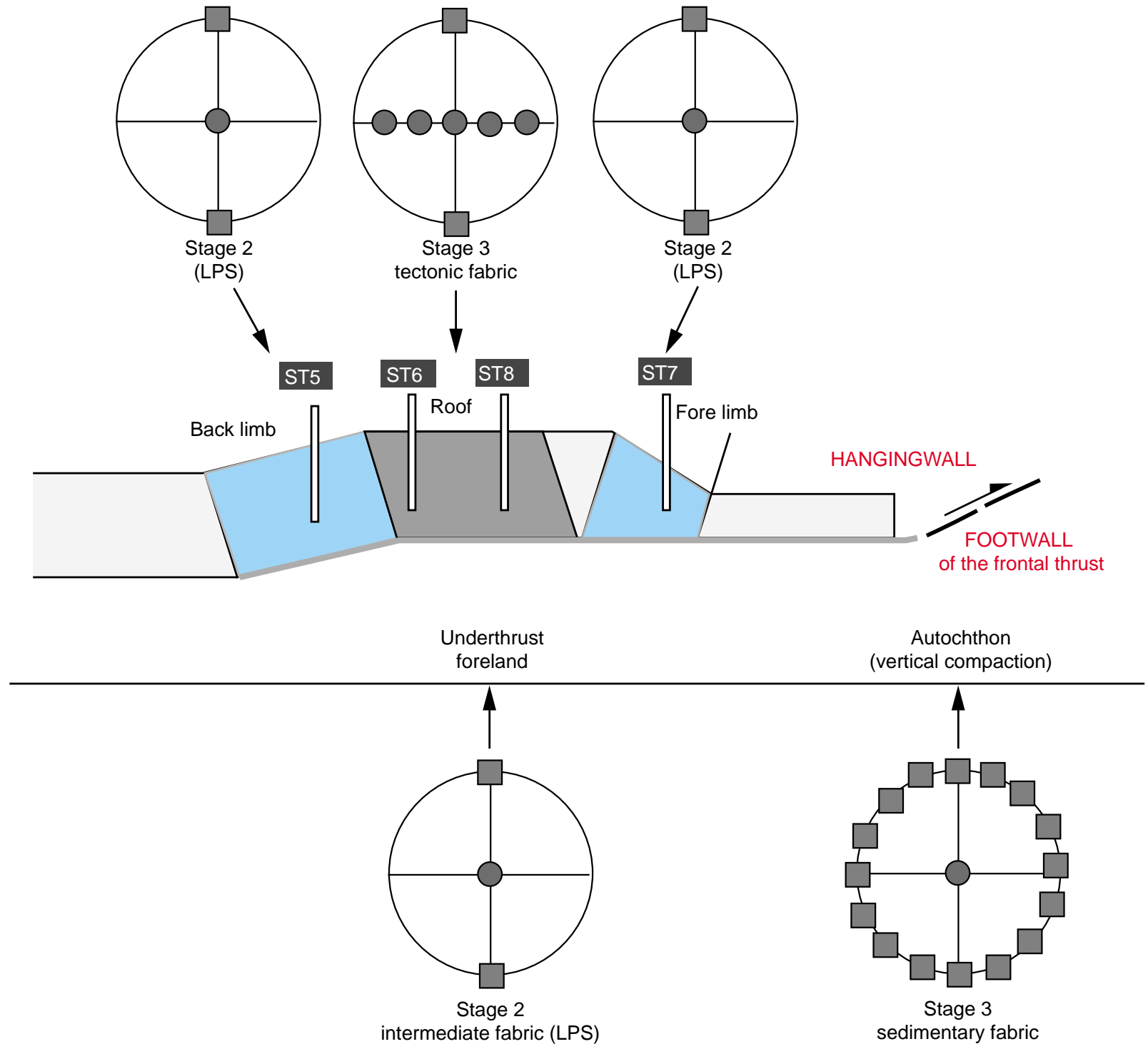

Figure 8

Total distribution of magnetic fabric anisotropy in the El Furrial anticline (Venezuela). Notice that all sites from the anticline record the LPS signature derived from their previous foreland evolution.

sandstone reservoirs occurred during episodes of lateral fluid migration involving dominantly basinal fluids, or if it occurred coeval with the topographically-induced flow of meteoric water.

Most quartz overgrowths identified in El Furrial sandstones belong to a single event, but minor secondary overgrowths can be observed locally. Fluid inclusions in the latter are characterized by the same $T_{h}$ distribution as the dominant quartz cement. These two generations of quartz cements were also sampled for $\delta^{18} \mathrm{O}$ isotope studies using laser-probe investigations (Pagel et al., in press). This study showed that the main quartz cementation episode involved a formation fluid that was equilibrated with the host Oligocene sandstone, with a signature typical of the basin. $\delta^{18} \mathrm{O}$ values in the second generation of quartz overgrowths were significantly shifted from these host-rock buffered values, indicating a distinct origin of coeval circulating fluids, assuming both quartz cementation episodes occurred at similar burial-temperatures. CERES software fluid flow has subsequently simulated the possibility of recharging the El Furrial Oligocene reservoirs with formation waters from the lower Cretaceous Barranquin aquifer that occurs in the Pirital hanging-wall unit (Fig. 10; Schneider, 2003; Schneider et al., 2004). Therefore, it is assumed that the quartz cementation events in El Furrial occurred during at least two distinct episodes, the first when only lateral 
1) EL FURRIAL PROSPECT (Merecure reservoir) Eastern Venezuela

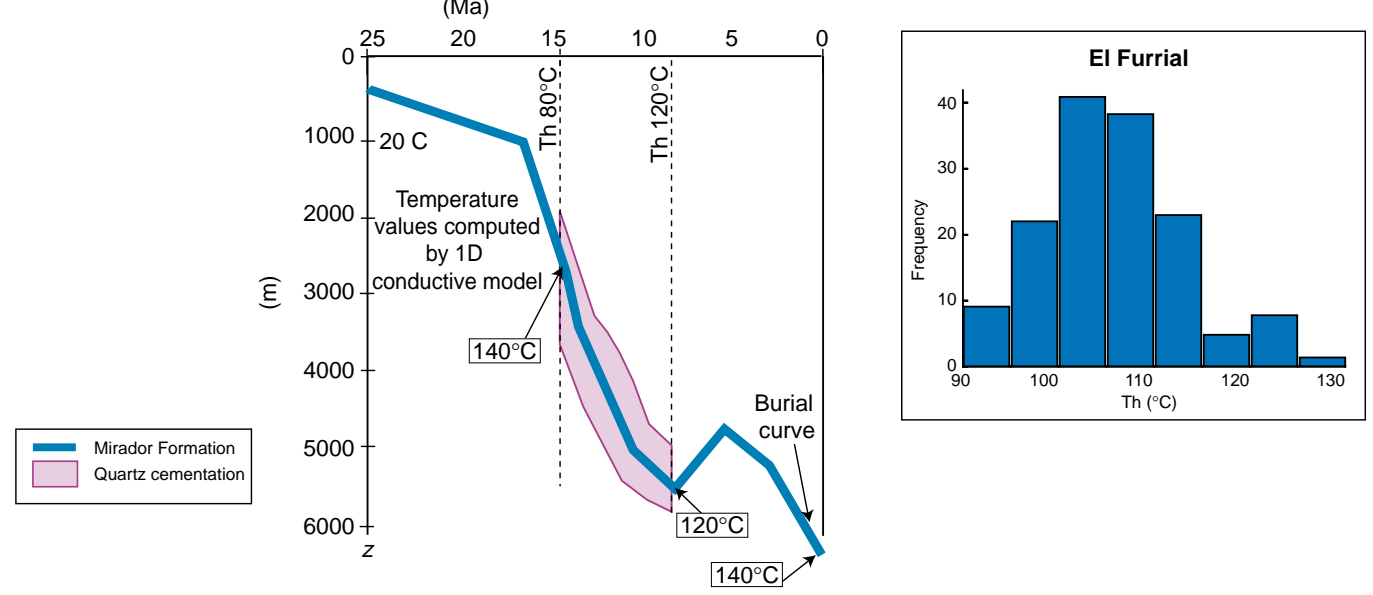

2) CUSIANA PROSPECT (Mirador reservoir) Llanos foothills
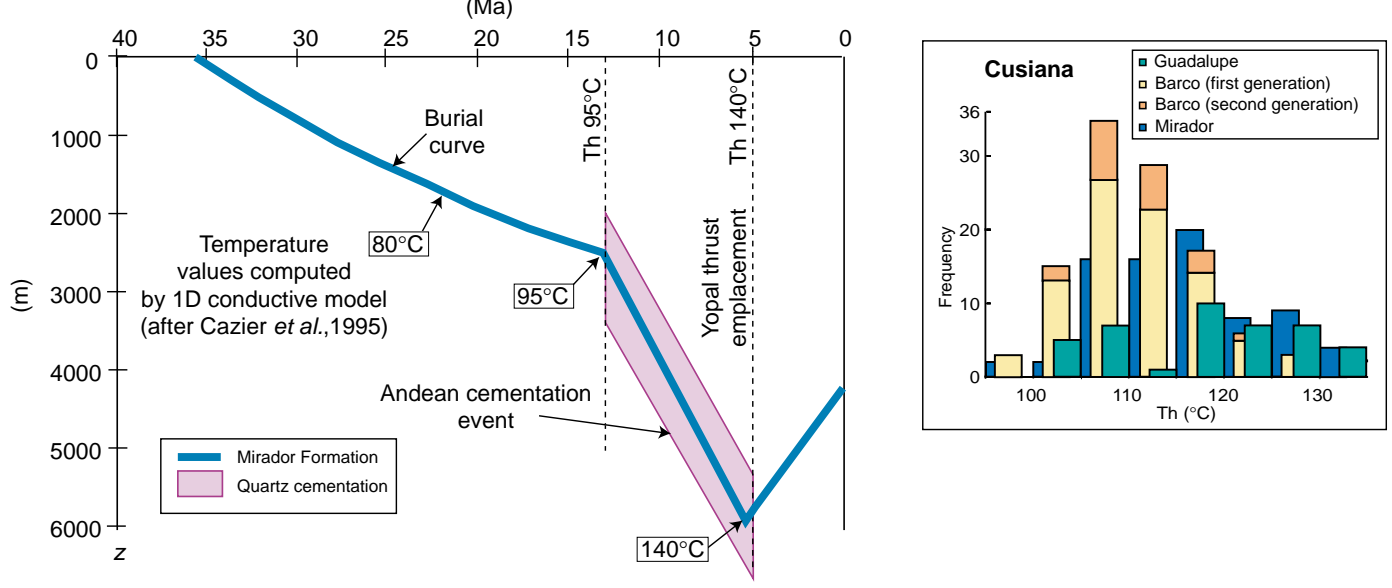

3) MEDINA PROSPECT (Mirador reservoir) Llanos foothills

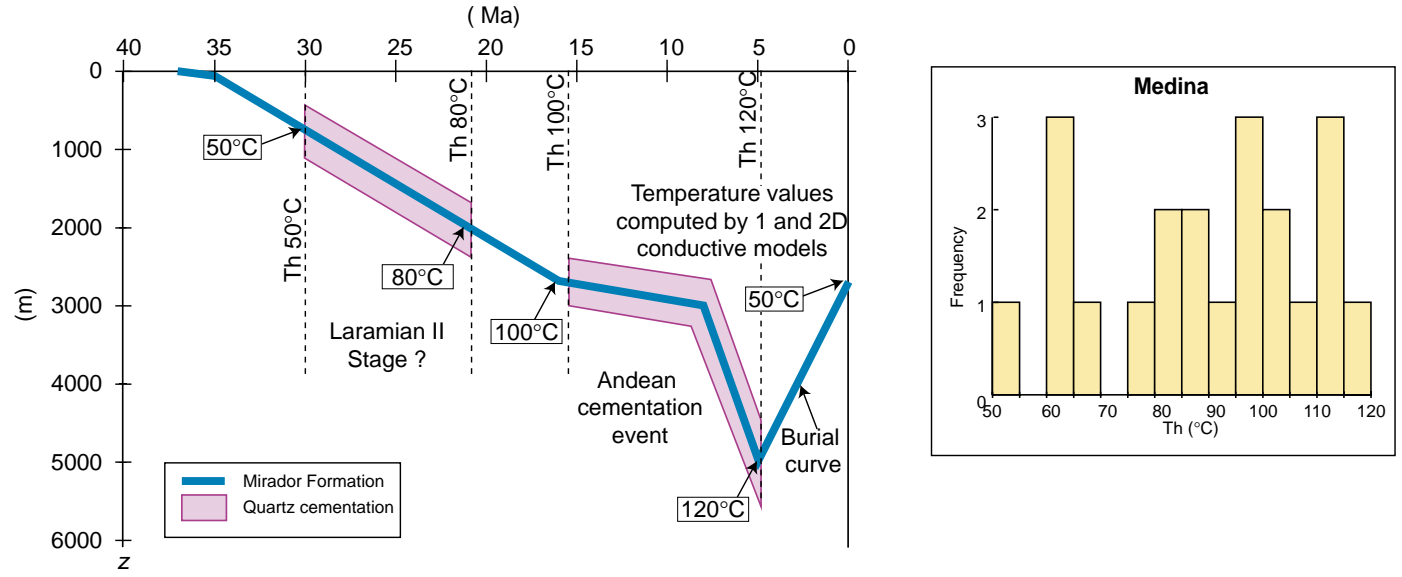

Figure 9

Burial-temperature curves of Sub-Andean prospects and coeval dating of quartz-overgrowth (after Bordas-LeFloch, 1999, see location of the wells and field in Figure 1a and 1b). El Furrial (Venezuela) and Cusiana (Colombia) record a single quartz-cementation episode, coeval with the Andean deformation and development of LPS. However, the Medina well (Colombia) also displays an earlier, lower temperature cementation episode, likely related to Paleogene Laramian deformation, at a time when the Mirador reservoir was less deeply buried, but already affected by tectonic stress. 
$12 \mathrm{Ma}$ (the Barranquin aquifer of the Pirital allochthon expells fluids laterally into El Furrial reservoirs)
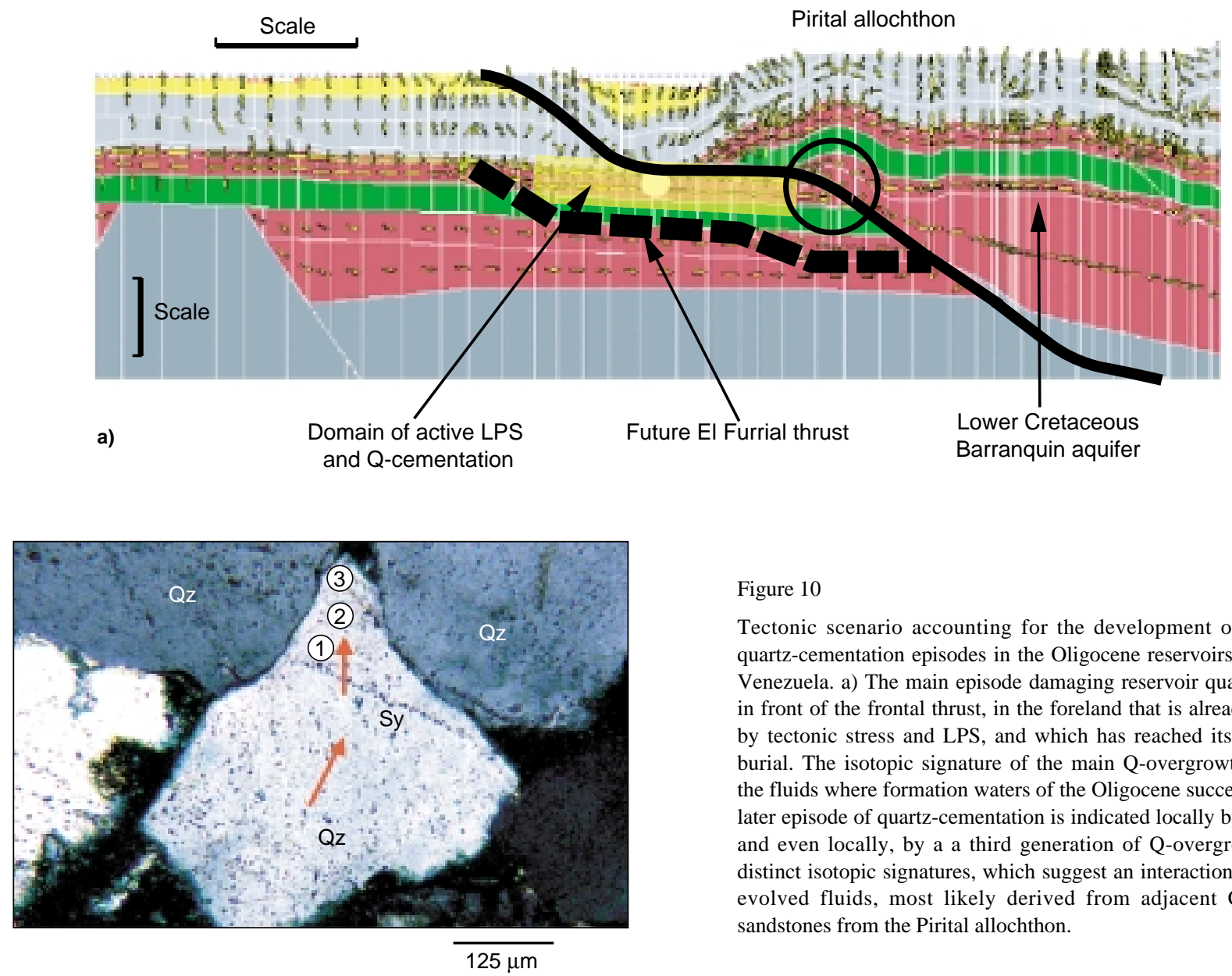

Figure 10

Tectonic scenario accounting for the development of LPS and quartz-cementation episodes in the Oligocene reservoirs in Eastern Venezuela. a) The main episode damaging reservoir quality occurs in front of the frontal thrust, in the foreland that is already affected by tectonic stress and LPS, and which has reached its maximum burial. The isotopic signature of the main Q-overgrowth suggests the fluids where formation waters of the Oligocene succession. b) A later episode of quartz-cementation is indicated locally by a second, and even locally, by a a third generation of Q-overgrowth, with distinct isotopic signatures, which suggest an interaction with more evolved fluids, most likely derived from adjacent Cretaceous sandstones from the Pirital allochthon.

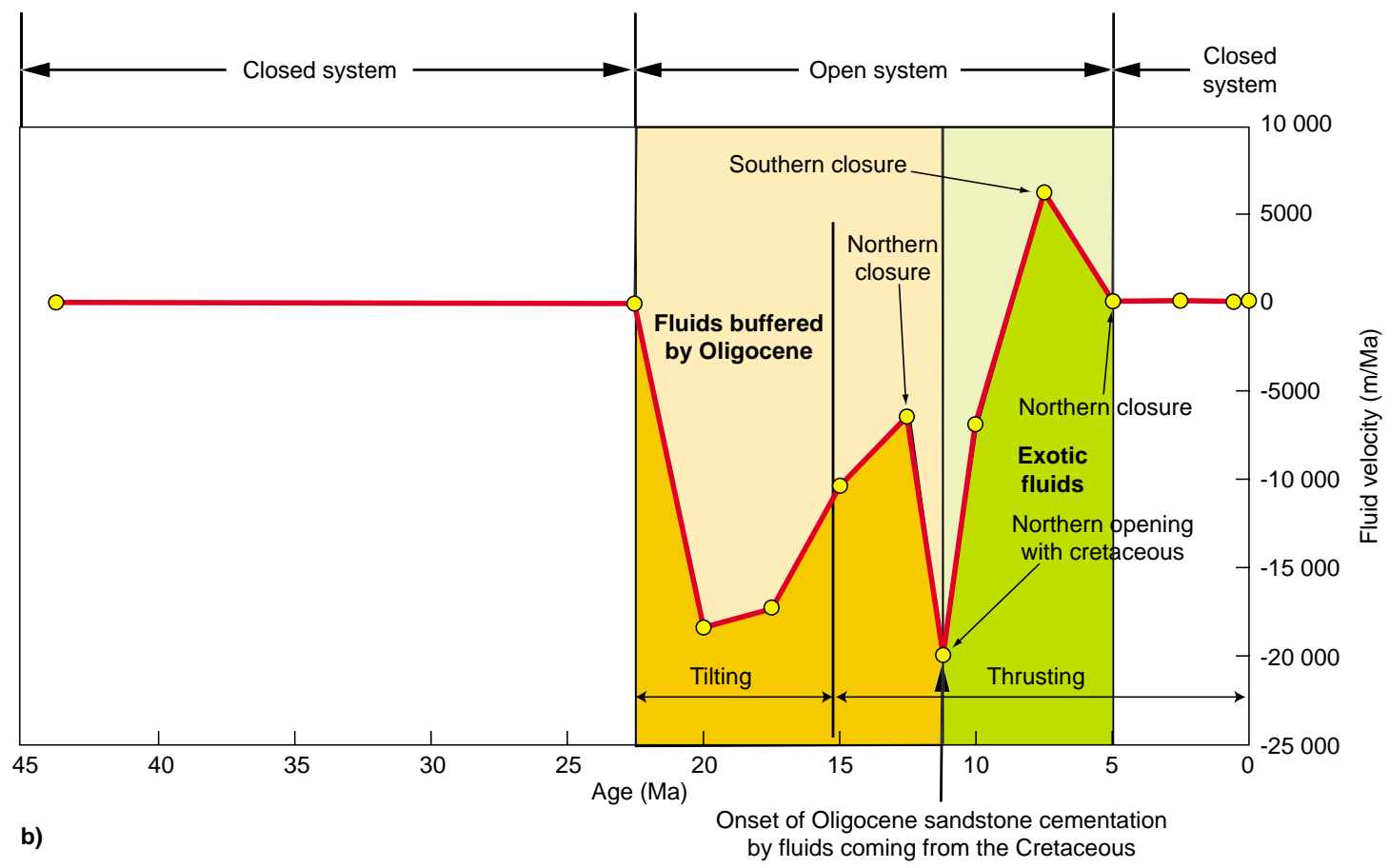


intraformational fluid migration occurred, and the second when tectonic uplift of the Pirital allochthon allowed recharge of the Oligocene formations in the footwall by older aquifers in the allochthon.

\subsection{Mesodolomite and Syn-LPS Recrystallisation of Dolostone Reservoirs in the Foreland Belt and Basin of the Canadian Cordillera}

In major parts of the Foreland Belt and Basin of the Canadian Cordillera, some of the best reservoir strata occur in dolomitized Devonian and Mississippian strata. However, reservoir characteristics are highly variable in the dolostones, and depend on crystal fabric relative to initial dolomitisation processes and/or recrystallisation and secondary porosity development:

- Pervasive fine to medium crystalline dolostones can be inferred to have an eogenetic origin, being controlled by paleo-environments, and therefore, they are not relevant to FFTB processes and evolution.

- Two other types of dolostones resulting from late burial evolution occur in Cordilleran Foreland Belt, i.e. the mesodolomites and zebra dolomites, which are both discussed below.

Numerous wells penetrating the autochthonous foreland have been sampled, as well as surface outcrops in the foothills, allowing a comparison to be made between Paleozoic carbonate reservoirs in portions of the foreland that are located at various distances from the thrust front, in reservoir strata that are now tectonically accreted into the allochthon.

\subsubsection{Petrographic, Isotopic and Magnetic Characteristics of Mesodolomites}

Mesodolomite is a general term that describes medium to coarse $(50-1000 \mu \mathrm{m})$ crystalline dolomitic lithologies. These dolomites are clearly less porous than the others, with the exception of lithologies where a secondary macroporosity exists. Typically, an increase in non-planar crystal boundaries occurs with increasing crystal size (Fig. 11). Based on their extinction pattern under crossed polarizers, the internal structure of the mesodolomite crystals is composed of different sectors, explaining the mosaic extinction pattern. Locally some smaller sucrosic dolomite crystals float within the mesodolomite crystals. These fabrics point towards a recrystallisation origin of the mesodolomites, as advocated by many authors.

However, fabric replacive mesodolomites, as indicated by the preservation of relict structures from the original strata (e.g. oolites, bioclasts, etc.) also exist. In most of these dolomites, carbon isotope ratios appear to be buffered by the precursor carbonates (Cioppa et al., 1999; Al-Aasm and Packard, 2000). $\delta^{18} \mathrm{O}$-values are always rather depleted and

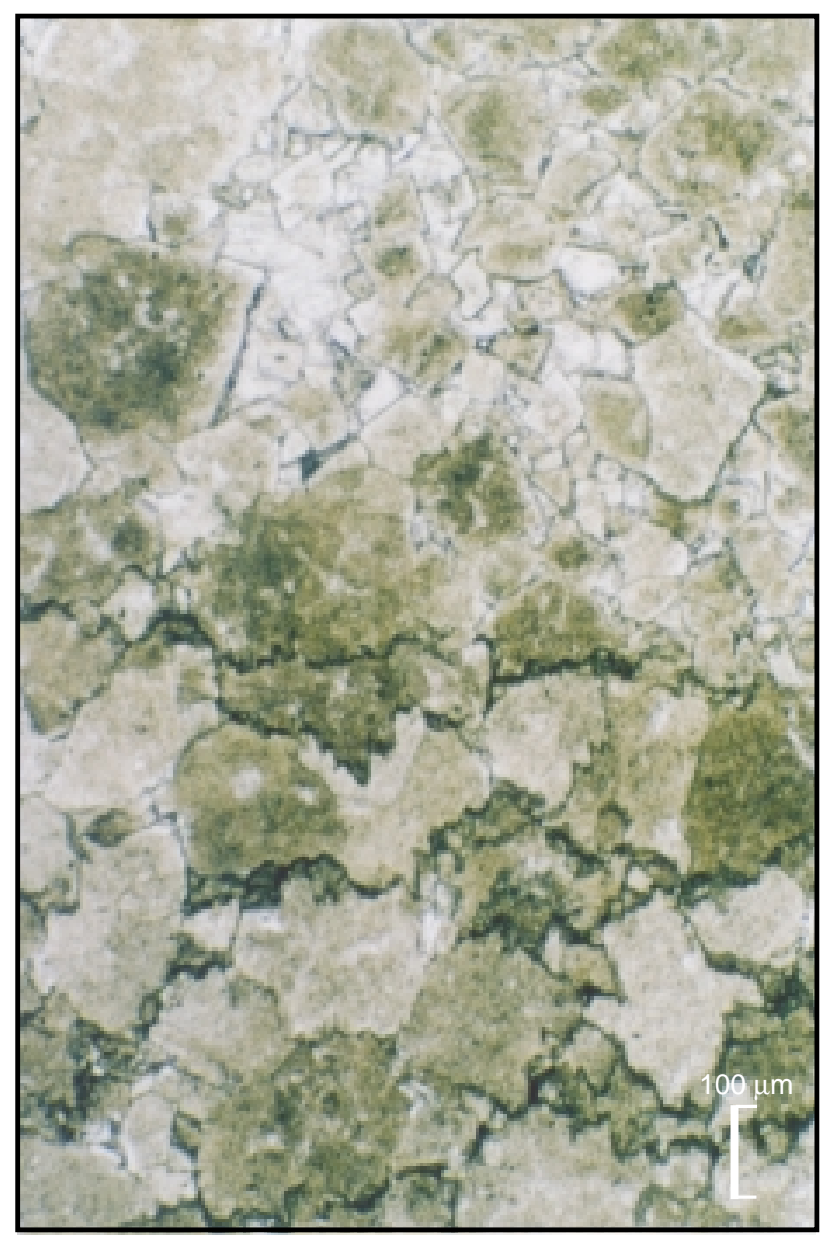

Figure 11

Thin-section illustrating the strong recrystallisation of mesodolomite from the Alberta foreland, in an area where AMS data clearly document the imprint of LPS.

often plot below $-8 \%$ versus PDB. Often the coarsest fabrics possess the most depleted oxygen isotopic signatures. The isotopic variations of the mesodolomite often show a correlated trend between oxygen and carbon isotopes (AlAasm and Lu, 1996; Al-Aasm et al., 1996; Cioppa and Symons, 2000). Mesodolomites show higher ${ }^{87} \mathrm{Sr} /{ }^{86} \mathrm{Sr}$ isotope ratios than coeval seawater.

Cioppa et al. (1999) identified a correlation of magnetic grain size and isotope signature in the mesodolomites. Chemical remagnetization has overprinted the primary Paleozoic magnetisation of the reservoirs as far as $150 \mathrm{~km}$ away from the Front Ranges, with polarities reverse in the foothills, and both reverse and normal in Interior Plains, showing a diachronous acquisition of the magnetization in carbonate rocks (Enkin et al., 2000; Cioppa et al., 2001, 2003, 2004; Robion et al., 2002, 2004). This dolomite possesses a late Cretaceous to Paleocene paleomagnetic remanence, pointing towards a dolomitisation and/or recrystallisation 
event during Laramide deformation (Symons et al., 1998, 1999; Enkin et al., 2000; Robion et al., 2004).

Many Paleozoic samples from the foreland autochthon, as far as $150 \mathrm{~km}$ east of the thrust front, record a typical LPS signature on AMS measurements, whereas in the inner foothills and Front Range samples locally record an additional, post-tilting overprint which accounts for continued tectonic compaction during progressive tectonic stacking within the allochthon. "Stylolitic cleavage" magnetic fabrics dominate in Front Ranges. In the foothills, the magnetic foliation is interpreted as parallel to tension gashes. The magnetic lineation is inferred to indicate the shortening direction. Similar tension gashes fabrics are observed in the Interior Plains. Assuming tension gashes fabric is an extreme case of the recrystallization fabric, the eastward evolution of the magnetic fabrics accompanied by lost of sedimentary signature indicates that the chemical remagnetization overprint is more active in front of the foldand-thrust belt. Furthermore, chemical remagnetization and magnetic fabric records in Paleozoic reservoirs in Plains are not as pervasive as in the allochthon, and it may be controlled by a low concentration in iron oxides or weak magnetic anisotropy. More than $60 \%$ of samples were rejected from the magnetic study because they had no remanence signal nor any magnetic fabric. Furthermore, we did not find any direct relationship between the lack of magnetic signal and mesodolomite occurrence.

\subsubsection{Origin of the Mesodolomite}

The present study suggests strongly that the tectonic fabric coeval with the early LPS deformation history is the driving mechanism for the chemical overprint of the primary magnetization, as well as the recrystallisation of Paleozoic carbonate reservoirs.

Whether the mesodolomite should be explained by wholesale replacement of a pre-existing dolomite (e.g. eogenetic dolomite) or whether it corresponds to a replacement of a previously non-dolomitised limestone is matter of debate. Some replacement, i.e. samples possessing relict textures of the precursor limestones, clearly occurs, but based on the study of more than 100 thin-sections, $<10 \%$ are of this type. However, a major Mg mass-balance problem occurs if the other $>90 \%$ have to be explained in a similar way. Therefore, a dominant replacement origin of a preexisting dolomite is favoured (see also Al-Aasm and Packard, 2000). This interpretation also concurs with the conclusions drawn from several modeling studies (e.g., Deming et al., 1990; Ge and Garven, 1992, 1994), that only relatively small volumes of fluids from an external source are inferred to flow through a limited rock volume, compared to the existing connate water in the rock volume. This is also advocated by many authors studying cement types and dolomitisation in FFTB systems (Muchez et al., 1994; Machel and Cavell, 1999).

Therefore, we favour a model where mesodolomite is primarily a recrystallisation product of fine crystalline dolomite and where LPS is the driving force causing the large scale recrystallisation.

According to Averbuch et al. (1992), LPS stylolitic planes develop immediately prior to thrust emplacement. Since mesodolomites record a LPS related magnetic fabric, we advocate that the recrystallisation of matrix dolomite and mesodolomite formation occurred just before thrust emplacement when tectonic compression was highest. We thus propose a caterpillar-like displacement of the recrystallisation front during thrust emplacement. This scenario was already invoked by Enkin et al. (2000) to explain migration of remagnetization front and subsequent diachronic recording of chemical remagnetization in the foreland.

In this scenario, there will be a progressive resetting of the stable oxygen isotope composition and recrystallisation temperatures that is recorded in the newly formed fluid inclusions. These values will, however, differ from place to place as a function of position in the tectonic wedge. Carbon isotope values will be rock buffered, as long as no additional carbon source is available. The fact that the latter has not been dramatically reset also indicates that recrystallisation predates hydrocarbon expulsion.

The slight increase in ${ }^{87} \mathrm{Sr} /{ }^{86} \mathrm{Sr}$ isotopic ratio composition is often explained by involvement of radiogenic $\mathrm{Sr}$ derived from intrabasinal shales. However, it should be investigated whether intrastratal clay components in the dolomites are not another possible candidate for the source of radiogenic Sr. This intrastratal source would also explain both the authigenic quartz that is locally observed in the mesodolomites and the slight higher Fe contents.

It is well-known that dolomite has a high recrystallisation potential and that normally recrystallised dolomites are more stoichiometric than non-recrystallised dolomites (Gregg and Shelton, 1990; Smith and Dorobek, 1993; Nielsen et al., 1994). This seems, however, not to be the case in the mesodolomites studied in Canada. This is explained in the model by recrystallisation in a tectonic strain field with low water circulation.

\section{LATE CARBONATE DISSOLUTION AND DOLOMITIZATION IN AN OPEN SYSTEM}

Although tectonic compaction can operate at the scale of individual minerals or layers, even in a dominantly closed system, most other diagenetic transformations are likely to involve larger chemical transfers, due to the lateral or vertical advection of exotic fluids in the reservoir. 
Hydrothermal brines, i.e., saline fluids with a temperature higher than the host rock, are common features where there is active flow of compaction water, for instance when the fluids can be channelized in high porosity/permeability strata near potential vertical conduits such as mud diapirs, normal faults and thrusts. They have been observed and interpreted in modern accretionary wedges where they account for active hydrothermal springs in the vicinity of major thrust faults (Henry et al., 1989). Paleo-migrations of hot waters are also recorded by the trapping temperature of coeval cements in the vicinity of inverted basins and reactivated high-angle basement-involved faults, i.e. in the Sabana de Bogota in Colombia, in the Alpine foreland in France (Guilhaumou et al., 1996; Léost et al., 1995, 1998; Léost, 1998), and along the basal décollement of fossil accretionary wedges, i.e., in Sicily (Larroque, 1993; Guilhaumou et al., 1994; Larroque et al., 1996), or in major overthrust settings (Lünenschloss et al., 1997).

\subsection{Hydrothermal Karsts and Mississippi Valley Type ore Deposits}

In addition to normal fault and thrust systems, flow can occur in carbonate layers, interbeded stylolitic planes, unconformities and paleo-karst surfaces. All these can act as conduits for the channelized flow of hydrothermal brines, especially when they are overlain by efficient seals, thus resulting in the development of secondary porosity by dissolution, and forming so-called hydrothermal karst systems, e.g. in the foothills of Tunisia and Pakistan (Benchilla, 1999), and in the Variscan fold-and-thrust belt (Dejonghe et al., 1998; Nielsen et al., in press). They can also result in the deposition of new cements, especially updip of the regional foreland flexure.

When saline fluids also interact with siliciclastic formations, subsequent fluid migration may contribute to the development of Mississippi Valley Type (MVT) ore deposits within more distal and shallower carbonates. MVTs are known to host fluorite, barite, galena, sphalerite, pyrite, dolomite, quartz, and of course any type of Fe-calcite (Leach and Rowan, 1986; Packard et al., 1990; Nakal et al., 1993; Muchez et al., 1994; Qing and Mountjoy, 1995). These ore deposits occur in most FFTB around the world, i.e., in the foreland of the Appalachians, Ouachitas and Rocky Mountains in North America, in the Ardèche part of the Alpine foreland in France, the frontal areas of the Variscides in the United Kingdom, Belgium and Germany, and also in the foothills of Tunisia and Pakistan. Some of these deposits have been dated using isotope geochronology and paleomagnetism. The latter often appear time-equivalent with active dewatering processes in the adjacent foredeep, coeval with episodes of major tectonic contraction in nearby foothills and thrust belts (Fig. 2).

Hydrocarbon fluid inclusions hosted in these deposits, i.e., in the fluorite of Baluchistan in Pakistan and along the
North-South Axis in Tunisia, show that the coeval paleofluids had a basinal origin, and were derived from domains where the petroleum source rocks were already in the oil window, which is usually not the case for the maturity indicators found in the mineralized host rock (Benchilla, 1999; Guilhaumou et al., 2000).

\subsection{Synkinematic Fluid Escapes and Development of Zebra Dolomite}

Zebra dolomites are exposed in the vicinity of Lake Louise and west of the regional transect studied in the Canadian Cordillera, i.e., an area where the upper CretaceousPaleocene tectonic wedge is dominantly made up of Paleozoic schists and older formations, in the vicinity of the former paleo-passive margin platform to basin transition, which coincides in this area with the eastern boundary for post-orogenic Eocene extension.

\subsubsection{Petrographic, Isotopic and FI Data of the Zebra Dolomites}

Zebra dolomites are characterized by a repetition of 1-10 mm thick dark grey (a) and white (b) dolomite bands, building up abbabba-sequences. The (b)-bands can make up between 50 to $65 \%$ of the zebra pattern. A central cavity, up to several $\mathrm{mm}$ across and few $\mathrm{cm}$ long, may separate two adjacent (b)sheets, giving a total porosity of about $3 \%$, but the presentday porosity is extremely variable and it varies from 0 to $10 \%$. The zebra dolomite patterns seem to develop parallel to bedding $\left(S_{0}\right)$ as well as cleavage $\left(S_{1}\right)$ planes (Vandeginste $e t$ al., 2004; Fig. 10).

The transition to the host limestone can be very sharp and is locally bordered by subvertical fractures. This observation already leads to the conclusion that there is a tectonic control on the development of this dolomite type. This is also indicated by the fact that $\mathrm{mm}$ - to $\mathrm{cm}$-scale subvertical displacements of the zebra bands occur. The degree of displacement gradually evolves to a maximum before it fades back to zero over a distance of a few centimeter. Intracrystalline displacements within cement zones have been recognized (Swennen et al., 2003b). These features are similar to the features described by Nielsen et al. (1998) in the Variscan front zone in Belgium. Typical of these lithologies is the small scale development of stylolites within the dark grey bands or at the contact between the (a) and (b) bands.

The dark grey (a) zebra dolomite bands are composed of medium to coarse crystalline $(50-300 \mu \mathrm{m})$, inclusion-rich turbid non-planar xenotopic-A interlocking dolomite crystals. Between the crystals, detrital clay occurs as well as some authigenic Al-silicate phase. The contact between the dark grey (a) and white (b) zebra bands is gradational and characterized by an increase in crystal size toward the 
b-sheets. Dolomite crystals in the latter are coarse crystalline $(0.5-5 \mathrm{~mm})$ and non-planar to planar-C. Because of the presence of numerous inclusions, the (b)-crystals are generally milky white. Next to the cavities, transparent and almost inclusion-free crystal rims develop. The (b)-crystals display sweeping extinction and curved planes typical of saddle dolomite. Fluid inclusions in (a) as well as (b) zebra bands are generally $<3 \mu \mathrm{m}$ in size. Microthermometric measurements addressed by Vandeginste et al. (2004) indicate that the dolomites formed from relatively hot $\left(T_{h}=125\right.$ to $\left.195^{\circ} \mathrm{C}\right)$ saline (20-23 wt $\% \mathrm{CaCl}_{2}$ eq.) fluids. A late diagenetic high temperature origin is also supported by extremely depleted $\delta^{18} \mathrm{O}$ values ( -20 to $-14 \%$ o versus $\left.\mathrm{PDB}\right) . \delta^{13} \mathrm{C}$ plot between -2.8 and $-0.1 \%$ versus $\mathrm{PDB}$, and can be explained by hostrock buffering and temperature related depletion. No difference exists between the (a) and (b) bands. Both bands are more or less stoichiometric (50-52 $\left.\mathrm{mol} \% \mathrm{CaCO}_{3}\right)$.

\subsubsection{Origin of the Zebra Dolomites}

Zebra dolomites are usually related to the expulsion of suprahydrostatic fluids during a tectonic compressional phase
(Nielsen et al., 1998). Dolomitization in studied Canada outcrops could have been caused by hydrothermal brines that originated within the basinal areas of the orogenic wedge circulating deep within the crust, and ascended in the external zones, thus providing the lateral-vertical transfer of $\mathrm{Mg}$ required for dolomitisation of original limestone formations. In this respect, the location of Canadian zebra dolomites could be controlled by the former paleo-geographical transition from Cambrian platform to basinal facies. Notably, both ferroan and non-ferroan zebra dolomites occur adjacent to each other in the Canadian Cordillera and can be explained by differences in oxido-reduction potential. In this case a mechanism invoking $\mathrm{Fe}$-depletion due to $\mathrm{Fe}$-sulphide formation could explain the difference in $\mathrm{Fe}(-\mathrm{Mn})$ content between adjacent zebra dolomite regions (Vandeginste et al., 2004). Another possible explanation is given by localized fluid flow of different systems.

Cross-cutting relationships here demonstrate that zebra dolomitisation post-date the development of the $S_{1}$ cleavage (Fig. 12). The cleavage most likely developed parallel to the axial surface of late Cretaceous-Paleocene Laramide folds,

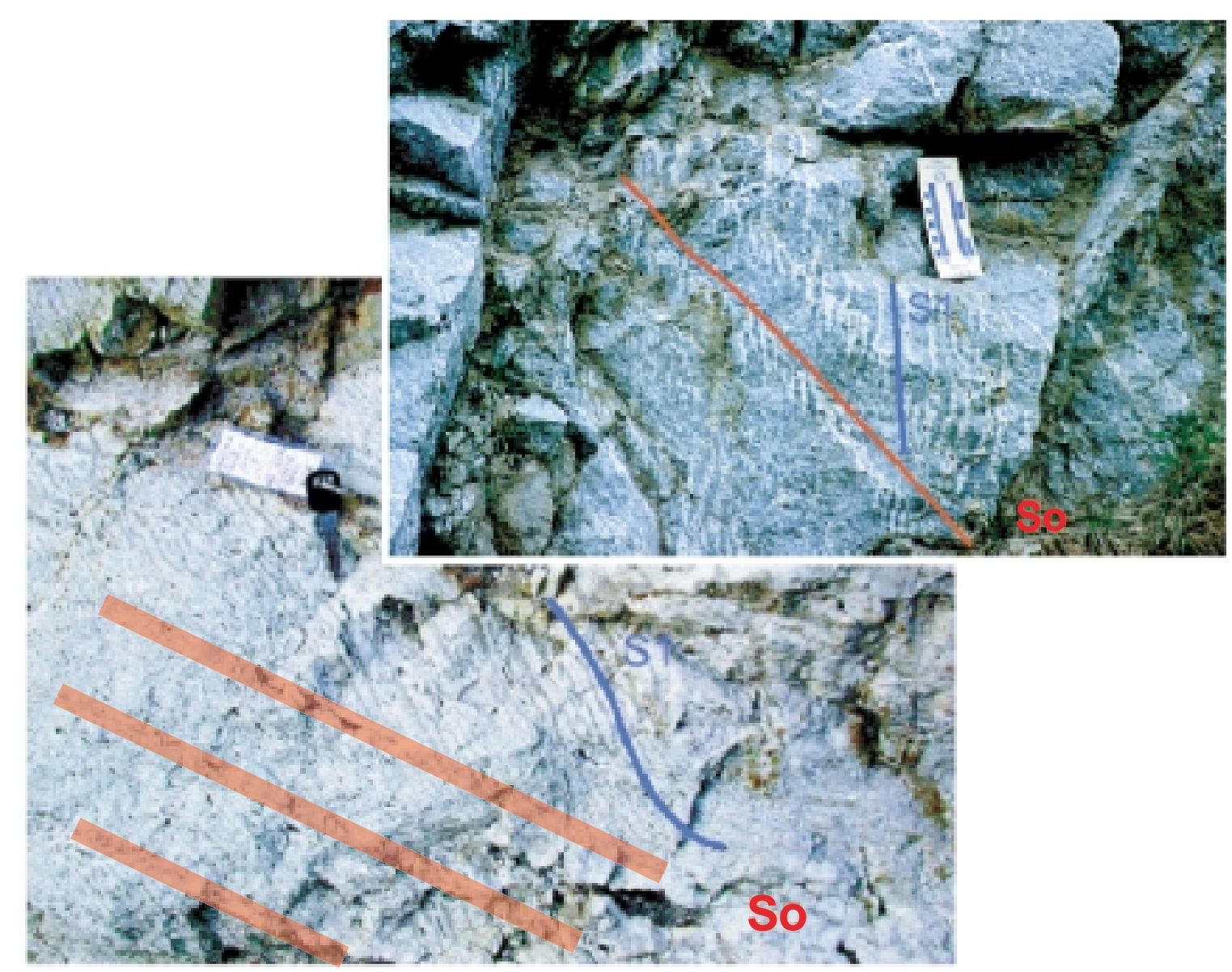

Figure 12

Outcrop picture of zebra dolomite from the Canadian Rockies documenting the relative timing between $S_{1}$ cleavage development and subsequent dolomitization. 
because there is no evidence of any Paleozoic folding nor post-Antler unconformity in this region. Thus, dolomitization post-dates the folding and syntectonic horizontal contraction of this tectonic unit. Therefore, the most challenging question remaining is, how to account for such a large amount of dolomitizing fluids circulating in the system after folding, axial plane cleavage development and sedimentary dewatering occurred?

At this stage, numerous scenarios can be proposed to account for this late dolomitization (Figs. 13a, b, $c$ and d).

\section{Syn-Compressional Hypotheses}

One solution is to infer that mineralizing fluids are coming from another, deeper but more external tectonic unit, located in the footwall of the dolomitized zone, thus implying a multiphase stacking-dewatering process, assuming a piggyback sequence of thrusting (Figs. 13a and b). Such a scenario, with fluids migrating from the footwall toward the hangingwall of a major thrust has been well documented by the study of the petroleum systems in the Wyoming overthrust belt, where productive Paleozoic reservoirs in the foothills are charged by crude oil generated in the Cretaceous source horizons of the foredeep (Deming and Chapman, 1989).

A second solution would be to recharge the dewatered Paleozoic formations using fluids coming from a more internal unit, but with a deeper, possibly Infracambrian aquifer, assuming out-of-sequence thrusting or reactivation of a former thrust (Fig. 13b). Such a scenario, with fluid migration from an inner unit toward a more external structure, has been documented already by Pagel et al. (in press) to account for a second generation of quartz overgrowth in the Oligocene El Furrial reservoir in the Eastern Venezuelan transect (see Section 3.1). In this context dewatering in relation to smectite to illite transformation could also account for the zebra dolomitization. According to Boles and Franks (1979), this transformation liberates a large amount of water, $\mathrm{Mg}$ and $\mathrm{Fe}$.

\section{Syn-Extensional, Post-Compressional Hypotheses}

An alternate solution would be to recharge the system by meteoric water during the unroofing of the allochthon, either when the outer foothills were still shortening, or more likely during post-orogenic extension (Fig. 13c). However, this conflicts with fluid inclusion data (salinity $=20-23 \mathrm{wt} \%$ $\mathrm{CaCl}_{2}$ eq.). In such a scenario, the opening of brittle fractures and cleavage planes would be enhanced by the Eocene extension, at a time of asthenospheric rise, plutonic intrusions and emplacement of metamorphic core complexes could account for an elevated thermal regime.

The results of a CERES model along this transect accounts for the local development of convection cells in the allochthon, with local charge of meteoric water in the anticlines, heating of the fluids in the underthrust synclines, and resurgence of hydrothermal springs along the thrust surfaces near Banff.

The last hypothesis would ultimately remobilize fluids from the Infracambrian aquifer during Eocene extension, if they were not yet entirely dewatered, with upward migration of deep, hot hydrothermal fluids toward already compacted and schistose overlying Paleozoic formations (Fig. 13d). Similar fluid migration from a deep siliciclastic aquifer toward shallower carbonate successions and related diagenesis has been recently studied in detail on both sides of a high-angle basement-involving normal fault, namely the Uzer Fault in the Ardèche margin of the French Alpine foreland (see Bonijoly et al., 1996; Léost et al., 1995, 1998; Léost, 1998; Ramboz et al., 1999; and references therein).

Whatever scenario is invoked, the zebra dolomites are explained by focused fluid flow which in the Canadian case especially, took place near a former paleo-geographic transition of basinal shale-dominated lithologies towards platform edge carbonates (Aitken, 1971). The fact that fluids along this contact also gave rise to the Kicking Horse and Monarch MVT-mineral deposits supports the hypothesis that this paleo-geographic transition is a place of localized fluid flow (Swennen et al., 2003b).

\subsection{Fluid Conduits, Lateral and Vertical Mg Transfers and Development of Saddle Dolomite}

The transfer of chemical elements such as $\mathrm{Mg}$ (and sometimes Fe) from an exotic source is obvious in the case of the late ferroan dolomitization of a reservoir, but also in the development of some carbonate cements in coeval fractures. Saddle-dolomite crystals can usually be detected directly in thin-sections and by using cathodoluminescence imagery.

High temperature dolomitization of carbonate reservoirs, resulting in the development of saddle dolomite and coeval secondary porosity development, occurs due to major fluid migration in areas of active tectonics (Mountjoy et al., 1992; Machel et al., 1996; Wendte et al., 1998; Swennen et al., 2002, 2003a; Al-Aasm and Clarke, 2004). When saddle dolomite is not a cement but replaces limestone, e.g., in the mesodolomites, dolomitization accounts for an improvement of reservoir characteristics, because the transformation of calcite into dolomite can induce a significant volume change.

$\mathrm{Mg}$ is likely derived from the compaction and diagenetic transformation of (nearby) shaley strata, or it can be transferred from the basal décollement when this is located in evaporitic layers.

However, the volume of the reservoir that can be improved by such hydrothermal enhancement is directly related to the ability of the circulating fluids to reach the host rock matrix. This is usually controlled by the distribution of major high-angle fractures, as observed in Provence (de Charpal et al., 1959), or by the sedimentology, i.e., the 

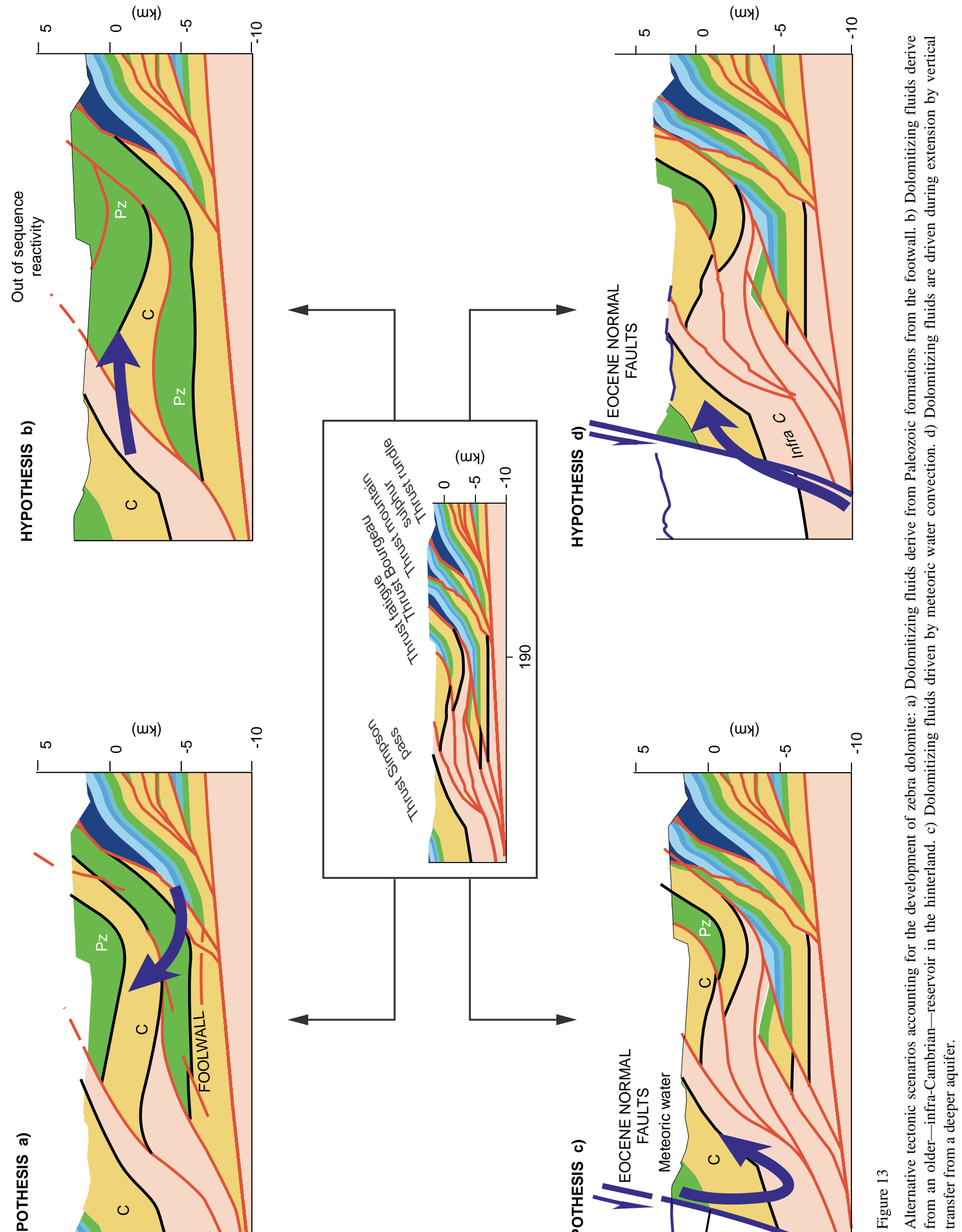
distribution of reefs and early dolostone in intra-platformal domains in the Devonian carbonates of Alberta (e.g., at Pine Point; Mountjoy et al., 1992; Wendte et al., 1998).

Quantitative prediction of secondary dolomitization in a given reservoir can now be modelled by coupling basin modeling output data such as temperature and velocity of fluid flow with forward diagenetic processes, provided that regional petrographic-sedimentological-hydrologic studies can be used to propose a realistic initial mineralogic assemblage, as well as estimates of the composition of the migrating fluids. Mass balance is also quite important, and the volume of fluids required to bring $\mathrm{Mg}$ into the reservoirs most likely constitutes one of the most critical parameters controlling the amount of the transformation and the extent of the dolostone body. Tectonics constitutes one key to the natural system, controlling the instantaneous opening and vertical permeability of fractures, and the degree to which a given reservoir will react as an open system for the dolomitizing fluids.

\section{THRUST-RELATED DEVELOPMENT OF VUGGY POROSITY}

Vuggy porosity provides excellent storage for petroleum and to generate unusually high permeabilities in Mississippian carbonate reservoirs in the Canadian Cordillera. For instance, in some mesodolomites of reef debris talus deposits of the Cairn Formation, macroporosity and vugs occur due to the dissolution of non-dolomitised stromatoporoids and tabulate corals (Fig. 14a). If this porosity had been created before thrust emplacement, one would expect to find places where some collapse and brecciated geopetal structures became associated with the up to $30 \mathrm{~cm}$ large cavities. Furthermore the first calcite cement phases partially filling up some of the cavities and biomolds possess $T_{h}$ fluid inclusion values $>100^{\circ} \mathrm{C}$. Also, in the matrix dolomites some important intracrystalline biomold porosity occurs in relation to the preferential dissolution of relict calcite. Here host rock dolomitisation was selective, mainly affecting the micrite in wacke- and packstones, while larger fossil fragments such as crinoids were not dolomitized. The latter calcite fragments became subsequently dissolved. This porosity is thought to have developed due to "cooling of formation waters" or in relation to "host rock cooling". An alternative scenario is dissolution due to fluid mixing, again induced by tectonic uplift.

In the first scenario (e.g., Giles and de Boer, 1989), it is assumed that fluids which eventually were in equilibrium with calcite, when channelled along faults and subsequently entering a calcite-bearing dolomite, will have the potential to dissolve calcite and thus create porosity. This assumes that the fluids do not react with carbonate-bearing rocks along their ascent.
The model of "host-rock cooling" requires the same chemical constraints as the previous scenario. However, here it is assumed that the cooling is due to the tectonic uplift and coeval erosion of a structural element during thrust emplacement (Fig. 14b). This uplift and unroofing often occur at the middle stage of thrusting and would cool down the entire rock unit, including its formation waters. This would generate an important potential for the dissolution of calcite and the generation of vugs. CERES modeling of the Canadian transect shows that fluid velocity is greatest in the underthrust footwall during a short interval (compressiondriven squeegee episode of fluid expulsion). Reservoir strata remain dominantly a closed system from the onset of thrusting onward, thus further supporting the hypothesis of "host-rock cooling". In addition, it can also be assumed that meteoric fluids can infiltrate and mix with the "cooled" formation waters, thus improving the potential to dissolve up to $10 \%$ of the non-dolomitized calcite (e.g., Esteban and Taberner, 2003).

Why the dolomite is not dissolved remains undetermined. However as reported by Giles and de Boer (1989) the degree of saturation with respect to calcite (and dolomite) of cooled formation waters is strongly dependent on $\mathrm{pH}$ and bulk chemistry and thus, it is likely that a scenario exists where calcite might dissolve while dolomite is not affected. However, some diagenetic modeling should be performed to confirm this scenario. Another scenario that could be invoked is the dissolution of calcite by acidic fluids or $\mathrm{H}_{2} \mathrm{~S}$ generated during the maturation of hydrocarbons (Giles and Marshall, 1986) or subsequent thermo-chemical sulfate reduction. This scenario is supported by the presence of depleted $\mathrm{CO}_{2}$ in the subsequent cementation of the calcites which occur in the macropores. This scenario has also been invoked at other places in the Canadian Cordillera with convincing arguments by Machel (1987).

\section{IMPACT OF HYDROCARBON CHARGE ON RESERVOIR CHARACTERISTICS, AND HOW ID- AND 2D-MODELING CAN PREDICT RESERVOIR PERFORMANCE}

Petroleum entrapped within the matrix porosity of sandstone reservoirs and in hydrocarbon-bearing fluid inclusions in diagenetic mineralizations are indicative of the history of the regional petroleum system (e.g., Haszeldine et al., 1984; Guilhaumou et al., 2004). The composition of several generations of hydrocarbon fluid inclusions recognized provides information on the paleo-maturity of oil and coeval hydrocarbon kitchens, and composition of migrating $\mathrm{HC}$ at each step of diagenesis. The amount of $\mathrm{CH}_{4}$ as well as additional components present in the oil, e.g., $\mathrm{CO}_{2}$ and $\mathrm{H}_{2} \mathrm{~S}$, and mixing with water, as recognized in representative fluid inclusions, have an impact on the chemistry of the whole 


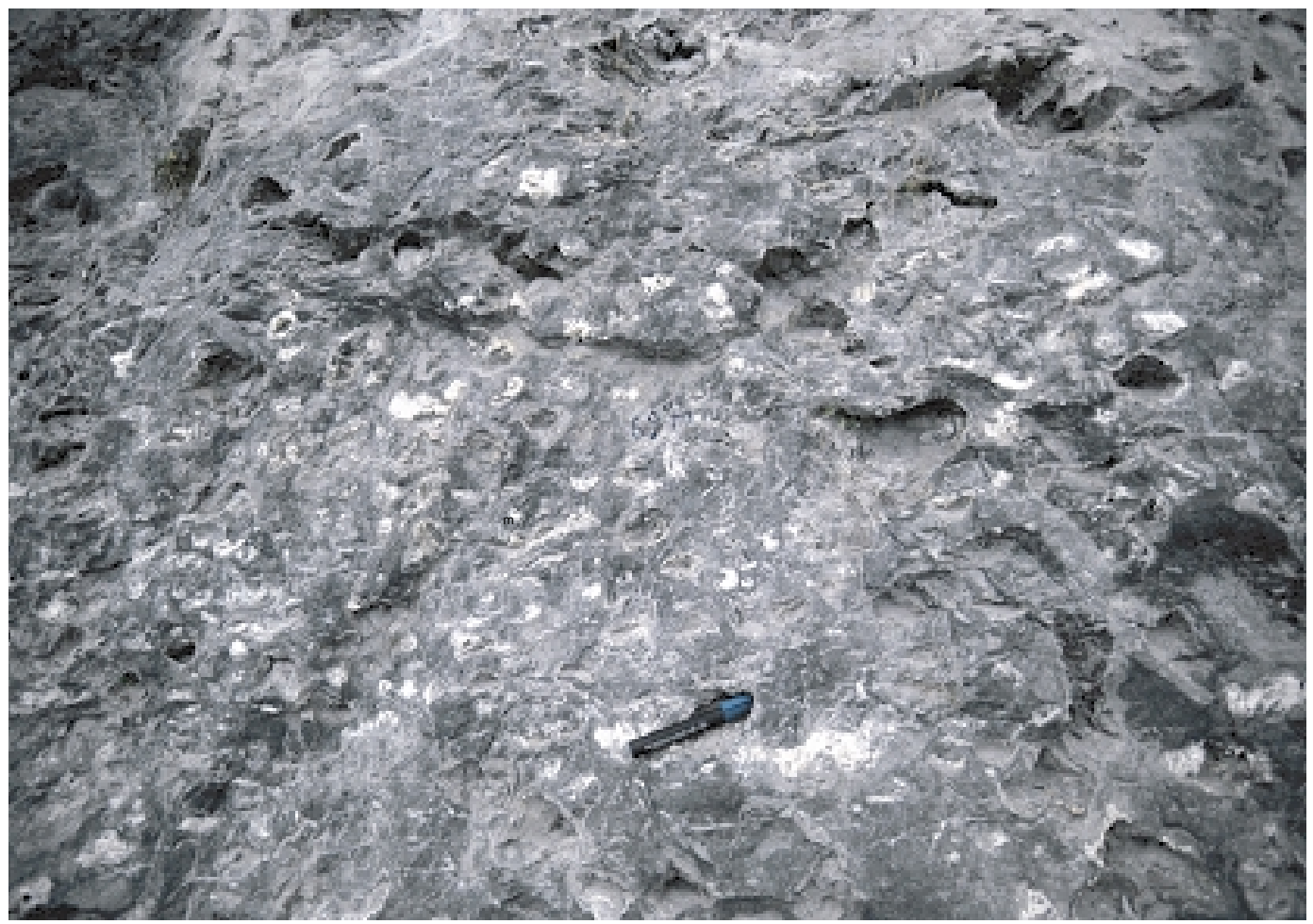

\section{Mississippian Burial history}

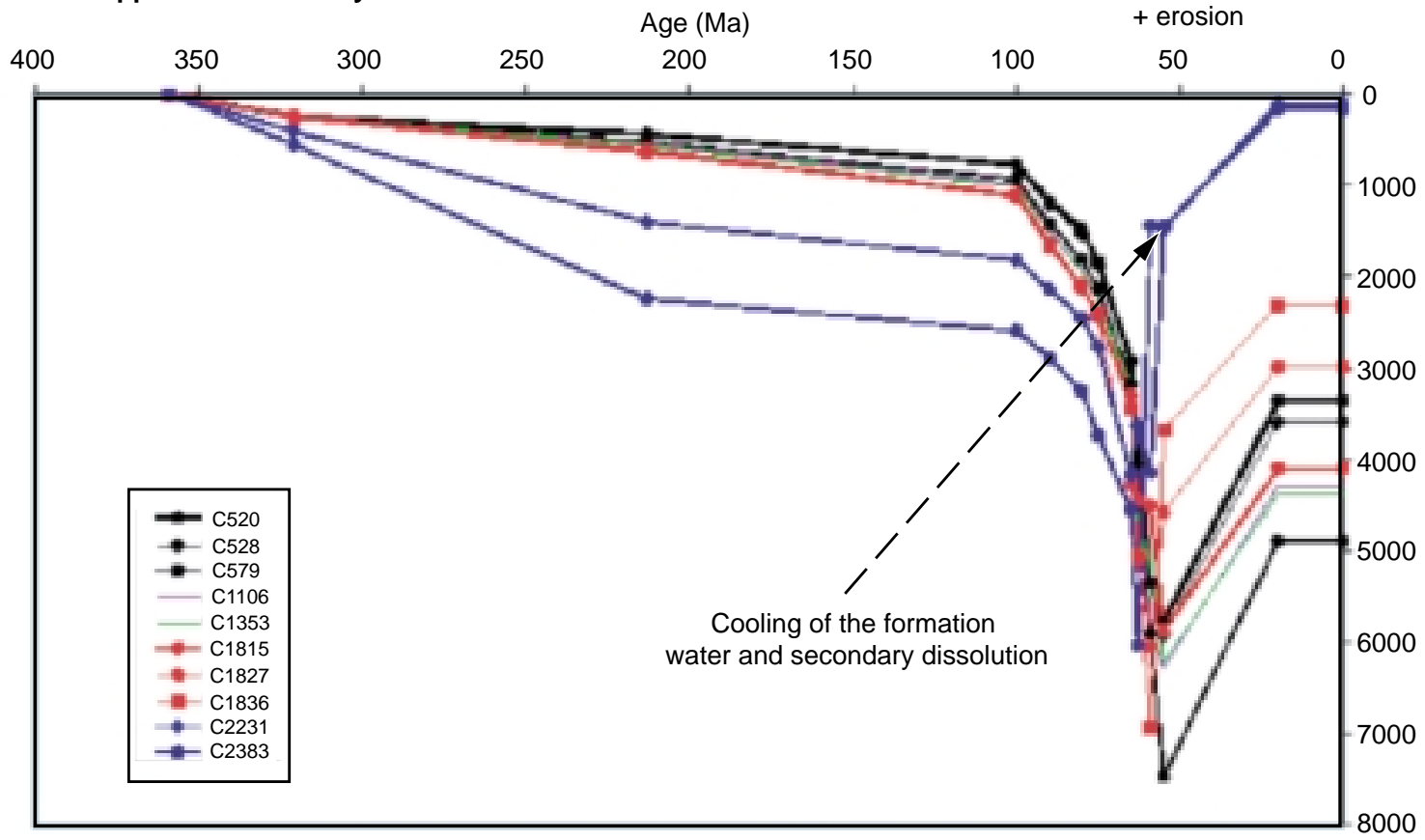

Figure 14

Schematic diagram outlining the effect of tectonic uplift and erosion on the P-T evolution of carbonate reservoirs. Notice the huge vuggy porosity that developed in Mississippian carbonates of the Cairn Formation during thrust related uplift and formation cooling. 
system. Inclusions filled by $\mathrm{CO}_{2}$-enriched oil systematically display precipitated asphalten, thus recording subsequent pressure and temperature decrease after trapping in mineralized (fluorite-bearing) veins of Pakistani and Tunisian foothills (Guilhaumou et al., 2000; Benchilla, 2003; Benchilla et al., in press). In Baluchistan fluorite deposits (Pakistan), oil degradation occurred by secondary water influx (Benchilla, 2003). Fluid inclusions also help to define increase and decrease of trapping temperatures, and the timing of the main diagenetic events (Fig. 9).

In some cases, hydrocarbon fluids may also inhibit additional quartz cementation in the reservoir.

Alternatively, biodegradation, pressure changes and insitu heating of early entrapped hydrocarbons may result in the formation of heavy products such as bitumen, asphaltenes or pyrobitumen, which may alter the total producibility characteristics of foothills reservoirs. Seemingly, the large amount of $\mathrm{CO}_{2}$ coming from organic matter and decarbonization processes play a significant role in the precipitation of asphaltenes, especially in MVT-types of mineralizations and carbonate reservoirs (i.e. in Tunisia and Pakistan; Guilhaumou et al., 2000; Benchilla et al., 2003).

\subsection{Oil-Anhydrite Interactions and Thermo-Sulfate Reduction in FFTB}

Thermochemical sulfate reduction (TSR) is a process observed in many geological settings where anhydritebearing petroleum reservoirs have been deeply buried. The association of sulfates and organic matter in sediments is thermodynamically instable. It is generally accepted that the TSR process, where petroleum compounds such as branched and $n$-alkanes but also anhydrite react to form calcite, $\mathrm{H}_{2} \mathrm{~S}$, water and other minor components, usually takes place above a temperature of $100-145^{\circ} \mathrm{C}$ (Orr, 1974; Pierre and Rouchy, 1988; Worden et al., 1995; Machel et al., 1995). However, Machel (2001) considers that TSR does not require a sharply defined minimum temperature and may eventually start even at $80^{\circ} \mathrm{C}$, a temperature at which Bildstein et al. (2001) indicated that TSR-related chemical reactions can be effective over a short time. In the Western Canadian Sedimentary Basin isotopic data show that anhydrite with $\delta^{34} S$ values typical of Devonian seawater is the main sulphur source in Devonian reservoirs. The same is the case in Mississippian succession, suggesting that although the migration of $\mathrm{H}_{2} \mathrm{~S}$ may occur after TSR, the amount does not drastically affect the local sulfate source signal (Krouse et al., 1988; Machel et al., 1995). This points towards a relatively closed diagenetic system. There has been some discussion regarding the importance of TSR in secondary porosity creation. Hutcheon et al. (1993) showed that about $75 \%$ of the space volume created by anhydrite dissolution becomes subsequently filled by calcite derived from the TSR-reaction. However, the $\mathrm{H}_{2} \mathrm{~S}$ generated during TSR can migrate away from the reaction site and become dissolved in water. This weak acid can cause dissolution, but significant secondary porosity development would require huge volumes of $\mathrm{H}_{2} \mathrm{~S}$ to be produced.

In the foreland fold-and-thrust belts studied in the SUBTRAP-project, i.e., the Canadian Cordillera along the trans-Canadian highway 1, and the Pakistani foothills in the Eocene Chorgali setting of the North Potwar Deformed Zone, and more specifically in the adjacent Dakhni field, there are a number of features that help to recognize TSRrelated diagenesis. Calcite rimming anhydrite nodules is a good indicator. This calcite, which clearly is a late diagenetic product, is depleted in $\delta^{13} \mathrm{C}(<-20 \%)$, has a bright yellow luminescence and formed time-equivalent with pyrite. Locally native sulfur occurs as a reaction product, and some authors suggest that saddle dolomite can be associated with TSR (Machel, 1987). Also time-equivalent secondary porosity development is likely to occur near TSR locations. Fluid inclusions, collected from carbonate phases in relation with TSR contain $\mathrm{H}_{2} \mathrm{~S}, \mathrm{H}_{2} \mathrm{O}, \mathrm{CO}_{2}$ and $\mathrm{C}_{1}-\mathrm{C}_{3}$ hydrocarbons. Furthermore, fluid inclusion waters have low salinity, and have isotopically heavier oxygen than formation waters, suggesting a mineral source which is explained by the fact that the oxygen released from anhydrite is the oxygen source for the water giving rise to the carbonate phases (Hutcheon $e t$ al., 2000). TSR consumes complex hydrocarbons, due to reaction kinetics (Hanin, 2002). This, combined with high thermal maturities, might explain the selective enrichment of methane in most of the gas reservoirs affected by TSR.

Detailed fluid inclusion and isotope studies and coupled petroleum modeling helps to define two successive episodes of hydrocarbon (HC) migration and fluid rock interactions in cemented fractures of the Chorgali Eocene carbonate outcrops of Chorgali Pass in the North Potwar Deformed Zone in Pakistan, thus providing a way to correlate the timing of TSR development and reservoir damaging in the anticlines with coeval maturity evolution of source rocks in adjacent synclines (Benchilla et al., 2003; Guilhaumou et al., 2004; Figs. 15 and 16):

- Onset of quartz and calcite precipitation in the fracture system of the Eocene carbonate occurred during lower Siwalik time, 15 to $10.8 \mathrm{Ma}$ ago, when the reservoir was already buried at more than $1.5 \mathrm{~km}$ at temperatures close to $75-85^{\circ} \mathrm{C}$ and $150-180$ bar, synchronously with first hydrocarbon-bearing fluid inclusion (FI) entrapment and onset of replacement of sulfate by calcite.

- Peak oil generation and migration occurred later, from 10.8 to $5.7 \mathrm{Ma}$, when the reservoir was buried at more than $4 \mathrm{~km}$, accounting for a second generation of more mature $\mathrm{HC}$-bearing fluid inclusions depleted in $\mathrm{CO}_{2}$ and enriched in $\mathrm{CH}_{4}$, having trapping temperatures comprised between 125 and $140^{\circ} \mathrm{C}$, synchronous with late quartz precipitation.

- Hydraulic veins display low $\delta^{18} \mathrm{O}$ values ( -7.8 to $-14.1 \%$ ) which represent high temperatures of recrystallisation for 


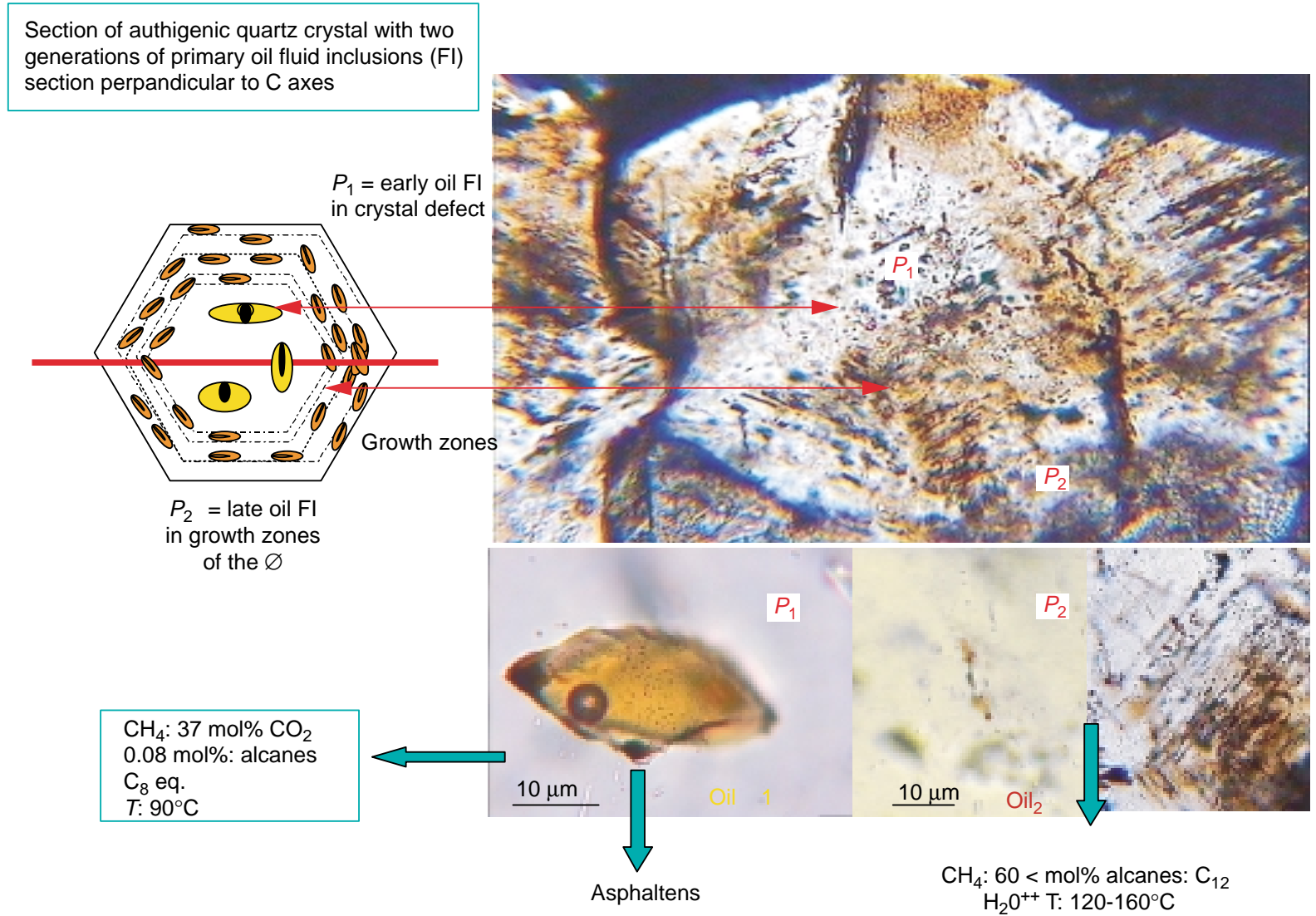

Figure 15

Authigenic quartz containing different sets of oil-bearing fluid inclusions, recording successives episodes of oil migration and TSR in Eocene fractured carbonates of the Chorgali Formation, Chorgali Pass, Pakistan.

calcite from low salinity water, i.e. 90 to $150^{\circ} \mathrm{C}$, with also low $\delta^{13} \mathrm{C}$ values ( -7.8 to $-14.6 \%$ o) in calcite veins, thus indicating the conditions for TSR.

Both the first and second generations of hydrocarbonbearing FI are primary inclusions, and assumed to be in thermal equilibrium with the overburden, whereas $\mathrm{HC}$ are likely to come laterally from deeper horizons, in areas where the source rocks actually reached the oil window. The origin of $\mathrm{CO}_{2}$ in first $\mathrm{HC}$ migration pulse may come from decarbonatation of early calcite or from the decomposition of the organic matter (Type III). High content of $\mathrm{CH}_{4}$ and $\mathrm{CO}_{2}$ depletion for the second generation of hydrocarbon-bearing fluid inclusions also suggest a reducing environment, timeequivalent with TSR.

The Eocene Chorgali carbonate is the productive reservoir in the nearby Dakhni field, where gas-condensate is produced with $\mathrm{H}_{2} \mathrm{~S}$. All other fields in the Potwar Basin lack $\mathrm{H}_{2} \mathrm{~S}$ and produce oil from either Jurassic sandstone (Datta Formation) or older carbonate reservoirs lacking anhydrite. 1D- and 2Dpetroleum modeling demonstrates that the Potwar Basin is an oil-prone rather than a gas province and that TSR is the primary reason why the anhydrite-rich Chorgali reservoir produces $\mathrm{CH}_{4}$ and $\mathrm{H}_{2} \mathrm{~S}$ instead of oil.

Since TSR can lead to the complete destruction of petroleum, much effort has been made to model the effects of TSR. Based on forward kinematic modeling it is possible to define those areas in foreland fold-and-thrust belts that are more vulnerable to TSR. Diagenetic modeling subsequently helps to refine the effects on reservoir. Here the ratecontrolling step of TSR evolves initially from:

- the rate of aqueous redox interaction between sulfate and petroleum to

- the rate of diffusion-controlled dissolution of anhydrite.

According to Bildstein et al. (2001) this might explain the high minimum temperature of the reaction as well as the coexistence of anhydrite and petroleum even in reservoirs where TSR is advanced.

\subsection{Hydrocarbon Circulation and Secondary Dissolution along Stylolitic Planes}

What type of fluid caused the porosity development along both horizontal and vertical stylolites in upper Cretaceous 

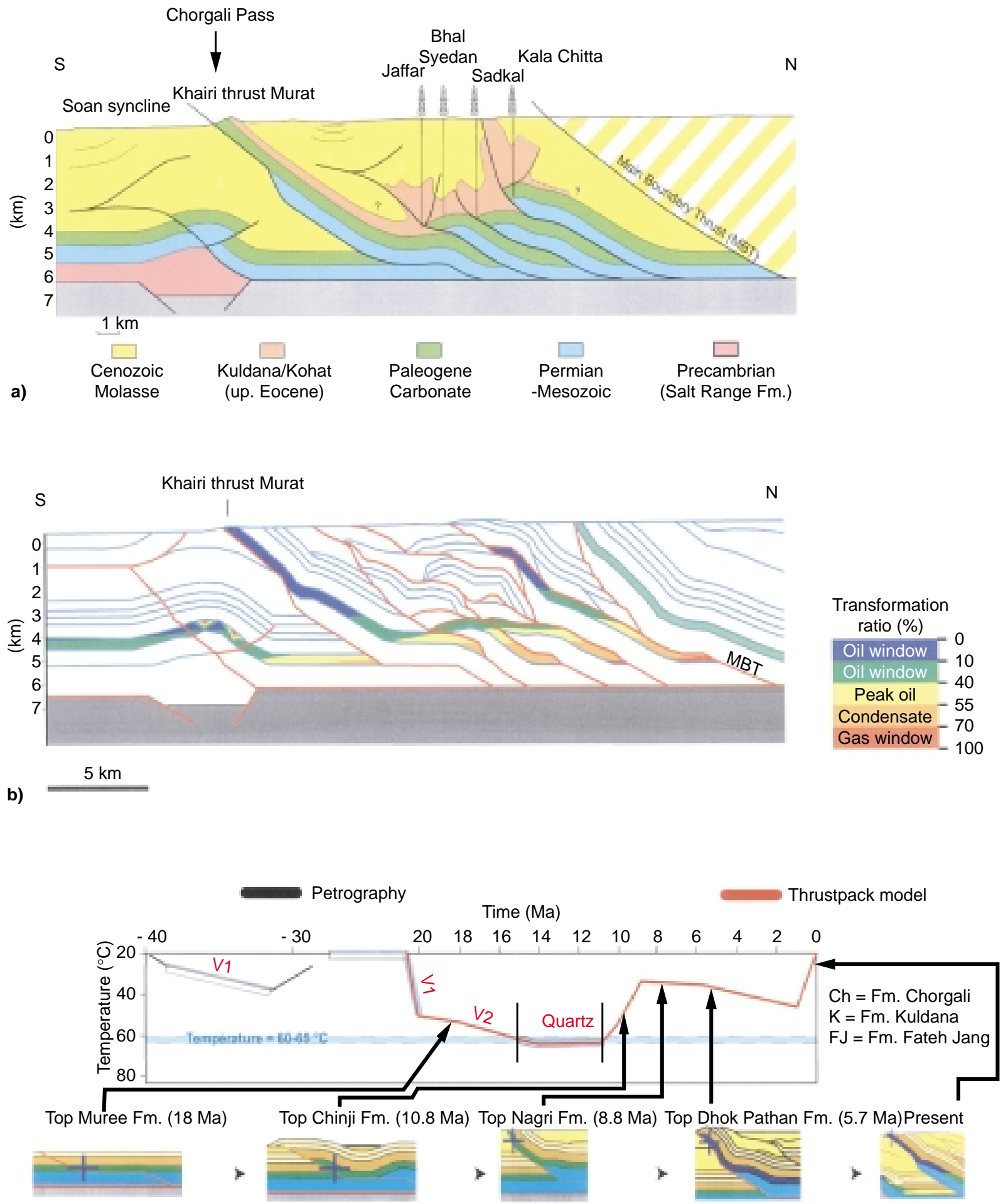

c)

Figure 16

Results of a Thruspack simulation across the Khairi Murat Thrust along the Central SUBTRAP Pakistani transect (see location in Figure 1e), providing age constraints on the timing of quartz-cementation in cemented fractures of an outcropping Eocene Chorgali reservoir analogue and hydrocarbon trapping (after Benchilla, 2003): a) Present-day geometry of the section. b) Present distribution of maturity windows, as computed with Thrustpack. c) Temperature versus time evolutionary diagram for the studied Chorgali outcrop. $T_{h}$ temperatures $\left(60-65^{\circ} \mathrm{C}\right)$ measured in the fluid inclusions in the quartz cement plot at about 14-12 Ma, assuming the migrating fluids were at the thermal equilibrium with the overburden. 
a) CUSIANA-type burial history (Colombian foothills)

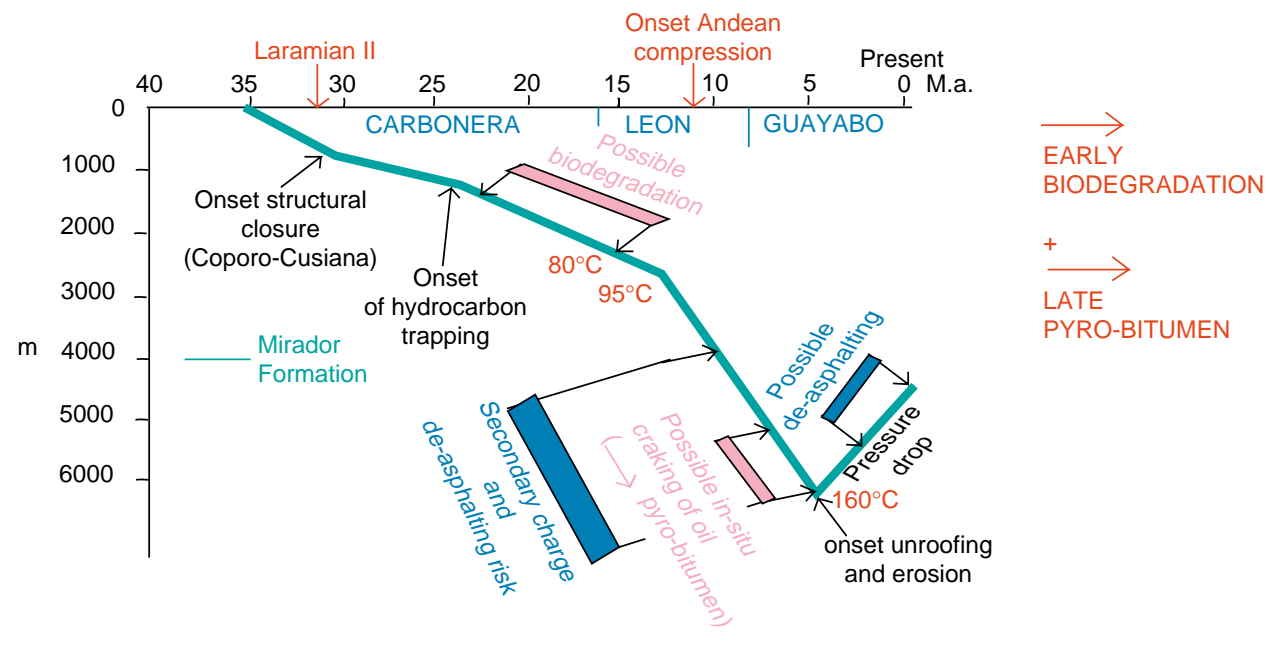

b) EL FURRIAL - type burial history (Eastern Venezuela)

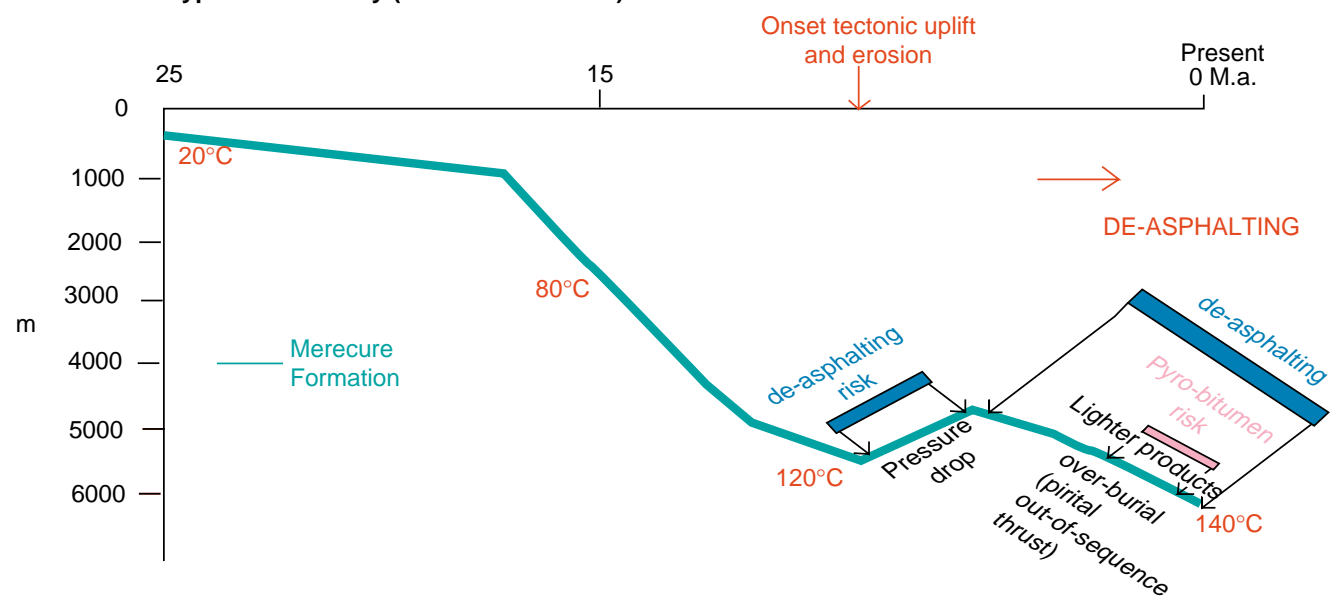

c)PIRITAL- type burial history (Eastern Venezuela)

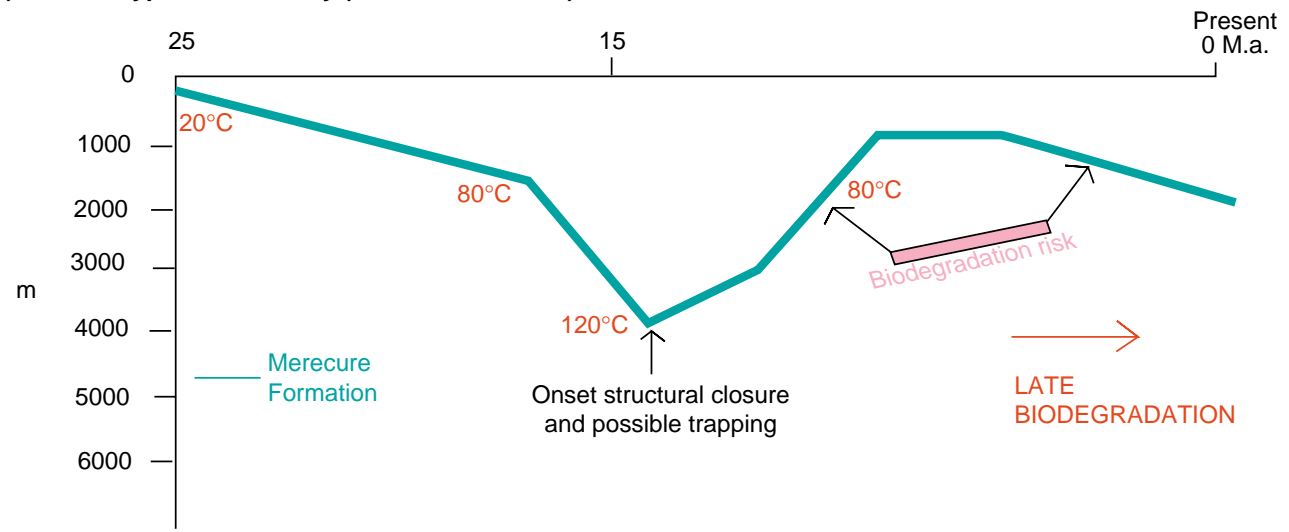

Figure 17

Burial-temperature curve of Sub-Andean sandstone reservoir prospects, indicating episodes of potential risk of biodegradation, pyrobitumen and deasphalting (see location of the wells and fields in figures 1a and 1b): a) Early charge in Cusiana field (Colombia) resulted in biodegradation when the reservoir temperature was still lower than $100^{\circ} \mathrm{C}$. Increasing burial resulted in subsequent charge with lighter, more mature hydrocarbon, resulting in a mixing of different oils. b) Recent uplift and erosion account also for thermodynamic disequilibrium and deasphalting in Colombian and Venezuelan foothills (see Cusiana and El Furrial trends). However, increasing burial after trapping may also account for pyrobitumen development in Eastern Venezuela (see El Furrial trends). c) Ultimately, uplift may result also in drastic cooling of the reservoir, allowing biodegradation to resume (see Pirital-Quiriquire trends). 
pelagic carbonates and interbedded turbidites of the Ionian basin in Albania and similar settings elsewhere is unclear, neither is its timing exact. However, it is obvious that it postdates LPS-stylolite development. An important additional observation is that matrix dissolution has not been observed along any of the already cemented vein systems studied. Furthermore dissolution seems to be restricted to oil-stained stylolites and to the adjacent matrix (e.g., enlarged biomolds close to stylolites). Therefore, it seems likely that dissolution might be related to the migration of acid fluids which are linked to the hydrocarbon maturation history, as proposed by Schmidt and MacDonald (1979) and Surdam et al. (1984). However, Giles and Marshall (1986) and Giles (1997) pointed to the important buffering capacity of the carbonate host rock. This might explain why dissolution is essentially restricted to the stylolites.

Why these aggressive fluids did not enter the porous Albanian turbidites, even in the large pores and thus, did not enhance the matrix porosity, is not clear. A possible explanation is that the Albanian turbidites and the open joints became rapidly oil charged while in the tighter strata the aggressive fluids preferentially circulated along rock heterogeneities, such as stylolites. Within these nearly impermeable strata, migration was very slow, permitting dissolution to take place. Thus reaction time is advocated as a possible explanation for the observations.

\subsection{Successive Trapping Episodes, Deasphalting and Permeability Reduction}

In numerous foothills prospects, the total permeability of subthrust reservoirs is drastically reduced due to the occurrence of pyrobitumen, tars and asphaltenes. However, numerous hypotheses can be proposed to account for the distribution of these heavy products (Fig. 17):

- Pyrobitumen may occur due to the in situ cracking of early entrapped hydrocarbons during episodes of burial and temperature increase (pyrobitumen).

- Tars may also occur due to biodegradation.

- Finally, heavy products can result from deasphalting processes induced by changes in the pressure of the reservoir. Effectively, major thermodynamic changes may affect the reservoir when a mixing of early entrapped and later hydrocarbons or $\mathrm{CO}_{2}$ occurs, or when the load of the overburden is decreased by erosion.

\subsubsection{Migration Pulses and Deasphalting}

Due to differences in burial, distinct source rock intervals of the sedimentary succession will enter the crude oil or natural gas windows at different times. Alternatively, a single source rock interval will generate and expel different petroleum compounds through time. As a result, the history of hydrocarbon trapping can become very complex in a specific setting.

The late arrival of natural gas or light hydrocarbons within already or partially filled reservoirs will induce a thermodynamic disequilibrium in the early entrapped hydrocarbons, eventually resulting in the gravitational sedimentation of the heavy compounds (deasphalting).

\subsubsection{Tectonic Uplift, Erosion and Deasphalting}

Tectonic uplift and coeval erosion of surface anticlines may also decrease the fluid pressure within the matrix porosity of underlying reservoirs in the case of an open system, i.e. when the pore pressure is approximately hydrostatic. Alternatively, pore pressure may also decrease during erosional episodes in a closed system, due to the elastic rebound of the sedimentary grains. In both cases, the resulting thermodynamic disequilibrium would lead to deasphalting.

\subsubsection{How to Evaluate the Deasphalting Risk in FFTB?}

The study of entrapped crude oils (organic geochemistry) and hydrocarbon-bearing fluid inclusions may help in identifying the successive migration pulses that resulted in the mixing of different petroleum phases within a given reservoir. However, these analytical studies can only be performed after drilling, and do not aid prediction.

Instead, reliable prediction of:

- the composition of successive hydrocarbon phases expelled by source rocks;

- the burial evolution of reservoirs can be attempted by 1D and 2D basin modeling, even for tectonically complex foothills prospects (Roure and Sassi, 1995; Schneider, 2003; Faure et al., 2004; Roure et al., 2003, 2004; Schneider et al., 2004; Toro et al., 2004).

Assuming the migration pathways between source areas and a given prospect are reasonably well constrained, basin modeling can help predicting the degree and timing of mixing of light versus heavy hydrocarbons within a given reservoir. Provided the timing and amounts of erosion are sufficiently well constrained, it is possible to approximate the reduction of pore-fluid pressure within the matrix porosity of the reservoir for successive episodes of uplift (ultimately, a minimum value of this pressure decrease in a hydrostatic regime, that would equal the load of a water column equivalent to the eroded formations).

Fluid inclusion studies and coeval PVT reconstructions may also provide accurate records of former pore fluid pressures. Thus, when compared with the burial and temperature curves of the reservoir, as derived from backstripping, these data can help determine whether the reservoir evolved close to lithostatic, hydrostatic or in the intermediate overpressured regime.

Late injection of $\mathrm{CO}_{2}$ into previously entrapped oil reservoirs is likely to occur in mature FFTB or in volcanic 
provinces. $\mathrm{CO}_{2}$ entrapped in natural reservoirs may also come from the thermal evolution of the organic matter itself. No matter its origin, natural $\mathrm{CO}_{2}$ injection in reservoirs is one of the main processes accounting for deasphalting by segregation of heavy products. In carbonate reservoirs, the study of dissolution-recrystallisation process and mechanism such as the thermo-sulfate reduction (TSR) by coupled analytical and chemical modeling approach is the best way to make a predictive risk analysis (Bildstein et al., 2001).

\subsection{Burial Increase and the Pyrobitumen Risk in FFTB}

Early entrapped hydrocarbons may still be involved in episodes of increasing burial and heating, resulting in the in situ cracking of crude oil into pyrobitumen, which in turn contributes to a reduction of total reservoir permeability.

Pyrobitumen can be observed in reservoir samples during Rock-Eval pyrolysis by its specific oxidization temperatures, which are quite high compared to asphaltenes and other heavy products. Intermediate oxidization temperatures of approximately $600^{\circ} \mathrm{C}$ have been measured in Colombia, specifically in the Eocene Mirador reservoir in the Coporo well which penetrates the footwall of the Guavio-Agua Clara thrust (Fig. 1), and could be related to pyrobitumen occurrence. In contrast, bitumen in the Cusiana field, still in the Colombian foothills (Fig. 1), is rather indicative of early episodes of hydrocarbon charge and biodegradation, predating the recent episodes of tectonic burial of the Mirador sandstone beneath the Yopal thrust (Cazier et al., 1995; Warren et al., 1998; Warren and Pulham, 2001).

Again, 1D and 2D basin modeling tools may be useful for the prediction of pyrobitumen in FFTB, as well as for the prediction of the time of oil expulsion and trapping, and the new temperature of a given reservoir, when it has undergone successive episodes of tectonic or sedimentary burial.

\subsection{Oil-Water Interactions and Biodegradation in FFTB}

Pressure decrease and temperature increase are not the only processes that lead to the segregation of heavy products, pyrobitumen occurrences and related damaging of the reservoir permeability in foothills areas. Biodegradation of entrapped crude oils, when in contact with meteoric water at temperatures $<80^{\circ} \mathrm{C}$, may also account for a progressive increase of the density of the crude oil.

\subsubsection{Foreland Tar Belts}

Biodegradation processes account for huge accumulations of tars in the Athabasca bitumen (lower Cretaceous Mannville Formation sandstones) in the Western Canada Sedimentary Basin, and to the Orinoco Tar Belt in Eastern Venezuela, where long distance migrated hydrocarbons originating farther north in the Serrania Foothills became locally entrapped updip at the regional flexure, at a very shallow depth in Neogene sandy reservoirs. In the latter case however, the porosity and permeability reduction due to the bitumen occurrence constitutes a very efficient seal preventing lighter hydrocarbons from escaping to the surface.

\subsubsection{Occurrence of Biodegraded Hydrocarbon Products in the Foothills}

In addition to modern erosional processes and recent biodegradation in shallow prospects, early deformation may also contribute to the local biodegradation of early entrapped hydrocarbons in reservoirs that are currently buried at great depth and high temperatures. This is the case in the Cusiana trend in Colombia (Cazier et al., 1995; Warren et al., 1998; Warren and Pulham, 2001). Thus, during the Eo-Andean inversion episode, burial was low enough to put early entrapped hydrocarbons in contact with relatively cold meteoric water. During subsequent Neogene burial and ongoing compression, the reservoir temperature increased and a new, non-biodegraded hydrocarbon phase became entrapped. As a result, hydrocarbon products currently stored in this subthrust reservoir are a mixture of heavy and old biodegraded compounds, and younger, well preserved products of a more recent migration pulse. This is the case also in the Patos field in Albania, where surficial biodegradation in Messinian sandstone reservoirs accounts for the development of bitumen, which constitutes an efficient seal for underlying, lighter hydrocarbons remigrated from underlying Mesozoic carbonate duplexes along the basal unconformity of a Neogene piggyback basin (Roure et al., 2004).

\subsubsection{How to Predict the Occurrence of Biodegraded Products in FFTB Prospects?}

Because biodegradation can only occur below $80^{\circ} \mathrm{C}$, it is possible to use 1D and 2D basin modeling tools to reconstruct the burial curve of subthrust reservoirs, and identify the successive episodes for which the reservoir was at a temperature lower than this critical value (Fig. 17).

By reconstructing the history of maturation and expulsion of the source rocks and analysing the possible migration pathways for the hydrocarbons between the kitchen and the trap, it is also possible to determine when early migration pulses were likely to start filling a given prospect, and to predict whether hydrocarbons were already present in the reservoir at the time when unroofing and low temperatures occurred.

\section{CONCLUSIONS}

Case studies in numerous foreland fold-and-thrust belts help to demonstrate the controls exerted by global tectonics, individual tectonic events and coeval changes in the regional 
fluid flow regime on the overall reservoir characteristics of sandstone and carbonate formations. Both brittle (fracture) and penetrative (chemical pressure-solution) types of deformation are usually coeval to either cementation or dissolution processes. Main episodes of quartz cementation observed in the Sub-Andean foothills are directly connected to layer parallel shortening (LPS) in the footwall of major thrusts, probably with only limited migration of silica from the shaly interbeds. Evidently, LPS is the likely mechanism of major recrystallisation in dolostone in the Canadian Cordilleran Foreland Belt, even in areas where only limited fluid migration occurred. In contrast, secondary hydrothermal dolomitization of limestone formations will operate in an open system, which is required to bring $\mathrm{Mg}$ from underlying or adjacent shaley strata into the reservoir. Such high temperature secondary dolomitization can occur either in the fold belt itself, where vertical permeabilities are locally enhanced due to fracturing, or in the foreland, i.e., up-dip of the regional flexure, as indicated by the global habitat of Mississippi Valley Type ore deposits. Ultimately, thermodynamic changes such as P-T decrease occurring in carbonate reservoirs in the foothills are directly controlled by tectonic uplift and coeval erosion, and are sufficient to strongly modify the dissolution capacity of entrapped fluids, and to account for the development of vuggy porosity, even in a dominantly closed system.

Tectonic episodes directly control the access of exotic fluids into the reservoirs. Although the main source of silica in cemented Sub-Andean sandstones derives from pressuresolution among quartz-grains, the Eastern Venezuelan study has shown that main episodes of cementation occurred when both fluid circulation and thrusting were active, the circulating fluids being either buffered by the Oligocene series (first generation of quartz-overgrowths), or instead exotic and derived from Cretaceous aquifers of the Pirital allochthon. Hydrothermal dolomitization of carbonate reservoirs is also made possible in the allochthon when exotic fluids percolate verticaly along open/active fractures (i.e., during episodes of basin inversion and thrusting), as well as in the foreland, when compaction fluids are expelled laterally from the foothills toward the craton (i.e., during short-living squeegee episodes).

Regional integrated petrographic and basin modeling approaches help to specify the timing of individual episodes of cementation or dissolution, and to determine P-T conditions as well as the chemistry and velocity of the fluids circulating within the pore space of individual reservoirs of any petroleum prospect during its main diagenetic episodes. In carbonate reservoirs associated with evaporitic successions, mechanisms such as TSR may change local matrix porosity as well as fracture opening versus filling, especially in areas close to vertical fault conduits where a large influx of exotic fluids can occur.
Once the critical episodes of diagenesis of a given reservoir are identified, further diagenetic modeling can then be applied at a smaller scale, i.e., local reservoir, using the results of basin modeling as input data to compute the evolution of the porosity and mineralogical assemblage through times. As observed in the North Sea (Robinson and Gluyas, 1992; Walderhaug, 1996), individual natural episodes of reservoir cementation or dissolution are relatively short in Sub-Andean basins, the Canadian Cordilleran Foreland Belt and other FFTB, i.e., within 1 Ma or less, compared to other geological processes. Hopefully, the same type of integrated approaches that combine basin scale fluid flow and thermal modeling with local forward diagenetic simulations in individual structures and petroleum fields could be applied to shorter time intervals. This would provide the tools required to monitor the subsurface storage of $\mathrm{CO}_{2}$ or $\mathrm{H}_{2} \mathrm{~S}$.

Coupled tectonic, fluid flow and petroleum migration modeling in foreland fold-and-thrust belts can also help with the prediction of other exploration risks such as biodegradation, pore sealing, due to the deposition of bitumen, pyro-bitumen and asphaltenes, as well as the occurrence of $\mathrm{H}_{2} \mathrm{~S}$, due to thermochemical sulfate reduction (TSR).

In the future, further coupling of forward kinematic tools with rock mechanics are likely to provide a more efficient prognosis of tectonic compaction (LPS) and fracture development (Guiton, 2001; Guiton et al., 2003a, 2003b; Orlov et al., 2004), and to propose more realistic scenarios for the lateral and vertical evolution of permeabilities through times, to be applied during subsequent fluid flow modeling.

\section{ACKNOWLEDGEMENTS}

Most results discussed in this paper derive from the SUBTRAP (Sub-Thrust Reservoir Appraisal) research consortium operated by IFP from 1996 till 2001, in collaboration with the Universities of Paris-IV, CergyPontoise, Orsay, Leuven and Amsterdam, with the support of the Albanian Petroleum Institute, the Earth Sciences Sector/Geological Survey of Canada, BP-Colombia, Chevron, Conoco, Ecopetrol, Elf, Enterprise, Exxon, Fina, Gaz de France, IMP-Pemex, Intevep-PDVSA, Lasmo, OGDC, Premier Oil, Shell, Sipetrol and Total. Anna Travé and Étienne Brosse provided helpful reviews on the first version of the manuscript.

\section{REFERENCES}

Aitken, J.D. (1971) Control of Lower Paleozoic Sedimentary Facies by the Kicking Horse Rim, Southern Rocky Mountains, Canada. Bull. of Canadian Petrol. Geology, 19, 557-569.

Al-Aasm, I.S. and Lu, F. (1996) Multistage Dolomitization of the Mississippian Turner Valley Formation, Quirk Creek Field, Alberta: Chemical and Petrologic Evidence. In: Pangea: Global 
Environments and Resources, Glass, D.J., Beauchamp, B. and Embry, A.F. (eds.), Canadian Society of Petroleum Geology Memoir, 17, 657-675.

Al-Aasm, I.S., Lu, F. and White, T. (1996) Evolution of Pore Fluids and Dolomitization of Mississippian Carbonates of Western Canada Sedimentary Basin: Petrographic and Chemical Constraints. In: Alberta Basement Transect Workshop, Ross, G.M. (compilor), Lithoprobe Report, 51, 237-240.

Al-Aasm, I.S. and Packard, J.J. (2000) Stabilization of EarlyFormed Dolomite; a Tale of Divergence from Two Mississippian Dolomites. In: Paleofluid Flow and Diagenesis During Basin Evolution, Muchez, P. and Bechstaedt, T. (eds.), Sedimentary Geology, 131, 3-4, 97-108.

Al-Aasm, I.S. and Clarke, J.D. (2004) The Effect of Hydrothermal Fluid Flow on Early Diagenetic Dolomitization: an Example from the Devonian Slave Point Formation, NW Alberta, Canada. In: Deformation, Fluid Flow and Reservoir Appraisal in Forland Fold-and-Thrust Belts, Swennen, R., Roure, F. and Granath, J. (eds.), AAPG Hedberg Mem., 1, in press.

Allmendinger, R.W. (1998) Inverse and Forward Numerical Modeling of Thrishear Fault-Propagation Folds. Tectonics, 17, 4, 640-656.

Alvarez, W., Engelder, T. and Lowrie, W. (1976) Formation of Spaced Cleavage and Folds in Brittle Limestone by Dissolution. Geology, 4, 698-701.

Alvarez, W., Engelder, T. and Geiser, P.A. (1978) Classification of Solution Cleavage in Pelagic Limestone. Geology, 6, 263-266.

Aubourg, C. (1999) Une utilisation structurale de la fabrique magnétique. Thèse d'habilitation à diriger des recherches, University of Cergy-Pontoise, France.

Averbuch, O., Frizon de Lamotte, D. and Kissel, C. (1992) Magnetic Fabric as a Structural Indicator of the Deformation Path within a Fold-Thrust Structure: A Test Case from the Corbières (NE Pyrénées, France). Journal of Structural Geology, 14, 4, 461-474.

Bachu, S. (1999) Flow Systems in the Alberta Basin: Patterns, Types and Driving Mechanisms. Bulletin of Canadian Petroleum Geology, 47, 4, 455-474.

Benchilla, L. (1999) Test d'évaluation des paléo-champs de pression dans les séries sédimentaires des zones de foothills : les gisements d'Hamman Zriba (Tunisie) et de Koh-i-Maran (Pakistan). Master Thesis, IFP Report 53167.

Benchilla, L. (2003) Circulation des fluides et diagenèse des réservoirs carbonatés et gréseux dans les fronts des chaînes plissées et leur avant-pays: le cas du Salt-Range-Potwar (Pakistan). PhD Thesis, University of Leuven, Belgium.

Benchilla, L., Guilhaumou, N. Mougin, P., Jaswal, T. and Roure, F. (2003) Paleoburial and Pore Pressure Reconstruction of Reservoir Rocks in Foothills Areas: A Sensitivity Test in the Hammam Zriba (Tunisia) and Koh-I-Maran (Pakistan) Ore deposits. Geofluid, 3, 103-123.

Benchilla, L., Swennen, R., Roure, F. and Aktar, K. (in press) The Chorgali Reservoir in the Potwar Plateau and Salt Range, Indus Basin (N Pakistan): Integration of Litholog Modeling, Core Analysis and Outcrop Analogue Studies. Marine and Petroleum Geology.

Bildstein, O, Worden, R.H. and Brosse, E. (2001) Assessment of Anhydrite Dissolution as the Rate-Limiting Step during Thermochemical Sulfate Reduction. Chemical Geology, 176, 173-189.

Boles, J.R. and Franks, S.G. (1979) Clay Mineral Diagenesis in Wilcox of South-West Texas: Implication of Smectite Diagenesis in Sandstone Cementation. Jour. Sedimentary Petrology, 49, 55-70.

Bonijoly, D., Perrin, J., Roure, F., Bergerat, F., Courel, L., Elmi, S., Mignot, A. and the GPF Team (1996) The Ardèche Palaeomargin of the South-East Basin of France: Mesozoic
Evolution of a part of the Tethyan Continental Margin (GPF Géologie Profonde de La France-Programme). Marine and Petroleum Geology, 13, 6, 607-623.

Bordas-LeFloch, N. (1999) Diagenèse, compaction et déformation des réservoirs gréseux dans les chaînes plissées. $P h D$ Thesis, University of Paris VI.

Carnevali, J.O. (1988) El Furrial Oil Field, Northeastern Venezuela: First Giant in Foreland Fold-and-Thrust Belts of Western Hemisphere. American Association Petroleum Geologist Bull., 72, 68.

Cazier, E.C., Hayward, A.B., Espinosa, G., Velandia, J., Mugniot, J.F. and Leel, W.G. (1995) Petroleum Geology of the Cusiana Field, Llanos Basin Foothills, Colombia. American Association Petroleum Geologist Bull., 79, 1444-1463.

de Charpal, O.L., Montadert, L., Gubler, Y.G. and Rouge, P.E. (1959) Recherches sur les dolomitisations d'origine structurale. Fifth World Petroleum Congress, I, 3.

Cioppa, M.T., Al-Aasm, I.S., Symons, D.T.A., Lewchuk, M.T. and Gillen, K.P. (1999) Correlating Paleomagnetic, Geochemical and Petrologic Evidence to Date Diagenetic and Fluid Flow Events in the Husky Moose Reservoir, Alberta, Canada. Sedimentary Geology, 131, 109-129.

Cioppa, M.T. and Symons, D.T.A. (2000) Timing of Hydrocarbon Generation and Migration; Paleomagnetic and Rock Magnetic Analysis of the Devonian Duvernay Formation, Alberta, Canada. In: Proceedings of Geofluids III, Third International Conference on Fluid Evolution, Migration and Interaction in Sedimentary Basins and Orogenic Belts, Pueyo, J.J., Cardellach, E., Bitzer, K. and Taberner, C. (eds.), Journal of Geochemical Exploration, 69-70, 387-390.

Cioppa, M.T., Lonnee, J.S., Al-Aasm, I.S., Symons, D.T.A. and Gillen, K.P. (2001) Facies and Lithologic Controls on Paleomagnetism: an Example from the Rainbow South Field, Alberta, Canada. Bull. of Canadian Petroleum Geology, 49, 393407.

Cioppa, M.T., Al-Aasm, I.S., Symons, D.T.A. and Gillen, K.P. (2003) Dating Penecontemporaneous Dolomitization: Paleomagnetic and Geochemical Constraints. American Association Petroleum Geologist Bull., 87, 71-88.

Cioppa, M.T., Al-Aasm, I.S., Symons, D.T.A. and Gillen, K.P. (2004) Causes of Multiple Magnetizations in the Devonian "Upper" Member, Wabamum Group, Alberta, Canada: Fluid Flow and Diagenesis? In: Deformation, Fluid Flow and Reservoir Appraisal in Forland Fold-and-Thrust Belts, Swennen, R., Roure, F. and Granath, J. (eds.), AAPG Hedberg Mem., 1, in press.

Craddock, J.P. and Van der Pluijm, B.A. (1989) Late Paleozoic Deformation of the Cratonic Carbonate Cover of Eastern North America. Geology, 17, 416-419.

Dejonghe, L., Demaiffe, D. and Weis, D. (1998) Strontium Isotope Geochemistry of Anhydrites and Calcite Pseudomorphs after Anhydrite from Palaeozoic Formations in Belgium. Chemical Geology, 144, 1-2, 63-71.

Deming, D. and Chapman, D.S. (1989) Thermal Histories and Hydrocarbon Generation: Example from Utah-Wyoming thrust Belt. American Association Petroleum Geologist Bull., 73, 14551471 .

Deming, D., Nunn, J.A. and Evans, D.G. (1990) Thermal Effects of Compaction-Driven Groundwater Flow from Overthrust Belts. Journal Geophysical Research, 95, 6669-6683.

Dewever, B., Breesch, L., Swennen, R. and Roure, F. (in press) Marine Burial Diagenesis in Upper Cretaceous Turbidites (Central Albania). Submitted.

Enkin, R.J., Osadetz, K.G., Baker, J. and Kisilevsky, D. (2000) Orogenic Remagnetizations in the Front Ranges and Inner Foothills of the Southern Canadian Cordillera: Chemical 
Harbinger and Thermal Handmaiden of the Deformation. Geological Society of America Bulletin, 112, 929-942.

Erslev, E.A. (1991) Trishear Fault-Propagation Folding. Geology, 19, 6, 617-620.

Esteban, M. and Taberner, C. (2003) Secondary Porosity Development during Late Burial in Carbonate Reservoirs as a Result of Mixing and/or Cooling of Brines. Jour. Geochem. Explor., 78-79, 355-359.

Faure, J.L., Osadetz, K., Benaouali, N., Schneider, F. and Roure, F. (2004) Kinematic and Petroleum Modeling of the Alberta Foothills and Adjacent Foreland, West of Calgary. Oil \& Gas Science and Technology, Rev. IFP, 59, 1, 81-108.

Ferket, H., Ortuño-Arzate, S., Roure, F. and Swennen, R. (2003a) Lithology Control on Matrix Porosity in Shallow Marine Reservoir Limestones: Study of the Peñuela Reservoir Outcrop Analogue (Eastern Mexico). In: The Circum-Gulf of Mexico and the Caribbean: Hydrocarbon Habitats, Basin Formation and Plate Tectonics, Bartolini, C., Buffler, R.T. and Blickwede, J.F. (eds.), AAPG Mem., 79, Ch. 10, 283-304.

Ferket, H., Swennen, R., Ortuño-Arzate, S. and Roure, F. (2003b) Reconstruction of the Fluid Flow History during Laramide Foreland Fold-and-Thrust Belt Development in Eastern Mexico: Cathodoluminescence and $\delta^{18} \mathrm{O}-\delta^{13} \mathrm{C}$ isotope trends of calcitecemented fractures. Journal of Geochemical Exploration, 78-79, 163-167.

Ferket, H., Swennen, R., Ortuño-Arzate, S., Cacas, M.C. and Roure, F. (2004) Hydraulic Fracturing in the Laramide Foreland Fold-and-Thrust Belt of Eastern Mexico. In: Deformation, Fluid Flow and Reservoir Appraisal in Foreland Fold-and-Thrust Belts, Swennen, R., Roure, F. and Granath, J. (eds.), AAPG Hedberg Mem., 1, in press.

Frizon de Lamotte, D., Mercier, E., Dupré La Tour, A. and Averbuch, O. (1997) Cinématique du plissement et déformation interne des roches ; l'exemple du pli de Lagrasse (Aude, France). C.R. Acad. Sciences, 324, II a, 591-598.

Frizon de Lamotte, D., Mercier, E., Outtani, F., Addoum, B., Ghandriche, H., Ouali, J., Bouaziz, S. and Andrieux, J. (1998) Structural Inheritance and Kinematics of Folding and Thrusting along the Front of the Eastern Atlas Mountains (Algeria and Tunisia). In: Stratigraphy and Evolution of the Peri-Tethyan Platforms, Peri-Terthys Mem. 3, Crasquin-Soleau, S. and Barrier, E. (eds.), Mem. Museum National d'Histoire Naturelle, 177, 237-252.

Gallango, O. and Parnaud, F. (1995) Two-Dimensional Computer Modeling of Oil Generation and Migration in a Transect of the Eastern Venezuelan Basin. In: Petroleum Geology of South American Basins, Tankard, A.J., Suarez-Soruco, R. and Welsink, H.J. (eds.), AAPG Memoir, 62, 727-740.

Garven, G. (1985) The Role of Regional Fluid Flow in the Genesis of the Pine Point Deposits, Western Canada sedimentary basin. Economic Geology, 80, 307-324.

Ge, S. and Garven, G. (1989) Tectonically Induced Transient Groundwater Flow in Foreland Basins. In: The Origin and Evolution of Sedimentary Basins and their Energy and Mineral Resources, Price, R.A. (ed.), AGU, Geophysical Monograph Series, 48, 3, 145-157.

Ge, S. and Garven, G. (1992) Hydromechanical Modeling of Tectonically Driven Groundwater Flow with Application to the Arkoma Foreland Basin. Journal of Geophysical Research, B, Solid Earth and Planets, 97, 6, 9119-9144.

Ge, S. and Garven, G. (1994) A Theoretical Model for ThrustInduced Deep Groundwater Expulsion with Application to the Canadian Rocky Mountains. Journal of Geophysical Research, B, Solid Earth and Planets, 99, 7, 13.851-13.868.

Geiser, P.A. and Sansone, S. (1981) Joints, Microfractures and the Formation of Solution Cleavage in Limestone. Geology, 9, 280-285.
Giles, M.R. (1997) Diagenesis: a Quantitative Perspective. Implications for Basin Modeling and Rock Property Production, Kluwer Academic Publishers.

Giles, M.R. and Marshall, J.D. (1986) Constraints on the Development of Secondary Porosity in the Subsurface: Re-Evaluation of Processes. Marine and Petroleum Geology, 3, 243-255.

Giles, M.R. and de Boer, R.B. (1989) Secondary Porosity: Creation of Enhanced Porosities in the Subsurface from the Dissolution of Carbonate Cements as a Result of Cooling Formation Waters. Marine and Petroleum Geology, 6, 261-269.

Graham, R.H., Herbert, R., O'Leary, J., Piggott, N., Pulham, A. and Warron, E. (1997) Reservoir Evolution in the Piedemonte Llanero, Colombia (Abs.). VI Simposio Bolivariano, exploracion petrolera en las cuencas subandinas, Cartagena, Colombia, 15.

Gregg, J.M. and Shelton, K.L. (1990) Dolomitisation and Dolomite Neomorphism in the Back-Reef Facies of the Bonneterre and Davies formations (Cambrian), Southeastern Missouri. Jour. Sediment. Petrol., 60, 549-562.

Grelaud, S., Buil, S., Hardy, S. and Frizon de Lamotte, D. (2000) Trishear Kinematic Model of Fault-Propagation Folding and Sequential Development of Minor Structures: the Oupia Anticline (NE Pyrenees, France) Case Study. Bulletin de la Société Géologique de France, 171, 4, 441-449.

Grelaud, S., Sassi, W., Frizon de Lamotte, D., Jaswal, T. and Roure, F. (2002) Kinematics of Eastern Salt Range and South Potwar Basin (Pakistan): a New Scenario. Marine and Petroleum Geology, 19, 1127-1139.

Guilhaumou, N., Larroque, C., Nicot, E., Roure, F. and Stéphan, J.F. (1994) Mineralized Veins Resulting from Fluid Flow in Decollement Zones of the Sicilian Prism: Evidence from Fluid Inclusions. Bull. Soc. Géol. France, 165, 425-436.

Guilhaumou, N., Touray, J.C., Perthuisot, V. and Roure, F. (1996) Paleocirculation in the Basin of Southeastern France, SubAlpine Range: A Synthesis from Fluid Inclusions Studies. Marine and Petroleum Geology, 13, 6, 695-706.

Guilhaumou, N., Ellouz, N., Jaswall, T. and Mougin, P. (2000) Genesis and Evolution of Hydrocarbon Entrapped in Fluorite Deposits of Koh-i-Maran (North Kirthar Range, Pakistan). Marine and Petroleum Geology, 17, 1151-1164.

Guilhaumou, N., Benchilla, L., Mougin, P. and Dumas, P. (2004) Advances in Hydrocarbon Fluid Inclusion Microanalysis and PVT Modeling: Diagenetic History, P-T and Fluid Flow Reconstruction, a Case Study in the North Potwar Basin, Pakistan. In: Deformation, Fluid Flow and Reservoir Appraisal in Forland Fold-and-Thrust Belts, Swennen, R., Roure, F. and Granath, J. (eds.), AAPG Hedberg Mem., 1, in press.

Guiton, M.L.E. (2001) Contribution of Pervasive Fracture to the Deformation during Folding of Sedimentary Rocks. PhD Thesis, École polytechnique, Palaiseau, France.

Guiton, M.L.E., Sassi, W., Leroy, Y.M. and Gauthier, B.D.M. (2003a) Mechanical Constraints on the Chronology of Fracture Activation in Folded Devonian Sandstone of the Western Moroccan Anti-Atlas. Jour. of Structural Geology, 25, 13171330.

Guiton, M.L.E., Leroy, Y.M. and Sassi, W. (2003b) Activation of Diffuse Discontinuities and Folding of Sedimentary Layers. Jour. Geophysical Research, 108, B4, 2183, doi: 10.1029/2002JB001770.

Hanin, S. (2002) Thermoréduction des sulfates dans les réservoirs pétroliers : approche moléculaire. PhD Thesis, Univ. of Strasbourg.

Hardy, S.and Ford, M. (1997) Numerical Modeling of Thrishear Fault Propagation Folding. Tectonics, 16, 5, 841-854.

Harrison, W.J. and Thyne, G.D. (1991) Predictions of Diagenetic Reactions in the Presence of Organic Acids. Geochemica et Cosmochimica Acta, 56, 565-586. 
Haszeldine, R.S., Samson, I.M. and Cornford, C. (1984) Dating Diagenesis in a Petroleum Basin: a New Fluid Inclusion Method. Nature, 307, 354-357.

Henry, P. (2000) Fluid Flow at the Toe of the Barbados Accretionary Wedge Constrained by Thermal, Chemical and Hydrogeologic Observation and Model. Jour. Geophys. Res., 105, 25855-25872.

Henry, P., Lallemant, S.J., Le Pichon, X. and Lallemand, S.E. (1989) Fluid Venting along Japanese Trenches: Tectonic Context and Thermal Modeling. Tectonophysics, 160, 277-291.

Hutcheon, I., Shevalier, M. and Abercrombie, H.J. (1993) pH Buffering by Metastable Mineral-Fluid Equilibria and Evolution of Carbon Dioxide Fugacity during Burial Diagenesis. Geochimica et Cosmochimica Acta, 57, 1017-1027.

Hutcheon, I., Cody, J. and Yang, C. (2000) Fluid Flow in the Western Canada Sedimentary Basin - A Biased Perspective based on Geochemistry (Chapter 8). In: Fluids and Basin Evolution, Kyser K. (ed.), Short Course series, Mineralogical Association of Canada, 28, 197-224.

Krouse, H.R., Viau, C.A., Eliuk, L.S., Ueda, A. and Halas, S. (1988) Chemical and Isotopic Evidence of Thermochemical Sulphate Reduction by Light Hydrocarbon Gases in Deep Carbonate Reservoirs. Nature, 333, 415-419.

Larroque, C. (1993) L'accrétion tectonique de sédiments : modalités géométriques et cinématiques, paléo-circulations de fluides. PhD Thesis, University of Nice-Sophia Antipolis.

Larroque, C., Guilhaumou, N., Stéphan, J.F. and Roure, F. (1996) Large Scale Advection of Fluids at the Front of the Sicilian Neogene Subduction Complex. Tectonophysics, 254, 1-2, 41-56.

Leach, D.L. and Rowan, E.L. (1986) Genetic Link between Ouachita Foldbelt Tectonism and the Mississippi Valley-Type Lead-Zinc Deposits of the Ozarks. Geology, 14, 931-935.

Le Gallo, Y., Bildstein, O. and Brosse, E (1998) Modeling Diagenetic Changes in Reservoir Permeability, Porosity and Mineral Compositions with Water Flow. In: Reactive Transport Modeling of Natural Systems, Steefel, C (ed). Journal of Hydrology, 209, 366-388.

Léost, I. (1998) Reconstitution des mécanismes de transfert des fluides sur la marge ardéchoise en relation avec la structuration du bassin du sud-est, implications métallogéniques. PhD Thesis, University of Orléans.

Léost, I., Ramboz, C., Bril, H., Martin, P. and Hernandez, A. (1995) Reconstitution préliminaire T-t-X-s des paléocirculations de fluides dans les formations mésozoïques du forage de MorteMérie (marge ardéchoise, bassin sud-est de la France). C.R. Acad. Sci., Paris, 312, 845-852.

Léost, I., Renac, C., Ramboz, C. and Bril, H. (1998) Circulations hydrothermales diachrones et régimes de pression contrastés sur la marge ardéchoise de part et d'autre de la faille d'Uzer (forages de Balazuc et Morte-Mérie). Mise en évidence par l'étude des inclusions fluides dans leur contexte paléostructural. Bull. Soc. Géol. France.

Lewchuk, M.T., Al-Aasm, I.P., Symons, D.T.A. and Gillen, K.P. (1998) Dolomitization of Mississippian Carbonates in the Shell Waterton Gas Field, Southwestern Alberta: Insights from Paleomagnetism, Petrography and Geochemistry. Can. Soc. Petrol. Geol. Bull., 46, 387-410.

Lünenschloss, B., Bayer, U. and Muchez, P. (1997) Coalification Anomalies Induced by Fluid Flow at the Variscan thrust Front: A Numerical Model of the Palaeotemperature Field. Geol. Mijnbouw, 76, 3, 271-275.

Machel, H.G. (1987) Saddle Dolomite as a By-Product of Chemical Compaction and Thermochemical Sulfate Reduction. Geology, 15, 936-940.
Machel, H.G. (1990) Burial Diagenesis, Porosity and Permeability Development in Carbonates. In: The Development of Porosity in Carbonate Reservoirs, Bloy, G.R. and Hadley, M.G. (eds.), Canadian Society Petrol. Geol. Short Course Notes 2, 118.

Machel, H.G. (2001) Bacterial and Thermochemical Sulfate Reduction in Diagenetic Settings. Old and New Insights. Sedimentary Geology, 140, 143-175.

Machel, H.G., Krouse, H.R. and Sassen, R. (1995) Products and Distinguishing Criteria of Bacterial and Thermochemical Sulfate Reduction. Applied Geochemistry, 10, 373-389.

Machel, H.G., Cavell, P.A. and Patey, K.S. (1996) Isotopic Evidence for Carbonate Cementation and Recrystallization, and for Tectonic Expulsion of Fluids in the Western Canada Sedimentary Basin. Geol. Soc. America Bull., 108, 1108-1119.

Machel, H.G. and Cavell, P.A. (1999) Low-flux, TectonicallyInduced Squeegee Fluid Flow ("hot flash") into the Rocky Mountain Foreland Basin. Bulletin of Canadian Petroleum Geology, 47, 510-533.

Mercier, E., Outtani, F \& Frizon de Lamotte, D.(1997) The Late Evolution of Fault-Propagation Folds: Principles and Example. Journal of Structural Geology, 19, 8, 1107-1109.

Moore, J.C., Brown, K.M., Horath, F., Cochrane, G., MacKay, M. and Moore, G. (1991) Plumbing Accretionary Prisms: Effects of Permeability Variations. Philosophical Transactions of the Royal Society, A335, 275-288.

Mountjoy, E.W., Qing, H. and McNutt, R.H. (1992) Strontium Isotopic Composition of Devonian Dolomites, Western Canada Sedimentary Basin: Significance of Sources of Dolomitizing Fluids. Applied Geochemistry, 7, 59-75.

Muchez, Ph. and Sintubin, M. (2002) Palaeofluid Flow within the Evolution of Sedimentary Basins: Principles and Examples from the Carboniferous of Belgium. Aardk. Mededel., 12, 161-164.

Muchez, Ph., Marshall, J.D., Touret, J.L.R. and Viaene, W. (1994) Origin and Migration of Paleofluids in the Upper Visean of the Campine Basin, Northern Belgium. Sedimentology, 41, 133-145.

Muchez, Ph., Slobotnik, M., Viaene, W. and Keppens, E. (1995) Geochemical Constraints on the Origin and Migration of Palaeofluids at the Northern Margin of the Variscan Foreland, Southern Belgium. Sedimentary Geology, 96, 191-200.

Muchez Ph., Sintubin, M. and Swennen, R. (2000) Origin and Migration Pattern of Paleofluids during Orogeny: Discussion on the Variscides of Belgium and Northern France. Journal of Geochemical Exploration, 69-70, 47-51.

Muir Wood, R. (1994) Earthquakes, Strain-Cycling and the Mobilization of Fluids. In: Origin, Migration and Evolution of Fluids in Sedimentary Basins, Parnell, J. (ed.), Spec. Publ. Geol. Soc. London, 78, 85-98.

Nakal, S., Halliday, A.N., Kesler, S.E., Jones, H.D., Kyle, R.J. and Lane, T.S. (1993) Rb-Sr Dating of Sphalerites from Mississippi Valley-type (MVT) Ore Deposits. Geochimica and Cosmochimica Acta, 57, 417-427.

Nesbitt, B.E. and Muehlenbachs, K. (1994) Paleohydrology of the Canadian Rockies and Origin of Brines, $\mathrm{Pb}-\mathrm{Zn}$ Deposits and Dolomitization in the Western Sedimentary Basin. Geology, 22, 243-26.

Nielsen, P., Swennen, R. and Keppens, E. (1994) Multiple-Step Recrystallisation within Massive Ancient Dolomite Units: an Example from the Dinantian of Belgium. Sedimentology, 41, 567584.

Nielsen, P., Swennen, R., Muchez, Ph. and Keppens, E. (1998) Origin of Dinantian Zebra Dolomites South of the Brabant-Wales Massif, Belgium. Sedimentology, 45, 727-743. 
Nielsen, P., Swennen, R., Groessens, E., Muchez, P., Fallick, A.E., Keppens, E. and Weis, D. (in press) Columnar Calcites at the Boundary between Upper Tournaisian Dolomites and Limestones (Belgium): Multiple Origins for Apparently Similar Features. Sedimentology.

Oliver, J. (1986) Fluids Expelled Tectonically from Orogenic Belts: their Role in Hydrocarbon Migration and Other Geological Phenomena. Geology, 14, 99-102.

Orlov, A., Omelchenko, V., Trubenko, A. and Schneider, F. (2004) Incidence of Tectonic Stress and Disharmonic Folding on Secondary Fluid Migration and Overpressure Development in Ukrainian Basins. In: Deformation, Fluid Flow and Reservoir Appraisal in Forland Fold-and-Thrust Belts, Swennen, R., Roure, F. and Granath, J. (eds.), AAPG Hedberg Mem., 1, in press.

Orr, W.L. (1974) Changes in Sulfur Content and Isotopic Ratios of Sulfur during Petroleum Maturation. Study of Big Horn Basin Paleozoic Oilos. American Association of Petroleum Geologists Bulletin, 50, 2295-2318.

Ortuño-Arzate, S., Ferket, H., Cacas, M.C., Swennen, R. and Roure, F. (2003) Late Cretaceous Carbonate Reservoirs in the Cordoba Platform and Veracruz Basin (Eastern Mexico). In: The Circum-Gulf of Mexico and the Caribbean: Hydrocarbon Habitats, Basin Formation and Plate Tectonics, Bartolini, C., Buffler, R.T. and Blickwede, J.F. (eds.), AAPG Mem., 79, Ch. 22, 476-514.

Packard, J., Pellegrin, G.J., Al-Aasm, I.S., Samson, I. and Gagnon, J. (1990) Diagenesis and Dolomitization Associated with Hydrothermal Karst in Famenian Upper Wabamum Ramp Sediments, Northwestern Alberta. In: The Development of Porosity in Carbonate Reservoirs, Bloy, G. and Hadley, M. (eds.), Canadian Society of Petroleum Geology Short Course, 9.1-9.27.

Pagel, M., Pichon, R., Hernandez, E., Roure, F. and Schneider, F. (2005) Source of Silica and Timing of Quartz Cementation in the Cretaceous Reservoirs in the Foothills of Eastern Venezuela. Journal of Sedimentary Research, in press.

Pierre, C. and Rouchy, J.M. (1988) Carbonate Replacements after Sulfate Evaporites in the Middle Miocene of Egypt. Journal of Sedimentary Petrology, 58, 3, 446-456.

Qing, H. and Mountjoy, E.W. (1995) Paleohydrology of the Canadian Rockies and Origins of Brines, $\mathrm{Pb}-\mathrm{Zn}$ Deposits and Dolomitization in the Western Canada Sedimentary Basin: Comment. Geology, 23, 189-190.

Railsback, L.B. (1993) Contrasting Styles of Chemical Compaction in the Upper Pennsylvanian Dennis Limestone in the Midcontinent Region, USA. Jour. Sedimentary Petrology, 63, 6172.

Ramboz, C., Choi, C.G., Volfinger, M., Leost, I. (1999) Hydrothermal Dolomitization of Triassic Evaporites on the W Margin of the SE Basin of France: A Record of the Seismogenic Activity of the Uzer Growth Fault at the Mesozoic. EUG 10, Abs. Strasbourg.

Renard, F., Ortoleva, P. and Gratier, J.P. (1997) PressureSolution in Sandstones: Influence of Clays and Dependance on Temperature and Stress. Tectonophysics, 280, 257-266.

Robinson, A. and Gluyas, J. (1992) Duration of Quartz Cementation in Sandstones, North Sea and Haltenbanken Basins. Marine and Petroleum Geol., 9, 324-327.

Robion, Ph., Frizon de Lamotte, D. and Aubourg, C. (1997) Magnetic Fabric Analysis and Deformation of Sandstone Reservoirs. In: Toro, J. et al., SUBTRAP Colombian Report, IFP/SUBTRAP Report 44557.

Robion, Ph., Faure, J.L., Swennen, R. and Frizon de Lamotte, D. (2002) Relationship between Late Cretaceous Chemical Remagnetization and Acquisition of Tectonic Magnetic Fabric in Paleozoic Carbonate Rocks from Eastern Canadian Cordillera. In:
Deformation, Fluid Flow and Reservoir Appraisal in Foreland Fold-and-Thrust Belts, Roure, F. and Swennen, R. (convenors), AAPG-IFP Hedberg Conference, May 14-18, Palermo, 44.

Robion, Ph., Faure, J.L. and Swennen, R. (2004) Late Cretaceous Chemical Remagnetization of the Paleozoic Carbonates from the Undeformed Foreland of the Western Canadian Cordillera. In: Deformation, Fluid Flow and Reservoir Appraisal in Foreland Fold-and-Thrust Belts, Swennen, R., Roure, F. and Granath, J. (eds.), AAPG Hedberg Mem., 1, in press.

Roure, F. and Sassi, W. (1995) Kinematics of Deformation and Petroleum System Appraisal in Neogene Foreland Fold-andThrust Belts. Petroleum Geosciences, 1, 253-269.

Roure, F. and Swennen, R., Convenors (2002) Deformation, Fluid Flow and Reservoir Appraisal in Foreland Fold-and-Thrust Belts. AAPG-IFP Hedberg Conference, Abstract volume, 14-18 May 2002, Palermo, Sicily.

Roure, F., Casero, P. and Vially, R. (1991) Growth Processes and Mélange Formation in the Southern Apennines Accretionary Wedge. Earth and Planetary Sciences Letters, 102, 395-412.

Roure, F., Carnevali, J.O., Gou, Y. and Subieta, T. (1994) Geometry and Kinematics of the North Monagas thrust Belt (Venezuela). Marine and Petroleum Geology, 11, 347-362.

Roure, F., Bordas-Lefloch, N., Toro, J., Aubourg, C., Guilhaumou, N., Hernandez, E., Lecornec-Lance, S., Rivero, C., Robion, Ph. and Sassi, W. (2003) Petroleum Systems and Reservoir Appraisal in the Sub-Andean Basins (Eastern Venezuela and Eastern Colombia Foothills). In: The Circum-Gulf of Mexico and the Caribbean: Hydrocarbon Habitats, Basin Formation and Plate Tectonics, Bartolini, C., Buffler, R.T. and Blickwede, J.F. (eds.), AAPG Mem., 79, Ch. 34, 750-775.

Roure, F., Fili, I., Nazaj, S., Cadet, J.P., Mushka, K. and Bonneau, M. (2004) Kinematic Evolution and Petroleum Systems: an Appraisal of the Outer Albanides. In: Thrust Tectonics and Hydrocarbon Systems, McClay, K.R. (ed.), AAPG Mem., 82, 474-493.

Saint-Bezar, B., Frizon de Lamotte, D., Morel, J.L. and Mercier, E. (1998) Kinematics of Large Scale Tip Line Folds from the High Atlas Thrust Belt (Morocco). Journal of Structural Geology, 20, 8, 999-1011.

Sans, M., Vergés, J., Gomis, E., Parés, J.M., Schiatarella, M., Travé, A., Calvet, F., Santanach, P. and Doulcet, A. (2003) Layer Parallel Shortening in Salt-Detached Folds: Constraints on CrossSection Restoration. Tectonophysics, 372, 85-104.

Sassi, W. and Faure, J.L. (1996) Role of Faults and Layer Interfaces on the Spatial Variation of Stress. Tectonophysics, 266, 101-119.

Schmidt, V. and MacDonald, D.A. (1979) The Role of Secondary Porosity in the Course of Sandstone Diagenesis. In: Aspects of Diagenesis, Scholle, P.A. and Schluger, P.R. (eds.), SEPM Spec. Publ., 26, 157-207.

Schneider, F. (2003) Basin Modeling in Complex Area: Examples from Eastern Venezuelan and Canadian Foothills. Oil \& Gas Science and Technology, Revue de l'IFP, 58, 2, 313-324.

Schneider, F., Devoitine, H., Faille, I., Flauraud, E. and Willien, F. (2002) Ceres 2D: A numerical Prototype for HC Potential Evaluation in Complex Area. Oil \& Gas Science and Technology, Revue de l'IFP, 54, 6, 607-619.

Schneider, F., Pagel, M. and Hernandez, E. (2004) Basin Modeling in Complex Area: Example from the Eastern Venezuelan Foothills. In: Deformation, Fluid Flow and Reservoir Appraisal in Forland Fold-and-Thrust Belts, Swennen, R., Roure, F. and Granath, J. (eds.), AAPG Hedberg Mem., 1, in press.

Simpson, D.W. and Richards, P.G. (eds) (1981) Earthquake Prediction: an International Review, American Geophysical Union, Maurice Ewing Series, 4, 593-603. 
Smith, T.M. and Dorobek, S.L. (1993) Alteration of EarlyFormed Dolomite during Shallow to Deep Burial: Mississippian Mission Canyon Formation, Central to Southwestern Montana. Geol. Soc. of America Bull., 105, 1389-1399.

Sun, W., Jackson, M. and Craddock, J.P. (1993) Relationship between Remagnetization, Magnetic Fabric and Deformation in Paleozoic Carbonates. Tectonophysics, 221, 361-366.

Surdam, R.C., Boese, S.W. and Crossey, L.J. (1984) The Chemistry of Secondary Porosity. In: Clastic Diagenesis, McDonald, D.A. and Surdam, R.C. (eds.), AAPG Memoir 37, 127-149.

Swennen, R., Faure, J.L., Osadetz, K., Robion, Ph. and Roure, F. (2002) Mesodolomite Formation as a Result of Layer Parallel Shortening and Secondary Porosity Development by Cooling of Formation Waters or Cooling Due to Thrust Emplacement: An Example from the Canadian Foreland Fold-and-Thrust Belt. In: Deformation, Fluid Flow Reconstruction and Reservoir Appraisal in Foreland Fold-and-Thrust Belts, Roure, F. and Swennen, R. (convenors), AAPG-IFP Hedberg Conference, May 14-18, 2002, Palermo-Mondello, Sicily, Italy, Abst.

Swennen, R., Ferket, H., Benchilla, L., Roure, F., Ellam, R. and SUBTRAP Team (2003a) Fluid Flow and Diagenesis in Carbonate Dominated Foreland Fold-and-Thrust Belts: Petrographic Inferences from Field Studies of Late-Diagenetic Fabrics from Albania, Belgium, Canada, Mexico and Pakistan. Journal of Geochemical Exploration, 78-79, 481-485.

Swennen, R., Vandeginste, V. and Ellam, R. (2003b) Genesis of Zebra Dolomites (Cathedral Formation: Canadian Cordillera Fold and Thrust Belt, British Columbia). Jour. Geochem. Explor., 7879, 571-577.

Swennen, R., Roure, F. and Granath, J., eds. (2004) Deformation, Fluid Flow and Reservoir Appraisal in Foreland Fold-and-Thrust Belts. Post-Hedberg Proceedings, AAPG Hedberg Memoir, 1, in press.

Symons, D.T.A., Lewchuk, M.T. and Sangster, D.F. (1998) Laramide Orogenic Fluid Flow into the Western Canada Sedimentary Basin: Evidence from Paleomagnetic dating of the Kicking Horse Mississippi Valley-Type Ore Deposit. Economic Geology, 93, 68-83.

Symons, D.T.A., Enkin, R.J. and, Cioppa, M.T. (1999) Paleomagnetism in the Western Canada Sedimentary Basin: Dating Fluid Flow and Deformation. Bulletin of Canadian Petroleum Geology, 47, 4, 524-547.

Toro, J., Roure, F., Bordas-Lefloch, N., Le Cornec-Lance, S. and Sassi, W. (2004) Thermal and Kinematic Evolution of the Eastern Cordillera Fold-and-Thrust Belt, Colombia. In: Deformation, Fluid Flow and Reservoir Appraisal in Forland Fold-and-Thrust Belts, Swennen, R., Roure, F. and Granath, J. (eds.), AAPG Hedberg Mem., 1, 79-115.

Travé, A., Labaume, P., Calvet, F., Soler, A., Tritlla, J., Buatier, M., Potdevin, J.L., Séguret, M., Raynaud, S. and Briqueu, L. (1998) Fluid Migration During Eocene Thrust Emplacement in the South Pyrenees Foreland Basin (Spain): an Integrated Structural, Mineralogical and Geochemical Approach. In: Cenozoic Foreland Basins of Western Europe, Mascle, A., Puigdefabregas, C.,
Luterbacher, H.P. and Fernandez, M. (eds.), Geol. Soc. of London, Special Publ., 134, 163-188.

Travé, A., Calvet, F., Sans, M., Verges, J. and Thirlwall, M. (2000) Fluid History Related to the Alpine Compression at the Margin of the South Pyrenean Foreland Basin; the El Guix Anticline. Tectonophysics, 321, 1, 73-102.

Travé, A., Calvet, F., Salas, R. and Roca, E. (2004) Fluid Flow during Paleogene Compression in the Linking Zone Fold and Thrust Belt (NE Spain). In: Deformation, Fluid Flow and Reservoir Appraisal in Forland Fold-and-Thrust Belts, Swennen, R., Roure, F. and Granath, J. (eds.), AAPG Hedberg Mem., 1, in press.

Vandeginste, V., Swennen, R., Ellam, R. and Schneider, F. (2004) Zebra Dolomitization as a Result of Focussed Fluid Flow during Fold-and-Thrust Belt Development (Middle Cambrian, Canadian Rocky Mountains). Sedimentology, in press.

Van Geet, M., Swennen, R., Durmishi, C., Roure, F. and Muchez, $\mathrm{Ph}$. (2002) Paragenesis of Cretaceous to Eocene Carbonate reservoirs in the Ionian Foreland Fold-and-Thrust Belt (Albania): Relation between Tectonism and Fluid Flow. Sedimentology, 49, 697-718.

Walderhaug, O. (1996) Kinetic Modeling of Quartz Cementation and Porosity Loss in Deeply Buried Sandstone Reservoirs. AAPG Bull., 80, 731-745.

Warren, E.A., O'Leary, J., Herbert, R., Pulham, A.J., Graham, R. and Bonnell, L. (1998) Porosity Prediction for Deeply-Buried quartz arenites in the Llanos foothills, Eastern Cordillera, Colombia (Abs.). AAPG Regional Meeting, Rio de Janeiro, Brazil, 536-537.

Warren, E.A. and Pulham, A.J. (2001) Anomalous Porosity and Permeability Preservation in Deeply Buried Tertiary and Mesozoic Sandstones in the Cusiana Field, llanos foothills, Colombia. Journal of Sedimentary Research, 71, 1, 2-14.

Wendte, J., Qing, H., Dravis, J.J., Moore, S.L.O., Stasiuk, L.D. and Ward, G. (1998) High-Temperature Saline (Thermoflux) Dolomitization of Devonian Swan Hills Platform and Bank Carbonates, Wild River Area, West-Central Alberta. Bull. of Canadian Petroleum Geology, 46, 210-265.

Worden, R.H., Warren, E.A., Smalley, P.C., Primmer, T.J., Oxtoby, N.H., Osborne, M. and Haszeldine, R.S. (1995) Discussion of "Evidence for Resetting of Fluid Inclusion Temperatures from Quartz Cements in Oilfields" by Osborne and Haszeldine and Reply. Marine and Petroleum Geology, 12, 566575.

Yao, Q. and Demicco, R.V. (1995) Paleoflow Patterns of Dolomitizing Fluids and Paleohydrology of the Southern Canadian Rocky Mountains: Evidence from Dolomite Geometry and Numerical Modeling. Geology, 23, 791-794.

Yao, Q. and Demicco, R.V. (1997) Dolomitization of the Cambrian Carbonate Platform, Southern Canadian Rocky Mountains: Dolomite Front Geometry, Fluid Inclusion Geometry, Isotopic Signature, and Hydrogeologic Modeling Studies. American Journal of Science, 297, 892-938.

Final manuscript received in November 2004 or distributed for profit or commercial advantage and that copies bear this notice and the full citation on the first page. Copyrights for components of this work owned by others than IFP must be honored. Abstracting with credit is permitted. To copy otherwise, to republish, to post on servers, or to redistribute to lists, requires prior specific permission and/or a fee: Request permission from Documentation, Institut français du pétrole, fax. +33147527078 , or revueogst@ifp.fr. 